\title{
Az Aspergillus nemzetség átfogó filogenetikai analízise; potenciális mikotoxin-termelő és opportunista patogén fekete Aspergillus törzsek jellemzése
}

Doktori értekezés

Szigeti Gyöngyi

Témavezetö:

Prof. Dr. Varga János

Egyetemi tanár

Biológia Doktori Iskola

\section{SZEGEDI TUDOMÁNYEGYETEM}

Természettudományi és Informatikai Kar

Mikrobiológiai Tanszék

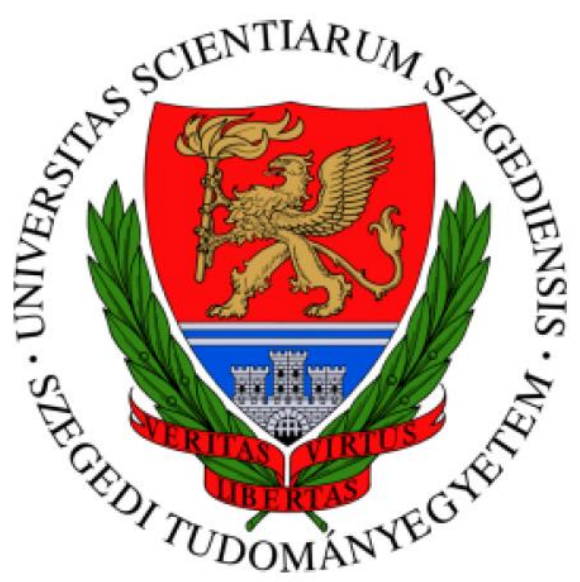

SZEGED

2018 


\section{Tartalomjegyzék}

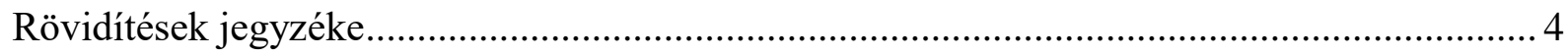

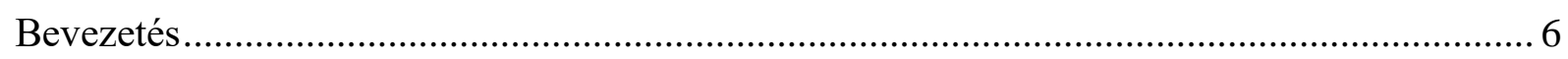

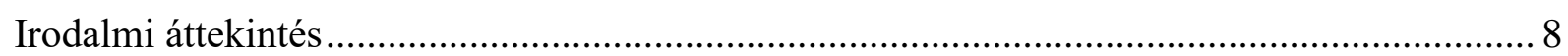

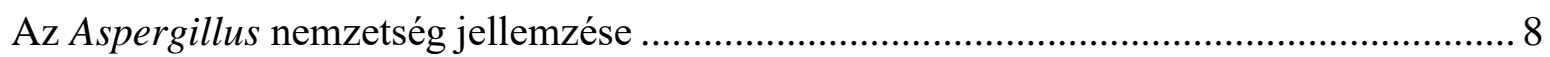

Fekete Aspergillus-ok jellemzése, taxonómiai helyzetük .................................................. 11

Az A. niger és A. welwitscheae testvérfajok közötti különbségek ..................................... 17

Fekete Aspergillus-ok, mint humán patogének ........................................................... 17

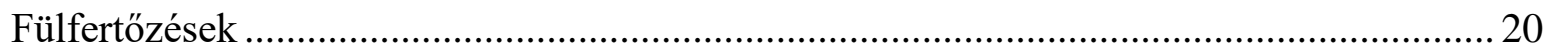

Fekete Aspergillus fajok mikotoxintermelö képessége .................................................... 20

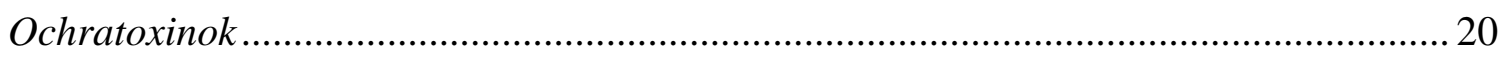

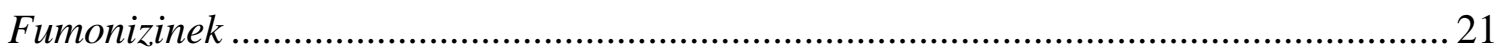

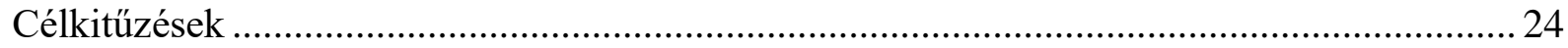

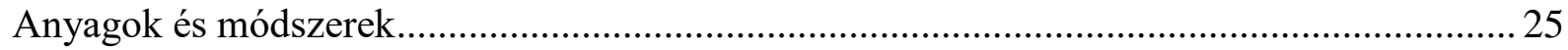

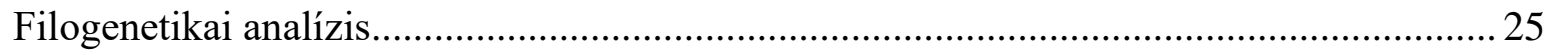

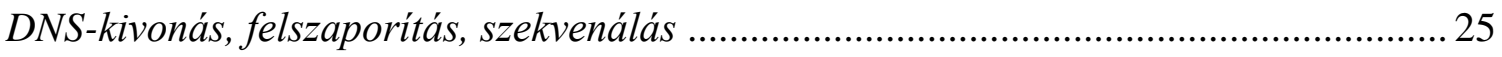

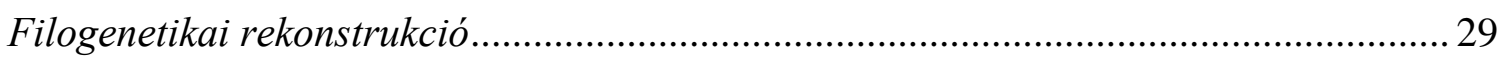

Az A. niger és az A. welwitscheae testvérfajok közötti különbségek vizsgálata ................. 29

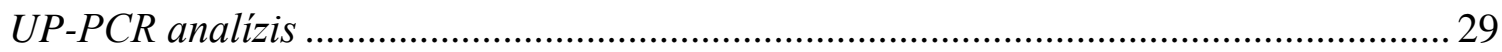

Fülfertőzésekből származó fekete Aspergillus izolátumok vizsgálata ............................... 30

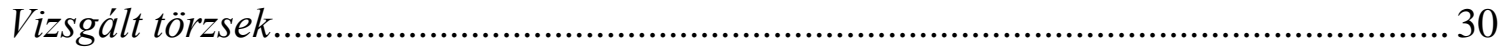

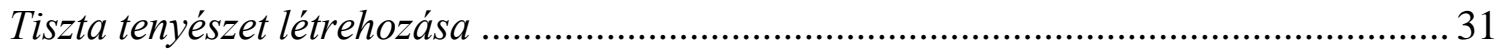

A micélium felszaporitása, DNS izolálás .................................................................. 31

Az izolátumok molekuláris azonosítása kalmodulin szekvenciák alapján ....................... 31

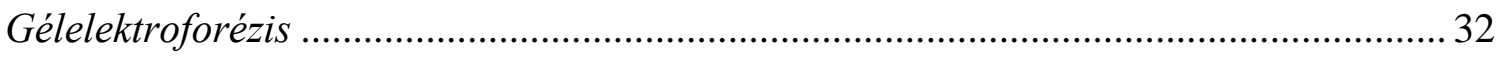

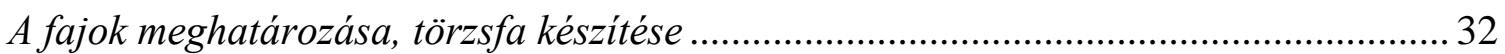

Fülfertözésekböl származó fekete Aspergillus izolátumok antifungális szerekkel szembeni

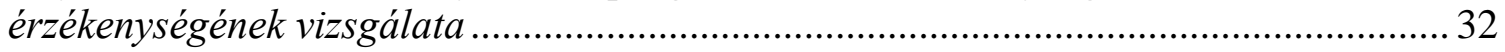

Élelmiszereken előforduló fekete Aspergillus izolátumok.................................................. 33

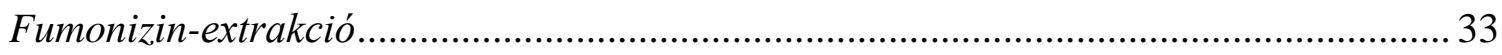

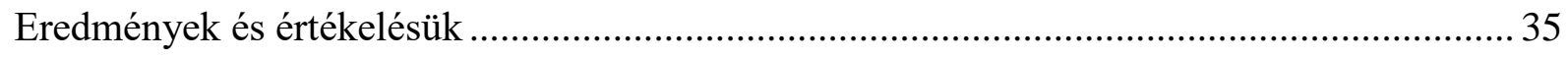

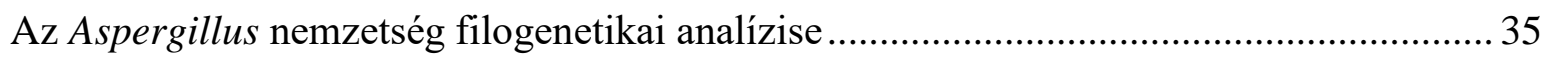

Az A. niger és A. welwitschiae fajok közötti különbség kimutatása UP-PCR analízissel ... 46

Fekete Aspergillus-ok, mint opportunista humán patogének .......................................... 47

Fülfertözésekből származó fekete Aspergillus izolátumok fajszintü azonositása ............. 47

Fülfertözésekböl származó fekete Aspergillus izolátumok antifungális szerekkel szembeni érzékenysége..... 
Fekete Aspergillus-ok, mint potenciális fumonizintermelök elöfordulása élelmiszerekben 52

Fekete Aspergillus-ok előfordulása és eloszlása mazsolamintákon ................................ 52

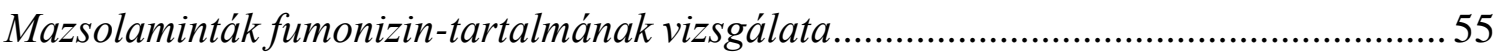

Mazsoláról származó fekete Aspergillus izolátumok fumonizintermelő képessége ..........55

Fekete Aspergillus izolátumok fügéről és datolyáról ......................................................59

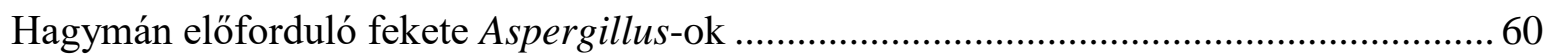

Hagymáról izolált A. welwitschiae törzsek mikotoxintermelö képessége ....................... 63

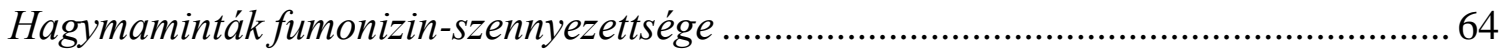

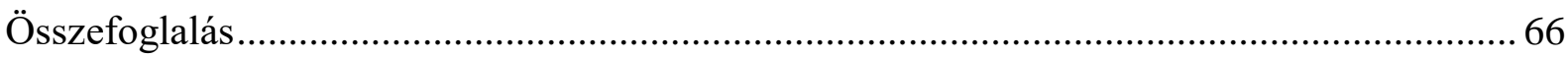

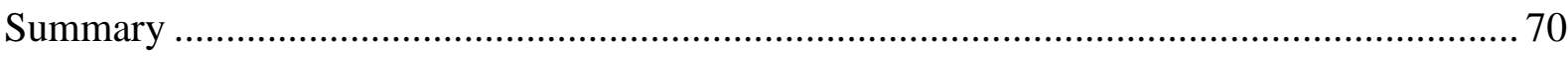

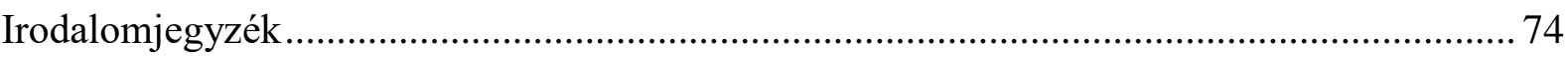

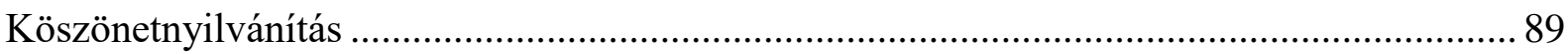




\section{Rövidítések jegyzéke}

AAL toxinok: Alternaria alternata által termelt toxinok

Acl: ATP citrát liáz

AFLP: Amplified Fragment Length Polymorphism (Felsokszorozott fragmentumhosszpolimorfizmus)

ATCC: American Type Culture Collection (Amerikai Típustörzs-gyüjtemény)

CBS: Centraalbureau voor Schimmelcultures, Utrecht, Hollandia

Cct8: chaperonin containing TCP1 subunit (dajkafehérjét kódoló lókusz)

CLSI: Clinical \& Laboratory Standards Institute

cmd: kalmodulin

CREA: Creatine sucrose agar (kreatin-szacharóz agar)

CYA20S: Czapek Yeast Autolysate Agar 20\% szacharózzal

DRBC: Dichloran Rose-Bengal Chloramphenicol Agar

FB: Fumonizin B

GTR: General Time Reversible model

IARC: International Agency for Research on Cancer (Nemzetközi Rákkutatási Ügynökség)

IGS: Intergenic Spacer, gének közötti elválasztó régió

ITS: Internal Transcribed Spacer, köztes átíródó elválasztó régió

MCM7: Mini-chromosome maintenance complex component 7 (minikromoszómák fenntartásáért felelős komplex 7-es komponense)

MEA: Malt Extract Agar (malátakivonatos agar)

MEC: Minimum Effective Concentration (Minimális hatékony koncentráció)

MIC: Minimum Inhibitory Concentration (Minimális gátlási koncentráció)

ML: Maximum Likelihood

OD: Optikai Denzitás

OTA: Ochratoxin A

PCR: Polymerase Chain Reaction (Polimeráz láncreakció)

pel $(A, B)$ : pektin-liáz gének

pki: piruvát-kináz gén

RAPD: Random Amplified Polymorphic DNA (Random felsokszorozódó polimorf DNS)

RFLP: Restriction Fragment Length Polymorphism (Restrikciós fragmentumhosszpolimorfizmus) 
RPB1, RPB2: RNA Polymerase II largest and second largest subunit (RNS polimeráz II legnagyobb és második legnagyobb alegysége)

RP-HPLC/ESI-IT-MS ${ }^{2}$ : Reversed-Phase High-Performance Liquid Chromatography with Electrospray Ionization Ion Trap tandem Mass Spectrometry

RPMI: Roswell Park Memorial Institute

TAE: Trisz-ecetsav-dinátrium-EDTA

TEF1: transzlációs elongációs faktor $1 \alpha$

Tsr1: 20S rRNS összeszerelésében szerepet játszó fehérjét kódoló lókusz

UP-PCR: Universally Primed Polymerase Chain Reaction (Univerzálisan bekötődő polimeráz láncreakció)

YPD: Yeast extract Pepton Dextrose tápközeg 


\section{Bevezetés}

Az Aspergillus nemzetség a fonalasgombák egy nagyon változatos csoportját foglalja magába. Az ide tartozó fajok között találunk olyanokat, amelyek biotechnológiai és élelmiszeripari alkalmazásuknak köszönhetően igen nagy gazdasági jelentőséggel rendelkeznek. Az egész Aspergillus nemzetségre vonatkozóan elmondható, hogy az egymással közeli rokonságban álló fajok morfológiai karakterek alapján történő elkülönítése igen nehéz, néhány esetben nem is lehetséges. Bizonyos genomi szekvenciák azonban alkalmasak arra, hogy ezeket a fajokat elkülönítsük egymástól, mint például a kalmodulin és $\beta$-tubulin gének szekvenciái. Bár filogenetikai munkák sora enged betekintést az Aspergillus fajok közötti rokonsági kapcsolatokba, még mindig vannak megválaszolatlan kérdések. A korábbi munkák általában valamelyik alcsoportra (szekcióra, alnemzetségre) fókuszálnak, nemzetségszintű filogenetikai vizsgálatra eddig kevés esetben volt példa, így a rokonsági kapcsolatok pontos feltérképezése még nem történt meg (Samson és mtsai. 2014).

A rokonsági kapcsolatok megismerésének érdekében filogenetikai vizsgálatot végeztünk 93 faj bevonásával. A fajokat úgy választottuk ki, hogy a teljes Aspergillus nemzetséget reprezentálják. Az elemzéshez 6 génszakaszt választottunk ki. Az RPB1 és RPB2 (RNS polimeráz alegységei), a Tsr1 (20S rRNS összeszerelésében játszik szerepet), illetve a Cct8 (dajkafehérje) lókuszok Houbraken és Samson (2011) munkája alapján alkalmasnak bizonyultak az alnemzetség-szintü rokonsági kapcsolatok megállapítására a Penicillium nemzetségen belül, ezért ígéretesnek bizonyultak a filogenetikailag közel álló Aspergillus nemzetség esetén is. A vizsgálatba ezen kívül bevontuk még az Acll (ATP citrát-liáz) és MCM7 (minikromoszómák fenntartásáért felelős) lókuszokat is.

Az Aspergillus nemzetség Nigri szekciójába tartozó fajokat fekete Aspergillus-oknak nevezzük (Gams és mtsai. 1985). Legismertebb képviselőjük az Aspergillus niger, melyet széles körben alkalmaznak az élelmiszeriparban citromsav és glükonsav termeltetésére, továbbá számos enzim, pl. pektináz, amiláz előállítására is használják (Varga és mtsai. 2000). A fekete Aspergillus-ok humán betegségek okozói is lehetnek, valamint egyes fajok gyakran élelmiszereinket is szennyezhetik különböző mikotoxinok (ochratoxinok, fumonizinek) termelése révén, melyek az állatokra és emberekre egyaránt káros hatást fejtenek ki.

A fumonizinek karcinogén mikotoxinok, melyeket Fusarium verticillioides-ben (Gibberella moniliformis) azonosítottak először (Gelderblom és mtsai. 1988). Hatásuk egyrészt 
abban nyilvánul meg, hogy gátolják a szfingolipid bioszinézist. Ennek oka, hogy szerkezetük hasonló a szfingolipid intermedierekéhez, és a ceramid szintáz enzimhez kapcsolódnak. (Wang és mtsai. 1991). Ezen kívül gátolják a folsavtranszportot is, melynek következtében a gerincvelőcső záródása nem lesz teljes az embrióban (Varga és mtsai. 2009b). Továbbá ezek a toxinok tehetők felelőssé különböző, haszonállatainkat érintő megbetegedésért, mint például lovak agylágyulásáért (Marasas és mtsai. 1988b), valamint sertések tüdőödémájáért is (Haschek és mtsai. 2001). A fekete Aspergillus-ok lehetséges fumonizin-termelése azért jelentős, mert sok élelmiszer- és takarmánynövényen elöfordulnak, így azok fumonizint tartalmazhatnak.

Különböző mezőgazdasági termékekről gyüjtöttünk fekete Aspergillus izolátumokat, melyeket fajszinten meghatároztunk. Azonosításukhoz a kalmodulin gén egy szakaszának szekvenciáit használtuk. Vizsgáltuk az izolátumok fumonizintermelő képességét, valamint az adott termékek fumonizintartalmát is. Mazsola-, datolya-, füge- és hagymamintákról számos fekete Aspergillus törzset sikerült izolálnunk.

A fekete Aspergillus-okat ugyan opportunista patogénként tartjuk számon, azonban a modern immunszupresszáns terápiák elterjedésével az utóbbi években megnőtt az áltluk okozott fertőzéseknek a száma és jelentősége (Cohen és mtsai. 1993). A fertőzés leggyakrabban a légzőszervrendszerben jelentkezik, de szemfertőzést (keratitisz) és fülfertőzést (otitisz) is okozhatnak. Humán fertőzések esetén a kórokozó pontos, fajszintű meghatározása rendkívül fontos, mert a különböző fajok eltérő mértékben lehetnek érzékenyek különböző antifungális szerekkel szemben (Balajee és mtsai. 2005). A gyakorlatban a fekete Aspergillus fajokat általában A. niger-ként azonosítják morfológiai alapon, pedig más közeli rokon fajok is okozhatnak fertőzéseket.

Iráni és magyarországi fülfertőzésből származó izolátumokat azonosítottunk a kalmodulin gén egy szakaszának bázissorrendje alapján. A vizsgált izolátumokat kivétel nélkül A. niger-ként határozták meg morfológiai karakterek figyelembevételével. Teszteltük továbbá néhány izolátum érzékenységét a klinikumban széles körben használt gombaellenes szerekkel szemben. 


\section{Irodalmi áttekintés}

\section{Az Aspergillus nemzetség jellemzése}

Az Aspergillus nemzetség a fonalasgombák egy nagyon változatos csoportját foglalja magába, mely gazdaságilag is nagy jelentőséggel rendelkezik. A nemzetség (a Penicillium nemzetséggel együtt) az Ascomycota törzs Eurotiomycetes osztályának Eurotiales rendjén belül az Aspergillaceae családba tartozik (Houbraken és Samson 2011). A nemzetségbe sorolt, elsősorban szaprofita törzsek a világ minden táján, a legkülönbözőbb élőhelyeken előfordulnak. A csoport egyes képviselői igen jelentősek biotechnológiai eljárásokban történő alkalmazásuk miatt. Különféle metabolitokat termeltetnek velük, továbbá élelmiszer-fermentációkban történő alkalmazásuk is igen elterjedt. Ezen kívül ismertek, mint növények kártevői, élelmiszerszennyezők, mikotoxintermelők, valamint opportunista patogénként állati és emberi megbetegedéseket is okozhatnak. A nemzetségbe tartozó fajok osztályozása és azonosítása korábban morfológiai bélyegek alapján történt, az utóbbi évtizedekben azonban megnőtt a molekuláris karakterek vizsgálatának jelentősége, így napjainkban a fajmeghatározás egyre inkább molekuláris különbségeken alapul.

Az Aspergillus elnevezés Pier Antonio Micheli olasz botanikus nevéhez köthető (Micheli 1729). Katolikus pap lévén, az ide tartozó gombák konídiumtartói a liturgiában használatos szenteltvíz-szóróra (aspergillum) emlékeztették. Később Albrecht von Haller (1768), majd Elias Magnus Fries (1832) is elismerték és megerősítették az Aspergillus nemzetség létét. Az ide tartozó teleomorf fajokat tizenegy nemzetségbe sorolták (Frisvad és Samson 2000; Udagawa és Uchiyama 2002): Eurotium, Chaetosartorya, Emericella, Fennellia, Hemicarpenteles (a közelmúltban végzett vizsgálat alapján a legtöbb korábban ide sorolt faj a Penicillium nemzetséghez tartozik (Visagie és mtsai. 2014a)), Neosartorya, Petromyces, Sclerocleista (Houbraken és Samson (2011) munkája alapján nem tartozik az Aspergillus nemzetséghez), Stilbothamnium, Neopetromyces és Neocarpenteles. Aspergillus monográfia Thom és Raper (1945), majd Raper és Fennell (1965) munkája nyomán jelent meg 89, illetve 150 leírt fajjal. Felismerve azt, hogy a taxonómiának szükségtelen és indokolatlan az azonos fajhoz tartozó anamorf és teleomorf törzseket külön névvel ellátnia, sőt éppen az egyszerüségre kellene, hogy törekedjen, figyelmen kívül hagyták a teleomorf fajok eltérö elnevezését, ellentétben az uralkodó nevezéktannal, és kizárólag az Aspergillus nevet használták. Ennek ellenére a kettős elnevezés mégis népszerü lett, és használata széles körben elterjedt a gombataxonómiában. Pitt és mtsai. (2000) egy jóval későbbi munkában 184 Aspergillus, és 70 ide 
tartozó teleomorf fajnevet közöltek. Az említett munkákban a fajok azonosítása morfológiai karakterek alapján történt. A későbbiekben a morfológián alapuló fajkoncepciót egyre inkább a polifázikus fajkoncepció váltotta fel, melyben a morfológiai tulajdonságok mellett fiziológiai, és főként filogenetikai karakterek is meghatározóvá váltak a fajok elkülönítésében, így a fenti munkákban közölt fajlisták hamarosan idejétmúlttá váltak (Samson és mtsai. 2007). Egyre több új faj került leírásra, ami főleg arra bezethető vissza, hogy sok esetben a morfológiai karakterek alapján azonos fajhoz sorolt törzsek között a filogenetikai vizsgálatok egyértelmü különbségeket tártak fel. Jelenleg megközelítőleg 350 fajt sorolhatunk a nemzetségbe (Samson és mtsai. 2014). Korábban a nemzetségen belüli osztályozás is morfológiai eltéréseken alapult. Raper és Fennell (1965) a nemzetséget 18 csoportra osztotta, nevezéktani státuszok nélkül. Később Gams és mtsai. (1985) az ide tartozó fajokat alnemzetségekbe és szekciókba sorolták, csoportosításuk a filogenetikai karakterek alapján történő csoportosítással nagymértékü egyezést mutatott. Peterson (2008) négy lókusz vizsgálata alapján 5 alnemzetséget és 16 szekciót különített el. Houbraken és munkatársai (2014), valamint Hubka és munkatársai (2015) a nemzetség négy alnemzetségbe (Aspergillus, Circumdati, Fumigati, Nidulantes) és 20 szekcióba történő besorolását javasolták. Bár korábbi filogenetikai munkák sora engedett betekintést az Aspergillus fajok közötti rokonsági kapcsolatokba (Berbee és mtsai. 1995; Ogawa és mtsai. 1997; Tamura és mtsai. 2000; Geiser és mtsai. 2008; Peterson 2008; Peterson és mtsai. 2008; Houbraken és Samson 2011), még mindig vannak megválaszolatlan kérdések. Az eddigi munkák általában valamelyik alcsoportra (szekcióra, alnemzetségre) fókuszáltak, nemzetségszintű filogenetikai vizsgálatra eddig kevés esetben volt példa, így a rokonsági kapcsolatok pontos feltérképezése még nem történt meg (Samson és mtsai. 2014). A filogenetikai vizsgálatok a gomba-taxonómiában jelentős változásokat hoztak. Azon törekvés értelmében, hogy egy gombafaj ivartalan és ivaros alakja csak egy névvel rendelkezzen (Taylor 2011; McNeill és Turland 2011), fontos a nemzetségen belüli rokonsági kapcsolatok pontos feltérképezése. Az Aspergillus nemzetség tagjai fontos szerepet játszanak biotechnológiai, ipari és klinikai területeken egyaránt. Éppen ezért a nem megfelelő taxonómia és bizonytalan névhasználat rengeteg félreértéshez vezethet. Több korábbi tanulmány is alátámasztja az Aspergillus nemzetség monofiletikus voltát (Berbee és mtsai. 1995; Ogawa és mtsai. 1997; Tamura és mtsai. 2000). Peterson (2008) 5.8S rDNS, 28S rDNS és RPB2 génszekvenciákon alapuló munkájában a nemzetség 3 fó kládra különült el, de a kládok közötti kapcsolat statisztikailag nem volt magasan támogatott. Ezek a kládok egyezést mutattak a nemzetség alnemzetségeivel: egy klád a Circumdati és Fumigati alnemzetségeket foglalta magába, egy a Nidulantes alnemzetséget reprezentálta, egy pedig az Aspergillus alnemzetség tagjait 
tartalmazta. Geiser és munkatársai (2008) 10 génen alapuló filogenetikai munkájában a nemzetség tagjai szintén három kládra oszlanak szét: a Circumdati, Fumigati és Nidulantes alnemzetségekre. Az Aspergillus alnemzetségbe sorolt törzseket ebbe a munkába nem vonták be. Houbraken és Samson (2011) négy génen alapuló filogenetikai vizsgálatot végeztek, és igazolták, hogy az általuk vizsgált Aspergillus fajok, illetve a nemzetséghez tartozó teleomorf alakok monofiletikus csoportot alkotnak. Houbraken és munkatársai (2014) 25 gén bevonásával filogenetikai vizsgálatot végeztek biotechnológiai alkalmazásuk miatt fontos fajokkal, és szintén arra jutottak, hogy a nemzetségbe tartozó anamorf és teleomorf fajok monofiletikus csoportot alkotnak (bootstrap: 100\%). A vizsgálatba bevont teleomorf törzsek nagyfokú rokonságot mutattak az egyes alnemzetségekkel, az Eurotium nemzetség az Aspergillus; a Petromyces, Neopetromyces és Fennellia nemzetségek a Circumdati; a Neocarpenteles, Neosartorya és Dichotomomyces nemzetségek a Fumigati; a Chaetosartorya és Cristaspora nemzetségek a Cremei; az Emericella nemzetség pedig a Nidulantes alnemzetséggel mutatott rokonságot. Azon elveknek a megvalósulása, hogy egy gombafaj csak egy névvel rendelkezzen (,one fungus - one name” Nemzetközi Botanikai Kongresszus, Melbourne 2011) a nemzetség nevezéktanában változásokat követel. Ennek megoldására különböző lehetőségek vázolhatók fel (Samson és mtsai. 2014). Az egyik lehetőség a nemzetséget alkotó kládok eltérő nemzetségnevekkel történő ellátása, melynek eredményeként az egyes kládok tagjai a csoportba sorolt teleomorf alakok korábbi nemzetségneveit kapnák, mint például Neosartorya, Emericella, Petromyces stb. Az Aspergillus nevet csak az Aspergillus szekció tagjai őriznék meg, mivel ide tartozik a nemzetség típusfaja, az A. glaucus. Ez természetesen magával vonná az Eurotium név megszünését. Lehetséges másik típusfaj kijelölése is, de ebben az esetben is csak az a szekció őrizhetné meg az Aspergillus nevet, amelybe az újonnan kijelölt típusfaj tartozik. Az új típusfaj kiválasztása viszont vitákat eredményezne, mert több szekció tagjai között is találhatunk gazdaságilag nagy jelentőségü, a klinikumban fontos, vagy egyéb szempontok alapján előtérbe helyezhető fajokat. A harmadik - és valószínűleg a legésszerübb - megoldás az lenne, ha minden ide tartozó faj az Aspergillus nevet viselné, a korábbi elnevezés pedig jelzőként maradna meg (pl. A. glaucus eurotium-típusú ascoma-val).

A filogenetikai fajazonosításhoz a leggyakrabban a rRNS-eket kódoló szakasz ITS

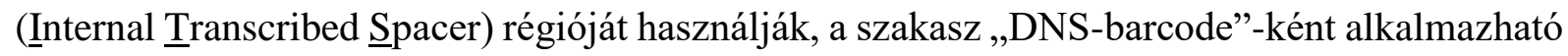
a gombák esetében (Schoch és mtsai. 2012). Ez a DNS szakasz azonban sajnos nem alkalmas minden Aspergillus faj elkülönítésére, ezekben az esetekben másodlagos marker is szükséges a faj pontos azonosításához (Schoch és mtsai. 2012). A másodlagos marker esetében fontos, hogy 
univerzális indítószekvenciák (primerek) legyenek tervezhetők rá, továbbá egyszerüen felszaporítható, és minden faj elkülönítésére alkalmas legyen. Természetesen az aktuális adatbázis teljessége is fontos szempont, olyan génszakaszt érdemes választani, amelynek bázissorrendje a legtöbb fajból már rendelkezésre áll. Ezen szempontok alapján az Aspergillus nemzetségben három lehetőség kínálkozik: a kalmodulint, a $\beta$-tubulint, valamint az RNSpolimeráz II második legnagyobb alegységét (RPB2) kódoló génszakaszok. Az RPB2 azonban nem tartozik a könnyen amplifikálható szakaszok közé. A kalmodulint kódoló gén egy szakasza könnyen felszaporítható, a bázissorrend alapján szinte minden faj elkülöníthető egymástól (kivéve pl. A. elegans és A. steynii, melyek ITS-szekvenciáik alapján azonban elkülöníthetők; Visagie és mtsai. 2014b), és az adatbázis majdnem teljes, tehát alkalmas arra, hogy másodlagos markerként használjuk (Samson és mtsai. 2014).

\section{Fekete Aspergillus-ok jellemzése, taxonómiai helyzetük}

Fekete Aspergillus-oknak az Aspergillus nemzetség Nigri szekciójába tartozó fajokat nevezzük (Gams és mtsai. 1985). A fekete Aspergillus-ok konídiumai általában sötét színúek, a sötétszürke és a fekete között minden átmeneti szín jellemző lehet. A csoport egyes képviselői nagy jelentőséggel rendelkeznek orvosi, élelmiszer-mikrobiológiai, valamint biotechnológiai szempontból egyaránt. A csoport legismertebb képviselöje az A. niger, melyet citromsav és glükonsav termeltetésére, továbbá számos enzim, pl. pektináz, amiláz előállítására is használnak (Varga és mtsai. 2000). Hasznos tulajdonságaik mellett azonban azt is meg kell említeni, hogy okozhatnak humán megbetegedéseket, általában immunszupresszált betegekben. Az ide tartozó fajok élemiszerekben is előfordulhatnak. Ennek jelentősége abban áll, hogy a fekete Aspergillus-ok különböző mikotoxinok (ochratoxinok, fumonizinek) termelésére képesek, melyek elfogyasztása kerülendő, hiszen ezek a mikotoxinok állatokra és emberekre egyaránt káros hatást fejtenek ki.

A fekete Aspergillus fajok elkülönítésére különböző módszerek léteznek, de pusztán morfológiai karakterek alapján a pontos meghatározásuk nehéz, néhány esetben pedig nem is lehetséges. Samson és munkatársai (2007) vizsgálatuk során áttekintették az egyes fajok, fajcsoportok elkülönítésére alkalmas bélyegeket. Eredményeik alapján azon fajok, melyek szkleróciumot hoznak létre (A. carbonarius, A. ellipticus, A. aculeatus, A. costaricaensis, A. piperis, A. sclerotioniger, A. aculeatinus és A. sclerotiicarbonarius), elkülöníthetők a növekedés mintázata alapján, más csoportok, mint az A. niger és rokonai azonban nem különböztethetők meg (1. ábra). 
A konídiumok mérete és mintázata alapján csak fajcsoportokat különíthetünk el. Néhány fajnak nagy, 7-9 $\mu \mathrm{m}$-es (A. carbonarius, A. ibericus, A. homomorphus, $A$. sclerotiicarbonarius és A. sclerotioniger), azonban a legtöbb fajnak ennél kisebb 3-4,5 $\mu$ m-es konídiumaik vannak (2. ábra). Néhány esetben a konídium mintázata is jellemző, pl. az A. ibericus és A. homomorphus konídiumai tüskések.

A kreatin-szacharóz agar (CREA) táptalajon történő tenyésztést használják különböző gombacsoportok esetében a fajok meghatározására (pl. Penicillium fajok, Samson és mtsai. 2004, Frisvad és Samson 2004). Növekedésük, savtermelésük alapján a fekete Aspergillus-ok körében is alkalmas a módszer fajcsoportok elkülönítésére. Az A. niger-nél és rokon fajainál mérsékelt telepnövekedés és erős savtermelés jellemző. A MEA-B (Pollastro és mtsai. 2006) táptalajon mindössze néhány faj (A. carbonarius, A. sclerotioniger, A. sclerotiicarbonarius) képes konídiumot létrehozni, ennek a módszernek használatával tehát kimutathatóvá válik az ochratoxintermelő A. carbonarius faj esetleges jelenléte.

Az Ehrlich-reakció segítségével vizsgálhatjuk egyes indolcsoportot tartalmazó másodlagos metabolitok jelenlétét az agaron fejlődő kolóniákban. Ez alapján a fekete Aspergillus fajokat csoportokra oszthatjuk. Az A. heteromorphus és az A. homomorphus pozitív reakciót ad, sárga elszíneződés tapasztalható, amely körül lila gyürü jelenik meg. Az $A$. costaricaensis telepek körül kék elszíneződés tapasztalható. Az A. brasiliensis, A. acidus és A. niger sárga reakciót adnak, míg az A. tubingensis-nél és rokonainál nem tapasztalható kék, lila vagy sárga elszíneződés a reagenst tartalmazó szürőpapíron. 


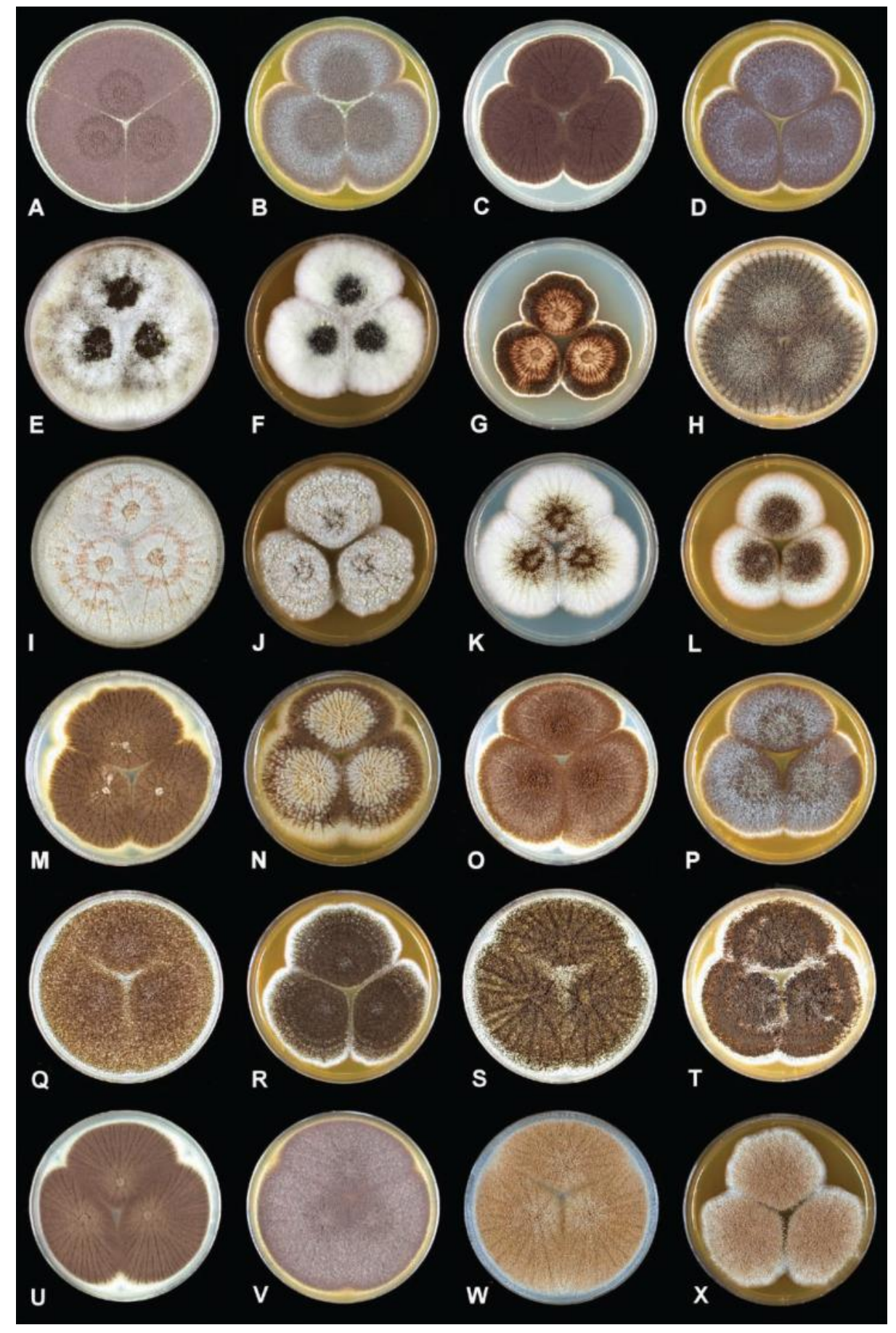

1. ábra. Néhány fekete Aspergillus faj növekedési mintázata CYA és MEA táptalajokon $25^{\circ} \mathrm{C}$-on történö, 7 napos növekedés után. (A-B) A. aculeatinus, (C-D) A. aculeatus, (E-F) A. brasiliensis, (G-H) A. carbonarius, (I-J) A. costaricaensis, (K-L) A. ellipticus, (M-N) A. foetidus, (O-P) A. japonicus, (Q-R) A. heteromorphus, (S-T) A. homomorphus, (U-V) A. ibericus, (W-X) A. lacticoffeatus (Samson és mtsai. 2007). 


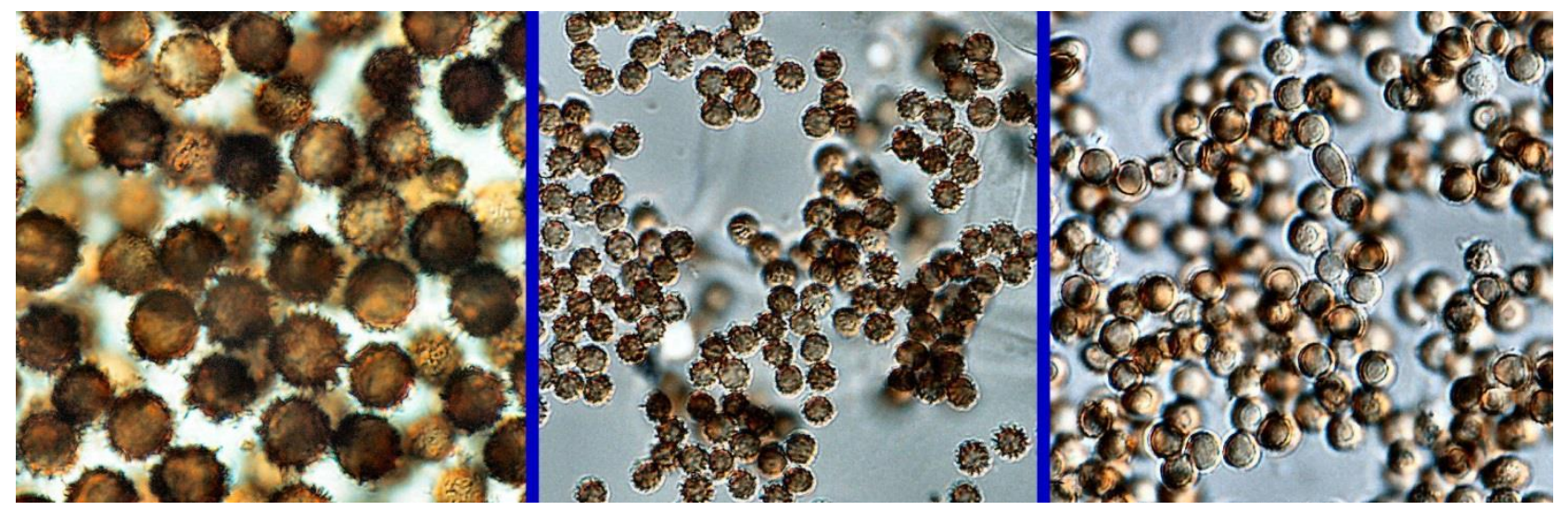

2. ábra. Fekete Aspergillus fajok konídiumainak fénymikroszkópos képe. A. carbonarius (7-9 $\mu \mathrm{m})$, A. costaricaensis (3,1-4,5 $\mu \mathrm{m})$, A. ellipticus (3,3-5,5 $\mu \mathrm{m})$ (Samson és mtsai. 2007).

A klasszikus módszerek mellett különböző molekuláris módszerek is rendelkezésre állnak a fekete Aspergillus fajok osztályozására. Ezek közül az egyik az RFLP (Restriction Fragment Length Polymorphism), amely mind sejtmagi, mind mitokondriális DNS használatával sikeresen alkalmazható a fajok elkülönítésére, illetve új fajok azonosítására. Kusters-van Someren és munkatársai (1991) kiterjedt sejtmagi DNS RFLP-vizsgálatot végeztek számos, gyűjteményből származó fekete Aspergillus törzzsel. A riboszómális DNS (rDNS) SmaI restrikciós endonukleázzal történő hasítása alapján az A. niger fajkomplexen belül két csoportot különítettek el, melyek morfológiai karakterek alapján nem voltak elkülöníthetők. A két csoport pektin-liáz gének ( $p e l A$, pelB) és a piruvát kináz gén ( $p k i)$ DNS-hibridizációs vizsgálata során is elválasztható volt egyméstól. A két csoportot ezért fajszintre emelték $(A$. niger és A. tubingensis). Az A. foetidus-t Al-Musallam (1980) emelte fajszintre morfológiai alapon, azonban sejtmagi DNS RFLP alapján nem különíthető el az A. niger-től, az A. helicothrix az A. ellipticus morfológiai variánsának bizonyult, az A. aculeatus és az A. japonicus SmaI-el emésztett rDNS mintázata pedig egyforma. Varga és munkatársai (1994) négy csoportot figyeltek meg az A. niger fajkomplexen belül, rDNS profiljuk alapján: az I-es és IIIas típusba az A. niger és A. brasiliensis törzsek, míg a II-es és IV-es csoportba az A. tubingensis törzsek tartoztak. Az A. japonicus és az A. aculeatus fajokat Parenicova és munkatársai (2001) azonosították RFLP analízis segítségével, munkájuk során hibridizációs próbaként $A$. niger piruvát-kináz (pkiA) és pektin-liáz (pelA), valamint Agaricus bisporus $28 \mathrm{~S}$ rRNS géneket használtak, melyekkel sikerült őket egymástól elkülöníteni. A mitokondriális DNS (mtDNS) is jelentős variabilitást mutat az egyes fajok között az A. niger fajkomplexen belül. Mind gyüjteményből származó törzseket, mind természetes populációkat vizsgálva, elkülöníthetőek 
voltak egymástól az A. niger és A. tubingensis fajok HaeIII és BglII enzimekkel hasított mtDNS-mintázataik alapján (Varga és mtsai. 1993). Néhány brazil izolátum különbözött ezektől, egy harmadik csoportot alkotva, ezeket később A. brasiliensis fajként írták le (Varga és mtsai. 2007).

Egy másik lehetőség a fekete Aspergillus fajok variabilitásának vizsgálatára a RAPDPCR (Random Amplified Polymorphic DNA - Polymerase Chain Reaction) analízis (Megnegneau és mtsai. 1993). A módszer lényege, hogy csak egy, 10 nukleotid hosszúságú primert alkalmaznak, melynek a szekvenciája ismert, de random. A felszaporított fragmentumokat agaróz gélen választják el. Megnegneau és munkatársai (1993) 6 random primer felhasználásával el tudták különíteni egymástól az A. carbonarius, A. japonicus, A. aculeatus, A. heteromorphus és A. ellipticus fajokat, valamint sikerült az A. niger fajkomplex törzseit ezzel a módszerrel is két csoportra osztani, melyek az A. niger és A. tubingensis fajoknak feleltek meg. Az A. aculeatus faj szintén megkülönböztethető az A. japonicus törzsektől 4 primer segítségével (Hamari és mtsai. 1997), és az A. brasiliensis is egyértelmủen elkülöníthető az A. niger fajkomplex többi képviselöjétől (Varga és mtsai. 2000). Az AFLP

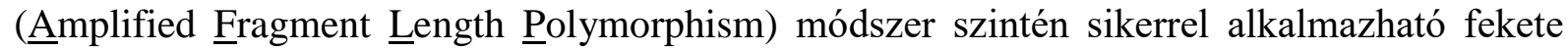
Aspergillus fajok elkülönítésére (Perrone és mtsai. 2006, Varga és mtsai. 2007).

Accensi és munkatársai (1999) PCR-RFLP technikával különböztettek meg A. niger és A. tubingensis izolátumokat. A módszer lényege, hogy az amplifikált DNS-fragmentumot restrikciós endonukleázzal emésztették, így kombinálni lehet a PCR és az RFLP-analízis előnyeit. Az izolátumokból felszaporított ITS-régiót RsaI restrikciós endonukleázzal emésztették, a kapott mintázat alapján az A. niger fajkompex tagjait $\mathrm{N}$ és T típusokba sorolták, ami az A niger és az A. tubingensis izolátumoknak felel meg. A különbség azzal magyarázható, hogy az A. niger-ben található ITS-régió tartalmazza az $R s a$ I enzim restrikciós hasító helyét (5'-GT/AC-3'), míg az A. tubingensis-é nem. In silico vizsgálatok alapján a T típusba tartoznak még az A. foetidus, A. vadensis, A. piperis és az A. costaricensis izolátumok is, a többi faj pedig $\mathrm{N}$ típusú mintázatot mutat (Samson és mtsai. 2007).

Napjainkban a DNS és aminósav szekvenciaalapú azonosítást széles körben alkalmazzák a fajmeghatározásban. Az Aspergillus nemzetség Nigri szekcióján belül minden faj megkülönböztethető egymástól kalmodulin-szekvenciáik alapján (3. ábra), illetve egy kivételével mindegyik elkülöníthető $\beta$-tubulin szekvenciáik alapján (az A. lacticoffeatus $\beta$ tubulin szekvenciái megegyeznek néhány A. niger izolátuméval; Samson és mtsai. 2004, Varga és mtsai. 2007). ITS-szekvenciáik alapján az A. niger fajkomplex tagjai négy csoportba 
sorolhatók: 1. A. niger és A. lacticoffeatus, 2. A. brasiliensis, 3. A. costaricensis, 4. A. tubingensis, A. foetidus, A. vadensis és A. piperis (Varga és mtsai. 2007). A többi fekete Aspergillus faj közül az A. carbonarius és az A. sclerotioniger ITS-szekvenciái megegyeznek, valamint a legtöbb egysoros konídiumtartójú (uniseriate) fajnak is azonos ITS-szekvenciáik vannak (A. japonicus, A. aculeatus, A. uvarum). Yokoyama és munkatársai (2001) a mitokondriális citokróm b gén szekvenciáit használták a fekete Aspergillus-ok közötti filogenetikai kapcsolatok felderítésére, melynek során az analízist nukletotid- és aminosavszekvenciákkal is elvégezték. Utóbbi alapján öt csoport különíthető el: $A$. japonicus/A. aculeatus, A. niger, A. tubingensis, A. carbonarius és A. ellipticus, a nukleotidszekvenciák alapján azonban az A. niger és az A. tubingensis nem különböztethetők meg egymástól. Az IGS (Intergenic Spacer) régiót is vizsgálták, hogy használható-e fajmeghatározásra, azonban ez nagy fajon belüli variabilitást mutatott, ezért nem alkalmas fajszintű elkülönítésre (Samson és mtsai. 2007).

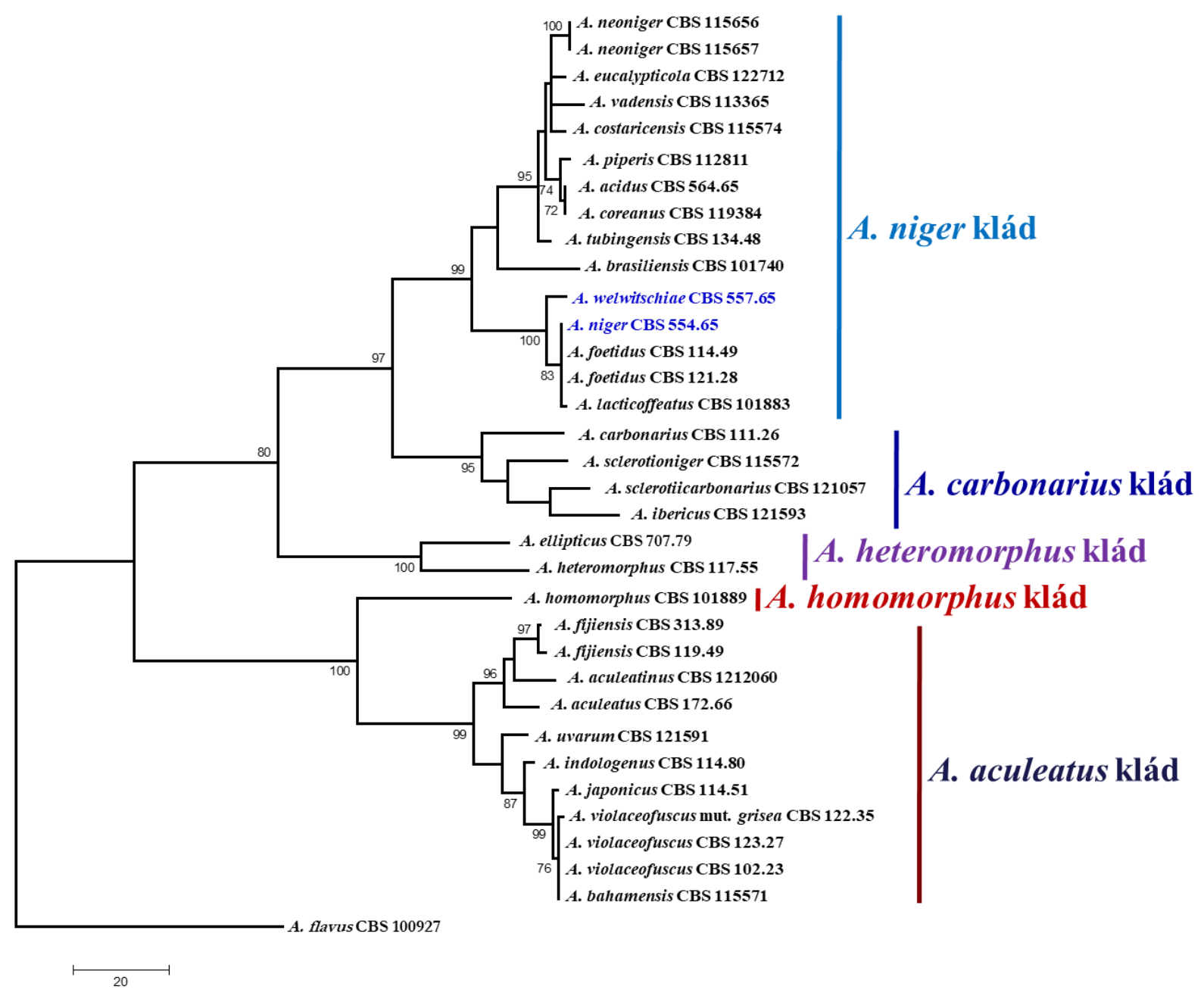

3. ábra. Az Aspergillus nemzetség Nigri szekciójának rokonsági viszonyai részleges kalmodulin génszekvenciáik alapján (Varga és mtsai. 2010) 


\section{Az A. niger és A. welwitscheae testvérfajok közötti különbségek}

Az Aspergillus nemzetség Nigri szekciójába tartozó két faj kalmodulin, $\beta$-tubulin és transzlációs elongációs faktor 1-alfa génjeik bázissorrendjei alapján egyértelmüen elkülöníthetőek egymástól, azonban morfológiai és fiziológiai tulajdonságaikban eddig nem sikerült különbségeket megállapítani (Perrone és mtsai. 2011).

Az Aspergillus nemzetség Nigri szekciójának egyes fajait különböző élelmiszerek fermentálására használják Kelet-Ázsiában. A japán Okinawa-szigeten népszerü, rizsből készült alkoholtartalmú, awamori-nak nevezett ital előállításához A. luchuensis és A. awamori törzseket alkalmaznak. Az A. awamori nevet Raper és Fennell (1965) egy olyan törzsnek adták, amely nem awamori fermentációból származott (CBS 557.65). Al-Musallam (1980) ezt a törzset később A. niger var. awamori-nak nevezte el. Ezt a típustörzset alapul véve Perrone és munkatársai (2011) az A. awamori-t, mint filogenetikai fajt írták le a Nigri szekción belül, mivel több gén szekvenciái alapján is egyértelmüen elkülöníthető az A. niger csoporttól. Vizsgálatukba bevontak az awamori fermentációjához használt törzseket is, de ezek egyike sem mutatott azonosságot az A. awamori törzsekkel. Később bizonyítást nyert, hogy az A. awamori törzsek az A. niger törzsekhez hasonlóan képesek lehetnek fumonizinek termelésére (Varga és mtsai. 2010, 2012). Hong és munkatársai (2013) közleményükben arra hívják fel a figyelmet, hogy a filogenetikai fajként elfogadott A. awamori-nak nevezett törzsek nem hozhatóak kapcsolatba a japán awamori előállításánál használt törzsekkel, azonban azonosságot mutatnak a namíbiai Welwitschia növényekröl származó A. welwitschiae (CBS 139.54) izolátummal. Eredményeik alapján az awamori fermentációjához használt törzsek pedig A. niger-nek, vagy A. luchuensis-nek bizonyultak. Fentiek következtében a Perrone és munkatársai (2011) által azonosított A. awamori filogenetikai faj az A. welwitschiae nevet kapta.

\section{Fekete Aspergillus-ok, mint humán patogének}

A fekete Aspergillus fajok a világ minden táján előfordulnak, konídiumaik mindenütt megtalálhatóak a levegőben, belélegzésük azonban általában nem okoz betegséget. Azok az egyének, akik valamilyen okból legyengült immunrendszerrel rendelkeznek (szervátültetettek, kemoterápiás, vagy szteroidos kezelésben részesülők, AIDS-es betegek, illetve más immunrendszert károsító betegségben szenvedők), hajlamosak a megbetegedésre, és esetükben a fertőzés halállal is végződhet (Levitz 1989). A modern immunszupresszáns terápiák elterjedésével az utóbbi években ezeknek a fertőzéseknek a száma és jelentősége egyaránt megnövekedett (Cohen és mtsai. 1993). 
Az Aspergillus fajok által okozott humán megbetegedések három csoportba sorolhatók: allergiás aszpergillózis, aszpergillóma és invazív aszpergillózis (Hogan és mtsai. 1996). A fertőzés leggyakrabban a légzőszervrendszerben jelentkezik, de szemfertőzést (keratitisz) és fülfertőzést (otitisz) is okozhatnak. Leggyakrabban az A. fumigatus okoz megbetegedést, de más Aspergillus fajok, mint például az A. flavus, A. terreus és az A. niger is jelentősek, mint opportunista humán patogének (Latgé 1999). Egymással közeli rokonságban álló Aspergillus fajok számos esetben morfológiai alapon nem különíthetőek el egymástól, pedig a klinikai izolátumoknál fontos a faj pontos isemerete, mert a hasonló megjelenésü izolátumok eltérő mértékben lehetnek érzékenyek gombaellenes szerekre. A megfelelő fajszintü azonosítás tehát segíthet a helyes gombaellenes terápia kiválasztásában (Balajee és mtsai. 2005). A fajazonosításra használható módszerek közül a molekuláris módszerek a legbiztosabbak. A $\beta$ tubulin vagy kalmodulin gének szekvenciái megfelelönek bizonyultak a fajszintü elkülönítéshez az Aspergillus nemzetségen belül (Samson és mtsai. 2007).

Balajee és munkatársai (2009) 218 Aspergillus izolátumot vizsgáltak, melyek szervátültetésen átesett betegekből származtak, akik feltételezhetően, vagy bizonyítottan invazív aszpergillózisban szenvedtek. A fajok meghatározását DNS-szekvenciák alapján végezték. Az ITS-szekvenciák alapján meghatározható volt, hogy az adott izolátum melyik fajkomplexhez tartozik, míg ezen belül a fajok elkülönítésére $\beta$-tubulin szekvenciákat használtak. Az izolátumokat korábban morfológiai bélyegek alapján határozták meg, mely egyezett az ITS-szekvenciák alapján végzett elkülönítéssel, tehát fajkomplex-szintig az Aspergillus izolátumok morfológiai alapon is meghatározhatók. A legtöbb izolátum az A. fumigatus fajkomplexbe tartozott, ezt követték az A. flavus, A. niger, A. terreus, A. ustus, A. versicolor, végül az A. nidulans fajkomplex képviselöi. A 19 fekete Aspergillus közül $\beta$-tubulin szekvenciáik alapján 6-ot $A$. tubingensis-nek, 13-at pedig A. niger-nek határoztak. Ez az első adat arról, hogy az A. tubingensis invazív aszpergillózist okozhat. Vizsgálták ezen felül az egyes Aspergillus izolátumok érzékenységét különbözö antifungális szerekre (amfotericin B, itrakonazol, vorikonazol, pozakonazol). A fekete Aspergillus izolátumok esetében a MIC (Minimum Inhibitory Concentration) érték alacsonynak bizonyult.

Alcazar-Fuoli és munkatársai (2009) 34, spanyol betegekből származó, klinikai fekete Aspergillus izolátumot vizsgáltak, melyeket korábban A. niger-nek határoztak morfológián alapuló módszerekkel. $\beta$-tubulin génszekvenciáik alapján az izolátumok 3 kládra különültek: a törzsek több mint fele (18) A. tubingensis-nek, 13 izolátum A. niger-nek, 3 pedig A. acidus-nak bizonyult. Tesztelték az izolátumok antifungális szerekkel szembeni érzékenységét is 
(amfotericin B, itrakonazol, vorikonazol, ravukonazol, pozakonazol, terbinafin, kaszpofungin, mikafungin), és megállapították az egyes szerekhez tartozó MIC és MEC (Minimum Effective Concentration) értékeket. Az itrakonazolhoz tartozó MIC-értékek alapján az izolátumok három jól elkülöníthető csoportra oszthatók. Ezek az alacsony és magas MIC-értékkel rendelkezők, és egy harmadik csoport, ami esetében ez a szer egy szokatlan, paradox hatást mutatott (Chamilos és mtsai. 2007). Ez abban nyilvánult meg, hogy a gomba a MIC-értéknél magasabb koncentráció mellett képes volt növekedni. Ez az első eset, hogy azolok paradox hatását tapasztalták Aspergillus fajokkal szemben. Mind a paradox hatást mutató, mind a magas itrakonazol MIC-értékkel rendelkező törzsek vorikonazol és ravukonazol MIC-értékei is magasak voltak. Az összes törzs érzékeny volt amphotericin B-re, terbinafinra és echinocandinra.

Howard és munkatársai (2011) 1994 és 2007 között Nagy-Britanniában izolált 43 klinikai fekete Aspergillus törzset vizsgáltak, és minden izolátum ITS-, kalmodulin. és $\beta$ tubulin-régióit megszekvenálták. A kalmodulin és $\beta$-tubulin gének alapján az izolátumok 5 kládot alkottak. A 43 izolátumból 25 A. welwitschiae-nek, 10 A. tubingensis-nek, 5 A. nigernek, 3 pedig A. acidus-nak bizonyult. Az ITS-szekvenciák nem voltak alkalmasak arra, hogy segítségükkel ezek a közeli rokon fajok elkülöníthetőek legyenek. Az izolátumok antifungális szerekkel szembeni érzékenységét is tesztelték, és azt tapasztalták, hogy 9/25 A. welwitschiae, 8/10 A. tubingensis, 2/5 A. niger és 3/3 A. acidus izolátum rezisztens volt itrakonazollal szemben (MIC > $4 \mathrm{mg} / \mathrm{l})$. Ez alátámasztja, hogy a fajcsoporton belül egyes fajok nagyobb rezisztenciát mutatnak az azolokkal szemben.

Kredics és munjatársai (2008) szemfertőzésekből származó indiai fekete Aspergillus izolátumok fajszintű eloszlását vizsgálták. A 7 izolátum közül 2-2 az A. brasiliensis, A. niger és A. tubingensis fajba tartozott, míg 1 törzs $A$. welwitschiae-nek bizonyult kalmodulin génszekvenciáik alapján. 


\section{Fülfertőzések}

A külső hallójárat gombás eredetü gyulladását (otitis externa mycotica) legtöbbször a Candida és Aspergillus nemzetségekbe tartozó gombák okozzák. Az otomikózis elterjedése globálisnak tekinthető, bár a meleg, nedves, poros környezetben gyakrabban jelenik meg (Joy és mtsai. 1980). Tünetei fülviszketés, fülfájás, halláscsökkenés és fülzúgás lehetnek. A gyulladás összefüggésben áll a felületi epiteliális hámlás következtében kialakuló törmelék jelenlétével, mely hifákat tartalmazhat. Súlyos esetben a fertőzés a külső hallójáratból átterjedhet a középfülre is, sőt a hallócsontokat is befedheti, bár ez utóbbi elsősorban immunszupresszált betegek esetében fordulhat elő (Kaur és mtsai. 2000). Az eddigi irodalmi adatok szerint az Aspergillus fajok közül az A. niger felelös a legtöbb megbetegedésért (Munguia és Daniel 2008, Bonifaz és mtsai. 2010, Fasunla és mtsai. 2007, Ozcan és mtsai. 2003), azonban a fülfertőzésekből származó fekete Aspergillus izolátumokat minden esetben morfológiai alapon azonosították, szekvenciaalapú fajazonosítás még nem történt.

\section{Fekete Aspergillus fajok mikotoxintermelő képessége}

\section{Ochratoxinok}

Az ochratoxin A (OTA) mikotoxint Aspergillus ochraceus törzsekben azonosították először (van der Merwe és mtsai. 1965). Ez a toxin erősen nefrotoxikus és hepatotoxikus, de immunszupresszáns, teratogén és karcinogén tulajdonságát is bizonyították (Smith és Moss 1985, Lea és mtsai. 1989). Az OTA összefüggésbe hozható a balkáni endemikus nefropátiás esetekkel (Krogh és mtsai. 1977). Rágcsálókon végzett kísérletek is igazolták az OTA karcinogén hatásait (Bendele és mtsai. 1985, Boorman és mtsai. 1992), melyek értelmében az OTA az egyik legpotensebb vesekarcinogén. Az állatkísérleti adatok alapján az OTA-t a Nemzetközi Rákkutatási Ügynökség (IARC, 1993), mint lehetséges humán karcinogént, a 2B csoportba sorolta.

Az ochratoxinok kémiai szerkezetük alapján dihidroizokumarin vázhoz kapcsolódó $\beta$ fenilalanin vegyületek. Biológiai hatásuk szempontjából elsősorban a klórszármazékok akut toxicitása nagy. Az OTA kevésbé toxikus, klórmentes származéka az ochratoxin B (4. ábra). 
<smiles>[R5]C[C@]1([R4])OC(=O)c2c(O)c(C([R])=O)cc([R2])c2[C@H]1[R3]</smiles>

$\begin{array}{lccccc} & \mathrm{R}_{1} & \mathrm{R}_{2} & \mathrm{R}_{3} & \mathrm{R}_{4} & \mathrm{R}_{5} \\ \text { Ochratoxin A } & \text { fenilalanil } & \mathrm{Cl} & \mathrm{H} & \mathrm{H} & \mathrm{H} \\ \text { Ochratoxin B } & \text { fenilalanil } & \mathrm{H} & \mathrm{H} & \mathrm{H} & \mathrm{H} \\ \text { Ochratoxin C } & \text { fenilalanil-etil-észter } & \mathrm{Cl} & \mathrm{H} & \mathrm{H} & \mathrm{H} \\ \text { Ochratoxin A-metil-észter } & \text { fenilalanil-metil-észter } & \mathrm{Cl} & \mathrm{H} & \mathrm{H} & \mathrm{H} \\ \text { Ochratoxin B-metil-észter } & \text { fenilalanil-metil-észter } & \mathrm{H} & \mathrm{H} & \mathrm{H} & \mathrm{H} \\ \text { Ochratoxin B-etil-észter } & \text { fenilalanil-etil-észter } & \mathrm{H} & \mathrm{H} & \mathrm{H} & \mathrm{H} \\ \text { Ochratoxin } \alpha & \mathrm{OH} & \mathrm{Cl} & \mathrm{H} & \mathrm{H} & \mathrm{H} \\ \text { Ochratoxin } \beta & \mathrm{OH} & \mathrm{H} & \mathrm{H} & \mathrm{H} & \mathrm{H} \\ \text { 4R-Hidroxiochratoxin A } & \text { fenilalanil } & \mathrm{Cl} & \mathrm{H} & \mathrm{OH} & \mathrm{H} \\ \text { 4S-Hidroxiochratoxin A } & \text { fenilalanil } & \mathrm{Cl} & \mathrm{OH} & \mathrm{H} & \mathrm{H} \\ \text { 10-Hidroxiochratoxin A } & \text { fenilalanil } & \mathrm{Cl} & \mathrm{H} & \mathrm{H} & \mathrm{OH}\end{array}$

4. ábra. Ochratoxinok szerkezete

Ochratoxinokat Aspergillus és Penicillium fajok is termelhetnek. Az OTA-termelő képességgel rendelkező fajok többsége az Aspergillus nemzetség Circumdati szekciójának tagja (Krogh 1978), de a nemzetség más szekcióiba tartozó fajok között is számos OTA-termelő fordul elö. A fekete Aspergillus fajok közül az A. carbonarius termel legnagyobb mennyiségben OTA-t (Téren és mtsai. 1996), de az A. niger és A. welwitschiae is termelheti ezt a mikotoxint (Varga és mtsai. 2009a).

\section{Fumonizinek}

A fumonizinek karcinogén mikotoxinok, melyeket Fusarium verticillioides-ben azonosítottak először (Gelderblom és mtsai. 1988; Bezudienhout és mtsai. 1988), majd más Fusarium fajokban is kimutatták (Marin és mtsai. 2004). Élelmiszer- és takarmánybiztonság szempontjából a legfontosabb toxinok közé tartoznak. A fumonizinek természetes előfordulása Fusarium verticillioides-szel fertőzött kukorica, illetve kukoricaalapú termékek esetében jelentős. Szardínián egyes kukoricatételekben $250 \mu \mathrm{g} / \mathrm{g}$ fumonizint is kimutattak, míg Koreában $150 \mathrm{mg} / \mathrm{kg}$ szintet is mértek. Hazánkban a legmagasabb eddig észlelt legnagyobb szennyezettség $75 \mathrm{mg} / \mathrm{kg}$ volt (Varga és mtsai. 2009b). 
Számos különböző fumonizin izomert azonosítottak (Bartók és mtsai. 2006), a leggyakrabban a $\mathrm{B}_{1}\left(\mathrm{FB}_{1}\right), \mathrm{B}_{2}\left(\mathrm{FB}_{2}\right)$ és $\mathrm{B}_{3}\left(\mathrm{FB}_{3}\right)$ fordulnak elő, ezek mindegyike rákkeltő hatású (5. ábra). Szerkezetük hasonló a szfingolipid intermedierekéhez, ezért akadályozzák azok metabolizmusát, azáltal, hogy gátolják a ceramid-szintáz enzimet (Wang és mtsai. 1991), így a szfinganin és a szfingozin mennyisége megemelkedik, a szfingolipidek képződése pedig gátlódik. A szabad szfingoid bázisok toxikusak, apoptózist idéznek elő a sejtben, ezáltal ezek felelősek a hepato- és nefrotoxikus hatásokért. A szfingolipidek esszenciális komponensei az eukarióta membránoknak, szerepük van továbbá a sejtnövekedésben és differenciálódásban is. A fumonizinek egyik hatása baromfiembriókban a rendellenes gericvelőcső-záródás, melyet a folsavtranszport gátlása révén idéznek elő. (Varga és mtsai. 2009b). A fumonizineket tartják felelősnek egyes dél-afrikai nyelőcsőrákos esetekért (Marasas és mtsai. 1988a; Yoshizava és mtsai. 1994), de okozhatják lovak agylágyulását (Marasas és mtsai. 1988b), valamint sertések tüdőödémáját is (Haschek és mtsai. 2001; Bouhet és mtsai. 2006). A FB patkányokban májrákot okoz, valamint hepato- és nefrotoxikus hatású (Stockmann-Juvala és Savolainen 2008). Ezen eredmények alapján a Nemzetközi Rákkutatási Ügynökség (IARC, 2002) a 2B karcinogén csoportba sorolta, ami azt jelenti, hogy ez a toxin lehetséges humán karcinogén.<smiles>[R]C(CCCCC([R2])CC(O)C(C)N)CC(C)CC(OC(=O)CC(CC(=O)O)C(=O)O)C(OC(=O)CC(CC(=O)O)C(=O)O)C(C)CCCC</smiles>

\section{$R_{1} \quad R_{2} \quad$ Összegképlet}

$\begin{array}{lccc}\text { Fumonizin } \mathrm{B}_{1} & \mathrm{OH} & \mathrm{OH} & \mathrm{C}_{34} \mathrm{H}_{59} \mathrm{NO}_{15} \\ \text { Fumonizin } \mathrm{B}_{2} & \mathrm{OH} & \mathrm{H} & \mathrm{C}_{43} \mathrm{H}_{59} \mathrm{NO}_{14} \\ \text { Fumonizin } \mathrm{B}_{3} & \mathrm{H} & \mathrm{OH} & \mathrm{C}_{34} \mathrm{H}_{59} \mathrm{NO}_{14} \\ \text { Fumonizin } \mathrm{B}_{4} & \mathrm{H} & \mathrm{H} & \mathrm{C}_{34} \mathrm{H}_{59} \mathrm{NO}_{13}\end{array}$

5. ábra. Fumonizinek szerkezete 
A fumonizin génklasztert $F$. verticillioides-ben Proctor és munkatársai (2003), valamint Brown és munkatársai (2005) jellemezték. A toxin termeléséért legalább 15 gén felelős, melyek egy $42 \mathrm{~kb}$ méretű génklaszterben helyezkednek el. Az A. niger törzsek teljes genomszekvenálása után kiderült, hogy ezek is tartalmaztak, a F. verticillioides-sel homológ fumonizin géneket (Baker 2006; Pel és mtsai. 2007). Mivel ez a két gombanemzetség nagyon távoli rokonságban áll egymással, vertikális géntranszferrel nehéz megmagyarázni a fumonizintermelő képességüket, de annak is kicsi a valószínüsége, hogy az egész génklaszter horizontális géntranszferrel jutott át a Fusarium-okból az Aspergillus-okba (Frisvad és mtsai. 2007).

A fumonizin-bioszintézis kulcsenzime egy poliketid-szintáz. A folyamat kezdeti lépéseként egy lineáris, $18 \mathrm{C}$-atomos lánc jön létre, melyhez egy oxoamin-oxidáz (FUM8) kapcsol további 2 C-atomot és egy amino-csoportot, melyek alaninból származnak. A karbonilcsoport redukciója és oxigenáció után két propán-1,2,3-trikarboxilsav kapcsolódik észterkötéssel a molekulához. A fumonizinek szerkezetileg rokon vegyületei az Alternaria fajok által termelt fitotoxikus AAL (ㅁlternaria alternata f. sp. lycopersici) toxinok, és az A. fumigatus szfingofungin nevü metabolitja (Varga és mtsai. 2009b). A Fusarium fajok növénykivonatot tartalmazó, alacsony só-, vagy cukortartalmú táptalajokon, magas vízaktivitás mellett, míg az A. niger izolátumok magas ozmotikumtartalmú (magas só- vagy cukortartalmú) táptalajokon termelnek nagyobb mennyiségben fumonizineket (Frisvad és mtsai. 2007).

A fekete Aspergillus-ok lehetséges fumonizin-termelése azért jelentős, mert sok élelmiszer- és takarmánynövényről tenyészthetők, így azok fumonizint tartalmazhatnak. Megtalálhatók szőlőn, kávén, hagymán, mangón, kukoricán és egyéb gabonákon, földimogyorón, szárított gyümölcsökön és még sok más terményen (Pitt és Hocking 1997). Irodalmi adatok alapján az A. niger fontos opportunista patogén különböző növényeken. Szőlő esetében fürt- és bogyórothadást okoz, és mazsoláról is izolálható (Varga és mtsai. 2004). Az ipari biotechnológiában az A. niger-t széles körben alkalmazzák, elsősorban citromsav, glükönsav és különböző extracelluláris enzimek termelésére, ezért felmerülhet ezeknek a termkeknek is a fumonizinekkel történő szennyeződése.

Az első adat A. niger fumonizin $B_{2}$-termeléséröl Frisvad és munkatársaitól (2007) származik. Később kávéról izolált $A$. niger törzsek FB2-termelését (Noonim és mtsai. 2009), majd szárított szőlőszemekről és mazsoláról izolált $A$. niger törzsek $\mathrm{FB}_{2}$ és $\mathrm{FB}_{4}$ termelését is kimutatták (Mogensen és mtsai. 2010). Mansson és munkatársai (2010) az A. niger $\mathrm{FB}_{2}$ és $\mathrm{FB}_{6}$ (izo-FB $)_{1}$ termelésére való képességét igazolták, míg Logrieco és munkatársai (2009) olasz mustmintákat vizsgáltak, melyek $\mathrm{FB}_{2}$-t tartalmaztak. 


\section{Célkitüzések}

Munkánk során a következő célokat tüztük ki:

- Az Aspergillus nemzetség átfogó filogenetikai elemzése az Aspergillus nemzetségen belüli rokonsági viszonyok pontos feltérképezése érdekében. Filogenetikai analízis 93 törzs bevonásával, ML és MrBayes módszerekkel.

- Két közeli rokon faj, az $A$. niger és $A$. welwitschiae genetikai variabilitásának vizsgálata. A két faj morfológiai alapon nem különíthető el egymástól, de kalmodulin szekvenciáik alapján egyértelmüen elkülönülnek. Kérdés, hogy ez a különbség kiterjede egyéb genomi régiókra is. A UP-PCR módszer alkalmas a genomszintű variabilitás vizsgálatára.

- Fülfertôzésekből származó fekete Aspergillus izolátumok azonosítása, érzékenységük vizsgálata különböző antifungális szerekkel szemben. Fülfertőzésekből eddig csak A. niger-t azonosítottak, de egyéb fekete Aspergillus fajok is okozhatnak opportunista mikózisokat. A morfológiai megjelenésükben egyforma fajok részleges kalmodulin szekveniáik alapján elkülöníthetőek. Az különböző fajok eltérő mértékben lehetnek érzékenyek antifungális szerekre. Leveshigításos mikrodilúciós módszerrel megállapítható egy törzs érzékenysége.

- Élelmiszerekről származó fekete Aspergillus izolátumok azonosítása, az izolátumok fumonizin-termelésének vizsgálata, valamint a vizsgált élelmiszerek fumonizin-tartalmának vizsgálata. Fekete Aspergillus-ok számos élelmiszerben előfordulhatnak, és potenciális fumonizin termelésük egészségügyi kockázatot jelent. Célunk fekete Aspergillus izolátumok gyüjtése, és ezek fajszintű azonosítása kalmodulin szekvenciáik alapján. A begyüjtött törzsek fumonizin termelésének, valamint a vizsgált élelmiszerek fumonizin tartalmának meghatározására HPLC-MS módszert alkalmazunk. 


\section{Anyagok és módszerek}

\section{Filogenetikai analízis}

\section{DNS-kivonás, felszaporitás, szekvenálás}

A filogenetikai vizsgálathoz a 1. táblázatban feltüntetett 93 törzset használtuk, melyeket a CBS (Utrecht, Hollandia) törzsgyüjteményéből szereztük be. A genomi DNS izolálása az Ultraclean Microbial DNA isolation kit (MoBio Laboratories, Carlsbad, USA) felhasználásával történt a gyártó utasításainak megfelelően. Az RPB1, RPB2, Tsr1, Cct8, MCM7 és Acl1 lókuszok szakaszai kerültek amplifikálásra, majd szekvenálásra a 2. táblázatban feltüntetett indítószekvenciák segítségével. A PCR-elegyek végtérfogata $25 \mu 1$ volt, összetételük az alábbi:

- $\quad 2,5 \mu 1$ 10-szeres PCR puffer

- $\quad 0,75 \mu 150 \mathrm{mM} \mathrm{MgCl}_{2}$

- $\quad 1,85 \mu 11 \mathrm{mM}$ dNTP mix

- 0,5-0,5 $\mu 1100 \mathrm{mM}$ primer

- $\quad 16,55 \mu 1$ steril bidesztillált víz

- $\quad 0,1 \mu 1$ Taq- polimeráz enzim (BioTaq, Bioline)

- $1 \mu 1$ templát DNS

A PCR során a következő programot alkalmaztuk:

1.) denaturáció: 30 másodperc, $94{ }^{\circ} \mathrm{C}$

2.) hibridizáció: 30 másodperc, $51-47^{\circ} \mathrm{C}$

3.) polimerizáció: 60 másodperc, $72{ }^{\circ} \mathrm{C}$

4.) utópolimerizáció: 10 perc, $72{ }^{\circ} \mathrm{C}$

Az 1-3. lépések összesen 40 ciklusban ismétlődtek. Az első öt ciklusban a hibridizáció hőmérséklete $51{ }^{\circ} \mathrm{C}$ volt, ezt 5 ciklusban $49{ }^{\circ} \mathrm{C}$-os hibridizációs hőmérséklet követte, majd az utolsó 30 ciklusban a primerkötődés $47^{\circ} \mathrm{C}$-on zajlott. Végül utópolimerizációs lépésként 72 ${ }^{\circ} \mathrm{C}$-ot alkalmaztunk 10 percen keresztül. A reakció végén a fölöslegben jelenlévő primer oligonukleotidokat és a dNTP mix maradékát QIAQuick PCR Purification Kit (Qiagen) segítségével távolítottuk el. A megtisztított PCR-termékeket $50 \mu 1$ steril bidesztillált vízben szuszpendáltuk. 
1. táblázat: A filogenetikai analízisbe bevont Aspergillus törzsek ( $\mathrm{NB}=$ nem besorolt)

\begin{tabular}{|c|c|c|c|}
\hline Nemzetség & Faj & Szekció & Típustörzs \\
\hline Aspergillus & aculeatus & Nigri & $172.66 \mathrm{~T}$ \\
\hline Aspergillus & aeneus & Aenei & CBS 128.54 \\
\hline Aspergillus & allahabadii & Terrei & CBS 164.63 \\
\hline Aspergillus & ambiguus & Terrei & CBS 117.58 \\
\hline Aspergillus & amylovorus & Usti & $600.67 \mathrm{~T}$ \\
\hline Aspergillus & arenarius & Nigri & $463.65 \mathrm{NT}$ \\
\hline Aspergillus & aureofulgens & Terrei & $653.74 \mathrm{~T}$ \\
\hline Aspergillus & avenaceus & Flavi & $109.46 \mathrm{NT}$ \\
\hline Aspergillus & biplanus & Sparsi & $468.65 \mathrm{NT}$ \\
\hline Aspergillus & bisporus & Bispori & $707.71 \mathrm{~T}$ \\
\hline Aspergillus & brasiliensis & Nigri & CBS 101740 \\
\hline Aspergillus & calidoustus & Usti & 121611 \\
\hline Aspergillus & campestris & Candidi & CBS 348.81 \\
\hline Aspergillus & candidus & Candidi & $566.65 \mathrm{NT}$ \\
\hline Aspergillus & cervinus & Cervini & $196.64 \mathrm{NT}$ \\
\hline Aspergillus & clavatoflavus & Flavi & $473.65 \mathrm{NT}$ \\
\hline Aspergillus & clavatus & Clavati & 128202 \\
\hline Aspergillus & conjunctus & Sparsi & $476.65 \mathrm{NT}$ \\
\hline Aspergillus & coremiiformis & Flavi & $553.77 \mathrm{~T}$ \\
\hline Aspergillus & deflectus & Usti & CBS 109.55 \\
\hline Aspergillus & duricaulis & Fumigati & CBS 481.65 \\
\hline Aspergillus & eburneocremeus & Aenei & CBS 130.54 \\
\hline Aspergillus & egyptiacus & Usti & $656.73 \mathrm{NT}$ \\
\hline Aspergillus & elongatus & Usti & CBS 387.75 \\
\hline Aspergillus & flavus & Flavi & NRRL 3357 \\
\hline Aspergillus & fumigatus & Fumigati & Af293 \\
\hline Aspergillus & funiculosus & Sparsi & $116.56 \mathrm{NT}$ \\
\hline Aspergillus & gorakhpurensis & Cremei & CBS 648.74 \\
\hline Aspergillus & gracilis & Restricti & CBS 115.36 \\
\hline Aspergillus & heteromorphus & Nigri & CBS 117.55 \\
\hline Aspergillus & heyangensis & Aenei & CBS 101751 \\
\hline Aspergillus & implicatus & Sparsi & CBS 484.95 \\
\hline Aspergillus & ivoriensis & Raperi & CBS 551.77 \\
\hline Aspergillus & janus & Terrei & $118.45 \mathrm{~T}$ \\
\hline Aspergillus & kanagawaensis & Cervini & $538.65 \mathrm{NT}$ \\
\hline Aspergillus & leporis & Flavi & $151.66 \mathrm{~T}$ \\
\hline Aspergillus & microcysticus & Terrei & CBS 120.58 \\
\hline Aspergillus & niger & Nigri & 513.88 \\
\hline Aspergillus & niveus var. indicus & Terrei & CBS 444.75 \\
\hline Aspergillus & ochraceoroseus & Ochraceorosei & 101887 \\
\hline Aspergillus & ochraceus & Circumdati & $108.08 \mathrm{NT}$ \\
\hline
\end{tabular}




\begin{tabular}{|c|c|c|c|}
\hline Nemzetség & Faj & Szekció & Típustörzs \\
\hline Aspergillus & panamensis & Sparsi & CBS 120.45 \\
\hline Aspergillus & penicillioides & Restricti & 130294 \\
\hline Aspergillus & proliferans & Aspergillus & CBS 121.45 \\
\hline Aspergillus & pulvinus & Cremei & $578.65 \mathrm{NT}$ \\
\hline Aspergillus & raperi & Raperi & CBS 123.56 \\
\hline Aspergillus & restrictus & Restricti & $117.33 \mathrm{NT}$ \\
\hline Aspergillus & robustus & Circumdati & $649.93 \mathrm{~T}$ \\
\hline Aspergillus & roseoglobosus & Circumdati & CBS 112800 \\
\hline Aspergillus & saccharolyticus & Nigri & CBS 127449 \\
\hline Aspergillus & sclerotiorum & Circumdati & CBS 549.65 \\
\hline Aspergillus & silvaticus & Silvati & CBS 128.55 \\
\hline Aspergillus & sparsus & Sparsi & $139.61 \mathrm{NT}$ \\
\hline Aspergillus & steynii & Circumdati & $112812 \mathrm{~T}$ \\
\hline Aspergillus & subsessilis & Terrei & CBS 502.65 \\
\hline Aspergillus & sydowii & Versicolores & 264.81 \\
\hline Aspergillus & terreus & Terrei & NIH 2624 \\
\hline Aspergillus & togoensis & Flavi & 272.89 \\
\hline Aspergillus & versicolor & Versicolores & 245.65 \\
\hline Aspergillus & viridinutans & Fumigati & CBS 127.56 \\
\hline Aspergillus & wentii & Cremei & $104.07 \mathrm{NT}$ \\
\hline Aspergillus & westerdijkiae & Circumdati & CBS 112803 \\
\hline Aspergillus & zonatus & Flavi & $506.65 \mathrm{NT}$ \\
\hline Aspergillus & tamarii & Flavi & SZMC 21469 \\
\hline Basipetospora & halophila & Polypaecili & $380.74 \mathrm{~T}$ \\
\hline Chaetosartorya & stromatoides & Cremei & CBS 265.73 \\
\hline Cristaspora & arxii & Cremei & $525.83 \mathrm{~T}$ \\
\hline Dichotomomyces & cejpii & Clavati & $157.66 \mathrm{NT}$ \\
\hline Emericella & aurantiobrunnea & Nidulantes & CBS 465.65 \\
\hline Emericella & heterothallica & Usti & CBS 489.65 \\
\hline Emericella & nidulans & Nidulantes & FGSC A4 \\
\hline Eurotium & amstelodami & Aspergillus & $518.65 \mathrm{NT}$ \\
\hline Eurotium & herbariorum & Aspergillus & $516.65 \mathrm{NT}$ \\
\hline Fennellia & flavipes & Terrei & $260.73 \mathrm{~T}$ \\
\hline Fennellia & neonivea & Terrei & CBS 115.27 \\
\hline Fennellia & nivea & Flavipedes & CBS 261.73 \\
\hline Hamigera & avellanea & NB & 295.48IsoT \\
\hline Hemicarpenteles & thaxteri & NB & CBS 105.25 \\
\hline Neocarpenteles & acanthosporum & Clavati & $558.71 \mathrm{~T}$ \\
\hline Neosartorya & fennelliae & Fumigati & CBS 598.74 \\
\hline Neosartorya & fischeri & Fumigati & NRRL 181T \\
\hline Neosartorya & pseudofischeri & Fumigati & CBS 208.92 \\
\hline Neosartorya & stramenia & Fumigati & CBS 498.65 \\
\hline Penicillium & inflatum & Cremei & CBS 682.70 \\
\hline
\end{tabular}




\begin{tabular}{cccc} 
Nemzetség & Faj & Szekció & Típustörzs \\
\hline Petromyces & alliaceus & Flavi & CBS 542.65 \\
Phialosimplex & caninus & Polypaecili & $128032 \mathrm{~T}$ \\
Phialosimplex & chlamydosporus & Polypaecili & $109945 \mathrm{~T}$ \\
Phialosimplex & sclerotialis & Polypaecili & $366.77 \mathrm{~T}$ \\
Polypaecilium & insolitum & Polypaecili & 384.61 \\
Sclerocleista & ornata & NB & $124.53 \mathrm{NT}$ \\
Sclerocleista & thaxteri & NB & 105.25 \\
Talaromyces & marneffei & NB & ATCC18284 \\
Warcupiella & spinulosa & NB & $512.65 \mathrm{NT}$
\end{tabular}

2. táblázat: A filogenetikai rekonstrukció során felhasznált indítószekvenciák

\begin{tabular}{|c|c|c|c|}
\hline Lókusz & Primer & Szekvencia (5'-3') & $\begin{array}{l}\text { PCR termék } \\
\text { mérete (bp) }\end{array}$ \\
\hline \multirow{3}{*}{ Acll } & F230Asp & AAGCCMGAYCARTTGATYAAG & \multirow{3}{*}{$\sim 770$} \\
\hline & & & \\
\hline & R943Asp & ARGCRCCRGTCTTRGCRTCC & \\
\hline \multirow{3}{*}{$M C M 7$} & F709FAsp & ACYCGIGTITCRGAYGTHAARCC & \multirow{3}{*}{$\sim 650$} \\
\hline & & & \\
\hline & R1348Asp & GAYTTRGCVACACCRGGRTCACCCAT & \\
\hline \multirow{3}{*}{$R P B 1$} & F1843 & ATTTYGAYGGTGAYGARATGAAC & \multirow{3}{*}{$\sim 1000$} \\
\hline & & & \\
\hline & R3096 & GRACRGTDCCRTCATAYTTRACC & \\
\hline \multirow{3}{*}{$R P B 2$} & 5F_Eur & GAYGAYCGKGAYCAYTTCGG & \multirow{3}{*}{$\sim 1220$} \\
\hline & & & \\
\hline & 7CR_Eur & CCCATRGCYTGYTTRCCCAT & \\
\hline \multirow{3}{*}{ Tsrl } & F1626 & GARTAYCCBCARTCNGAIATGT & \multirow{3}{*}{$\sim 820$} \\
\hline & & & \\
\hline & R2434 & ASAGYTGVARDGCCTTRAACCA & \\
\hline \multirow{3}{*}{ Cct8 } & F660 & GIGTKGTBAAGATCATGGGWGG & \multirow{3}{*}{$\sim 850$} \\
\hline & 2005 & 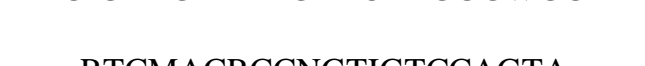 & \\
\hline & R1595 & RTCMACRCCNGTIGTCCAGTA & \\
\hline
\end{tabular}


A PCR-termékek szekvenálását a CBS Gombakutató Központban (Utrecht, Hollandia) végeztük. A szekvenciákat mindkét irányból leolvastuk. A felhasznált indítószekvencia-párok megegyeztek a PCR során használtakkal. A reakció összemérésénél a DYEnamic ET Terminator Cycle Sequencing Kit-et (Amersham Bioscience) használtuk. A szekvenáló reakció végtérfogata $10 \mu \mathrm{l}$ volt, melynek összetétele a következőképpen alakult:

- $\quad 0,85 \mu 1$ BigDye reagens

- $3 \mu 1$ puffer

- $\quad 4,75 \mu 1$ bidesztillált víz

- $\quad 0,4-0,4 \mu 110 \mathrm{mM}$-os primer

- $\quad 1 \mu 1$ templát DNS.

A reakció termékeit Sephadex G-50 oszlopokon (Amersham Bioscience) tisztítottuk a gyártó utasításainak megfelelően. A forward és reverz szekvenciákat a LeserGene programcsomag SeqMan programjának segítségével állítottuk össze kontiggá.

\section{Filogenetikai rekonstrukció}

A szekvenciák illesztését PRANK v.140603 módszerrel végeztük az alapértelmezett beállítások mellett (Löytynoja 2014). Az egyedi szekvenciákat a SequenceMatrix 1.8 program segítségével füztük össze (Vaidya és mtsai. 2011). Az adathalmazból a PhyML programmal egy Maximum Likelihood (ML) törzsfát generáltunk (Silvestro és Michalak 2012). Az analízis során $\mathrm{GTR}+\Gamma$ nukleotid-szubsztitúciós modellt alkalmaztunk. Az elágazások megbízhatóságának ellenőrzésére bootstrap analízist alkalmaztunk 1000 ismétlésben. A Bayesi analízis során a MrBayes 3.2.6 szoftvert alkalmaztuk (Ronquiest és mtsai. 2012) GTR $+\Gamma$ nukleotid-szubsztitúciós modell mellett. Az alkalmazott generációszám 107, a „burnin” 25\% volt. A két független futás alatt minden 1000. generációból történt a mintavétel. A robotok száma négy volt (1 hideg és 3 meleg lánc). Külcsoportnak egy Talaromyces marneffei törzset (ATCC 18224) választottunk.

\section{Az A. niger és az A. welwitscheae testvérfajok közötti különbségek vizsgálata}

\section{UP-PCR analizis}

Az analízis során a 3. táblázatban feltüntetett 8 primert használtuk fel. A mintázatokból összesen 88 fragmentumot vettünk figyelembe a bináris mátrix elkészítésénél. A filogenetikai analízist a PHYLIP programcsomag 3.67 (Felsenstein 2007) verziójának programjaival 
végeztük. A filogenetikai fát „,neighbor joining” módszerrel készítettük (Saitou és mtsai. 1987), a programcsomag Neighbor programjával.

3. táblázat: A UP-PCR analízis során használt indítószekvenciák (Bulat és mtsai. 1994, 2000, Lübeck és mtsai. 1998).

$\begin{array}{cc}\text { Primer neve } & \text { Szekvencia (5’'3’) } \\ \text { L45 } & \text { GTAAAACGACGGCCAGT } \\ \text { As15inv } & \text { CATTGCTGGCGAATCGG } \\ \text { L15/As19 } & \text { GAGGGTGGCGGCTAG } \\ \text { AA2M2 } & \text { CTGCGACCCAGAGCGG } \\ \text { L21 } & \text { GGATCCGAGGGTGGCGGTTCT } \\ \text { 3-2 } & \text { TAAGGGCGGTGCCAGT } \\ \text { AS4 } & \text { TGTGGGCGCTCGACAC } \\ \text { AS15 } & \\ \end{array}$

UP-PCR program:

1.) elődenaturáció: 1 perc, $94^{\circ} \mathrm{C}$

2.) denaturáció: 30 másodperc, $94{ }^{\circ} \mathrm{C}$

3.) hibridizáció: 45 másodperc, $55^{\circ} \mathrm{C}$

4.) polimerizáció: 1 perc, $72{ }^{\circ} \mathrm{C}$

5.) utópolimerizáció: 2 perc, $72{ }^{\circ} \mathrm{C}$

A 2-4. lépéseket 35 ciklusban hajtottuk végre.

Fülfertőzésekből származó fekete Aspergillus izolátumok vizsgálata

Vizsgált törzsek

A vizsgálathoz 14 Magyarországról és 7 Iránból származó törzset használtunk. A magyar törzseket a Szegedi Tudományegyetem Szent-Györgyi Albert Klinikai Központjából szereztük be, az iráni törzsek pedig a Jundishapur Orvostudományi Egyetemről érkeztek (Ahvaz, Irán). 


\section{Tiszta tenyészet létrehozása}

Az izolátumokat MEA (Biolab, Magyarország) táptalajon tenyésztettük 5 napig $25^{\circ} \mathrm{C}$ on, majd YPD (1\% élesztőkivonat, 1\% pepton, 1\% D-glükóz, 2\% agar) ferde agarra oltottuk át, további 5 napig inkubáltuk $25^{\circ} \mathrm{C}$-on, majd $4^{\circ} \mathrm{C}$-on tároltuk.

\section{A micélium felszaporítása, DNS izolálás}

A DNS-kivonáshoz a micélium felszaporítását mikrocentrifuga-csövekben végeztük. 1 ml YPD tápoldatba (1\% élesztőkivonat, $1 \%$ pepton, $1 \%$ D-glükóz) egy kacsnyi mintát oltottunk a tiszta tenyészetekből, majd 3 napig $25^{\circ} \mathrm{C}$-on rázattuk (120-150 rpm). Amennyiben megfelelő növekedést tapasztaltunk, a mikrocentrifuga-csöveket $10000 \mathrm{rpm}$-es fordulatszámon $(12350 \mathrm{~g})$ centrifugáltuk 3 percig, majd eltávolítottuk a tápoldatot a leülepedett micélium tetejéröl. A DNS-kivonáshoz az Epicentre Biotechnologies ${ }^{\circledR}$ MasterPure ${ }^{\mathrm{TM}}$ Yeast DNA Purification Kit-et használtuk a gyártó utasításainak megfelelően. A micéliumhoz steril homokot és lízis-puffert adtunk, és mikropisztillus segítségével mechanikai roncsolást alkalmaztunk. A DNS kivonatokat $-20^{\circ} \mathrm{C}$-on tároltuk.

\section{Az izolátumok molekuláris azonosítása kalmodulin szekvenciák alapján}

Cmd5 és Cmd6 indítószekvenciák (Hong és mtsai. 2006) a következők voltak:
Cmd5:
CCGAGTACAAGGAGGCCTTC
Cmd6:
CCGATAGAGGTCATAACGTGG

A kalmodulin PCR-reakcióelegy összetétele (20 $\mu$ l-es végtérfogatban):

Egyszeres töménységü Dream Taq puffer (1,5 mM $\mathrm{MgCl}_{2}$-ot tartalmaz) (Thermo Scientific)

0,02 mM dNTP-oldat (Thermo Scientific)

4-4 pmol Cmd5 és Cmd6 primer

0,2 $\mu \mathrm{l}$ (1 U) Dream-Taq DNS-polimeráz (Thermo Scientific)

$1 \mu 1(10-100 \mathrm{ng})$ templát DNS 
A kalmodulin PCR program:

A kívánt génszakasz sokszorosítására a Bio-Rad cég MJ Mini Gradient Thermal Cycler készülékét használtuk. A reakció lépései a következők voltak:

1.) elődenaturáció: 2 perc, $95^{\circ} \mathrm{C}$

2.) denaturáció: 30 másodperc, $95^{\circ} \mathrm{C}$

3.) hibridizáció: 40 másodperc, $56^{\circ} \mathrm{C}$

4.) polimerizáció: 45 másodperc, $72{ }^{\circ} \mathrm{C}$

5.) utópolimerizáció: 2 perc, $72^{\circ} \mathrm{C}$

A 2-4. lépéseket 35 ciklusban ismételtettük.

\section{Gélelektroforézis}

A PCR-termékeket 1\%-os agaróz gélen futtattuk 5-10 V/cm feszültség mellett horizontális gélelektroforézis készülék segítségével. A DNS-termékek méretének meghatározásához Gene Ruler 100 bp Plus DNA Ladder (Thermo Scientific) molekulasúlymarkert használtunk. A fragmentumok láthatóvá tételéhez GR Green DNS-festéket használtunk. Futtatás után a DNS-sávokat 254 nm-es UV-átvilágítással tettük láthatóvá. A gélfotók elkészítéséhez az UVP cég BioDoc-It ${ }^{\mathrm{TM}}$ géldokumentációs berendezését használtuk. A PCR-termékek szekvenálása a filogenetikai rekonstrukciónál leírtakhoz hasonlóan történt.

\section{A fajok meghatározása, törzsfa készitése}

A szekvenciákat a BioEdit programmal jelenítettük meg, majd ezeket egyenként a PubMed (http://www.ncbi.nlm.nih.gov) internetes adatbázisával vetettük össze „,nucleotide BLAST” segítségével (Altschul és mtsai. 1990). A szekvenciákat a MEGA szoftvercsomag 4. verziójának segítségével illesztettük (Tamura és mtsai. 2007). A hiányzó nukleotidokat a program ötödik karakterállapotként kezelte. A parszimónia szempontjából nem informatív karaktereket kizártuk. A program minden karaktert azonos súllyal vett figyelembe. A topológia megbízhatóságának ellenőrzésére bootstrap analízist alkalmaztunk 1000 ismétlésben (Hillis és Bull 1993). Külcsoportnak egy A. flavus törzset vontunk be a vizsgálatba.

\section{Fülfertözésekböl származó fekete Aspergillus izolátumok antifungális szerekkel szembeni érzékenységének vizsgálata}

Az kiválasztott antifungális szerek in vitro antifungális aktivitását leveshígításos mikrodilúciós módszerrel vizsgáltuk a Klinikai és Laboratóriumi Standardok Intézetének 
(Clinical and Laboratory Standards Institute - CLSI) ajánlása alapján (NCCLS 2002). A minimális gátló koncentráció (minimum inhibitory concentration - MIC) értékeket 96 lyukat tartalmazó mikrotiter-lemezeken határoztuk meg úgy, hogy az optikai denzitást (OD) mértük $620 \mathrm{~nm}$-en Jupiter HD mikrotiterlap-olvasó fotométer segítségével (ASYS Hitech GmbH, Eugendorf, Ausztria). A vizsgálathoz RPMI 1640 médiumot (Sigma-Aldrich) használtunk, mely tartalmazott L-glutamint, de nem tartalmazott Na-bikarbonátot. A tápleves pH-ját 7,0-re állítottuk be 0,165 M MOPS-oldat hozzáadásával.

Az izolátumokat YPD agarlemezen tenyésztettük 5 napig $25{ }^{\circ} \mathrm{C}$-on, majd konídiumszuszpenziót készítettünk steril fiziológiás sóoldatban. A konídiumok számát Bürker-kamra segítségével határoztuk meg, és $5 \times 10^{4}$ konídium/ml értékre állítottuk be. Ehhez a hígítást RPMI 1640 táplevesben végeztük. A vizsgálatba a következő antifungális szereket vontuk be: flukonazol, itrakonazol, ketokonazol, terbinafin, amfotericin B (Sigma-Aldrich). Az antifungális szereket DMSO-ban oldottuk fel. Az itrakonazol, terbinafin és amfotericin B esetében 0,031-16 $\mu \mathrm{g} / \mathrm{ml}$, a ketokonazolnál 0,062-32 $\mu \mathrm{g} / \mathrm{ml}$, míg flukonazolnál 0,125-64 $\mu \mathrm{g} / \mathrm{ml}$ koncentráció-tartományt állítottunk be felező hígítással. A lemezeket $35{ }^{\circ} \mathrm{C}$-on inkubáltuk 48 órán keresztül, majd meghatároztuk azt a koncentrációt, amely 100\%-os növekedési gátlást eredményezett $\left(\mathrm{MIC}_{100}\right)$.

\section{Élelmiszereken előforduló fekete Aspergillus izolátumok}

A vizsgált növényi részeket Diklorán-bengálrózsa-kloramfenikol (DRBC, $0,5 \%$ pepton, $1 \%$ glükóz, 0, $1 \% \mathrm{KH}_{2} \mathrm{PO}_{4}, 0,0002 \%$ Dichloran, 0,05\% $\mathrm{MgSO}_{4}, 0,01 \%$ kloramfenikol, 0,0025\% bengálrózsa, $2 \%$ agar) agarlemez felületére helyeztük, majd a lemezeket 3 napig $25{ }^{\circ} \mathrm{C}$-on, sötétben inkubáltuk. A tenyészetekből YPD agarlemezeken tiszta tenyészeteket készítettünk. A törzseket YPD ferde agaron, $4{ }^{\circ} \mathrm{C}$-on tároltuk. A fajszintü azonosításhoz és a törzsfa készítéséhez a fülfertőzésekből származó törzsek esetén alkalmazott módszereket használtuk.

\section{Fumonizin-extrakció}

A vizsgált élelmiszerek fumonizin-tartalmának vizsgálata során a növényi részek 1 gjához $8 \mathrm{ml}$ metanol:víz (1:3, v/v) elegyet mértünk. UltraTurrax T25 (IKA, Staufen, Németország) nagysebességű homogenizátort alkalmazva rázattuk a mintákat (20000 rpm, 4 perc) majd 10 percig $10000 \mathrm{rpm}$ fordulaton centrifugáltuk. A felülúszó fumonizintartalmát közvetlenül mértük RP-HPLC/ESI-IT-MS ${ }^{2}$ (Reversed-Phase High-Performance Liquid 


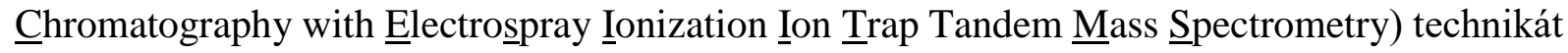
alkalmazva.

Az izolátumok fumonizintermelő képességének vizsgálata során a törzseket CYA20S táptalajon (20\% szacharóz, $0,5 \%$ élesztőkivonat, $0,1 \% \mathrm{~K}_{2} \mathrm{HPO}_{4}, 0,03 \% \mathrm{NaNO}_{3}, 0,005 \% \mathrm{KCl}$, $0,005 \% \mathrm{MgSO}_{4}, 0,0001 \% \mathrm{FeSO}_{4}, 0,0001 \% \mathrm{ZnSO}_{4}^{4}, 0,00005 \% \mathrm{CuSO}_{4}, 2 \%$ agar) tenyésztettük $25^{\circ} \mathrm{C}$-on, 7 napig. Az agarlemezekből dugófúróval $5 \mathrm{db} 6 \mathrm{~mm}$ átmérőjü korongot vágtunk ki csészénként. Az extrakciót $6 \mathrm{ml}$ metanol:víz (3:1; v/v) elegyével végeztük. A fent említett nagysebességü homogenizátort alkalmazva rázattuk a mintákat (20000 rpm, 4 perc), majd 10 percig 10000 rpm fordulaton centrifugáltuk. A felülúszóból 2 ml-t beszárítottunk, majd újra feloldottuk $500 \mu 1$ metanol:víz (3:1, v/v) elegyében. Ennek fumonizintartalmát közvetlenül vizsgáltuk RP-HPLC/ESI-IT-MS ${ }^{2}$ technikával.

Az analízis reverz fázisú HPLC/ESI-IT_MS módszerrel történt (Bartók és mtsai. 2006, 2010), egy Agilent 1090 Series II HPLC (Waldbronn, Germany) készülékkel. A HPLC elválasztást YMC-Pack J'sphere ODS H80 (YMC Europe GmbH, Dinslaken, Németország) (250 mm x 2,1 mm, $4 \mu \mathrm{m}$ ) HPLC oszlopokon végeztük. Az oldószergrádiens alkotói egyrészt desztillált víz és $0,1 \%$ hangyasav, másrészt acetonitril és $0,1 \%$ hangyasav voltak. Egy-egy $\mu 1$ mintát fecskendeztünk az oszlopokra. Az elválasztott vegyületeket Varian (Palo Alto, CA, USA) 500 IT-MS készülékkel detektáltuk, melyhez egy ESI forrás volt csatlakoztatva. A különböző fumonizin izomerek mennyiségét kalibrációs egyenes alapján számoltuk ki. 


\section{Eredmények és értékelésük}

\section{Az Aspergillus nemzetség filogenetikai analízise}

A teljes Aspergillus nemzetséget reprezentatívan mintázó filogenetikai vizsgálatot végeztünk 93 faj bevonásával. Az elemzés során 6 génszakaszt szaporítottunk fel, majd bázissorrendjüket meghatároztuk. Az RPB1, RPB2, Tsr1, illetve a $C c t 8$ (dajkafehérje) lókuszok már alkalmasnak bizonyultak az alnemzetség-szintü rokonsági kapcsolatok megállapítására a Penicillium nemzetségen belül (Houbraken és Samson 2011). Ezeken kívül bevontuk az Acl1 és MCM7 lókuszokat is az analízisbe. A szekvenciaadatok a GénBankba a következő azonosítókkal kerültek feltöltésre: KY006730-KY006827. A kapott szekvenciák adatait első megközelítésben önállóan, lókuszonként vizsgáltuk, majd - mivel az egyes lókuszok alapján számolt törzsfák között lényeges topológiai eltérés nem mutatkozott - egy kombinált adatsort hoztunk létre. A filogenetikai analízist ML és MrBayes módszerekkel végeztük el. A filogenetikai rekonstrukció eredményeit a 6. és 7. ábrák szemléltetik. 


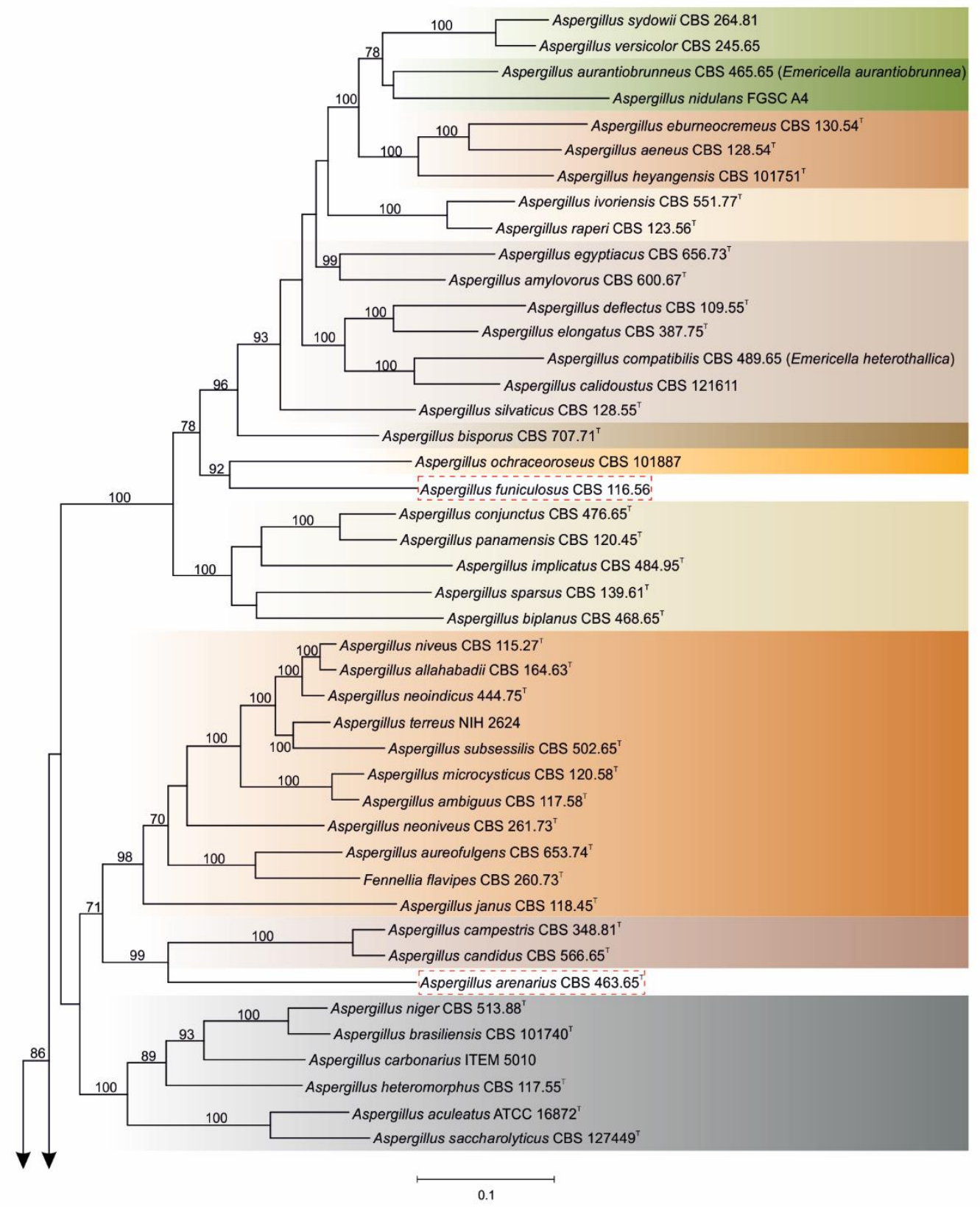

Versicolores szekció

Nidulantes szekció

Aenei szekció

Raperi szekció

Usti szekció

Bispori szekció

Ochraceorosei szekció

Sparsi szekció

Terrei szekció

Candidi szekció

Nigri szekció

6. ábra. Az Aspergillus nemzetséget reprezentáló 6 génen (RPB1, RPB2, Tsr1, Cct8, Acl1, MCM7) alapuló Makimum Likelihood (ML) módszerrel készített filogenetikai fa. Az ágakon a bootstrap értékek láthatók. Csak a 70\% feletti értékeket tüntettük fel. 


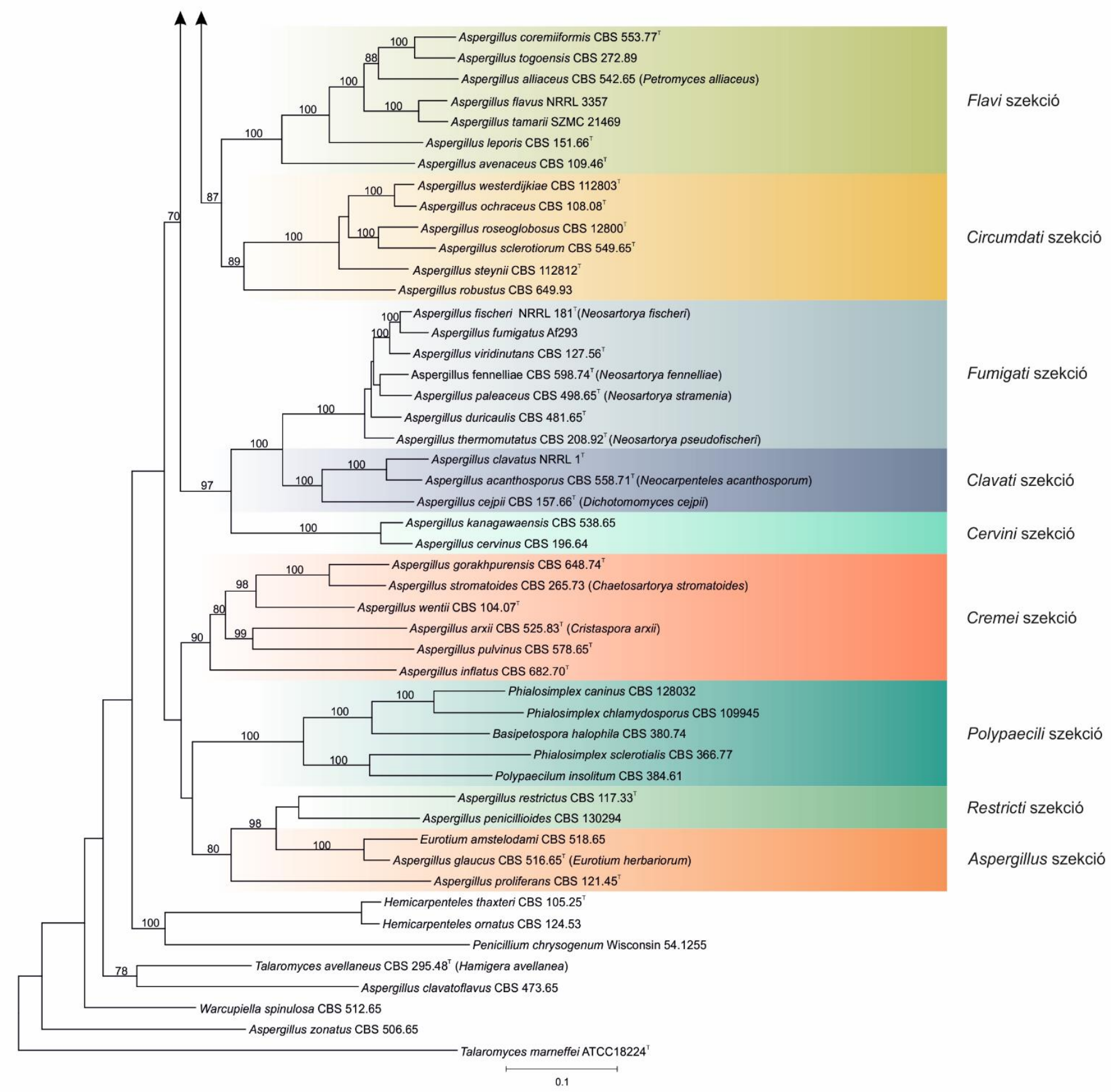

6. ábra (folytatás). Az Aspergillus nemzetséget reprezentáló 6 génen (RPB1, RPB2, Tsr1, Cct8, Acl1, MCM7) alapuló Makimum Likelihood (ML) módszerrel készített filogenetikai fa. Az ágakon a bootstrap értékek láthatók. Csak a 70\% feletti értékeket tüntettük fel. 


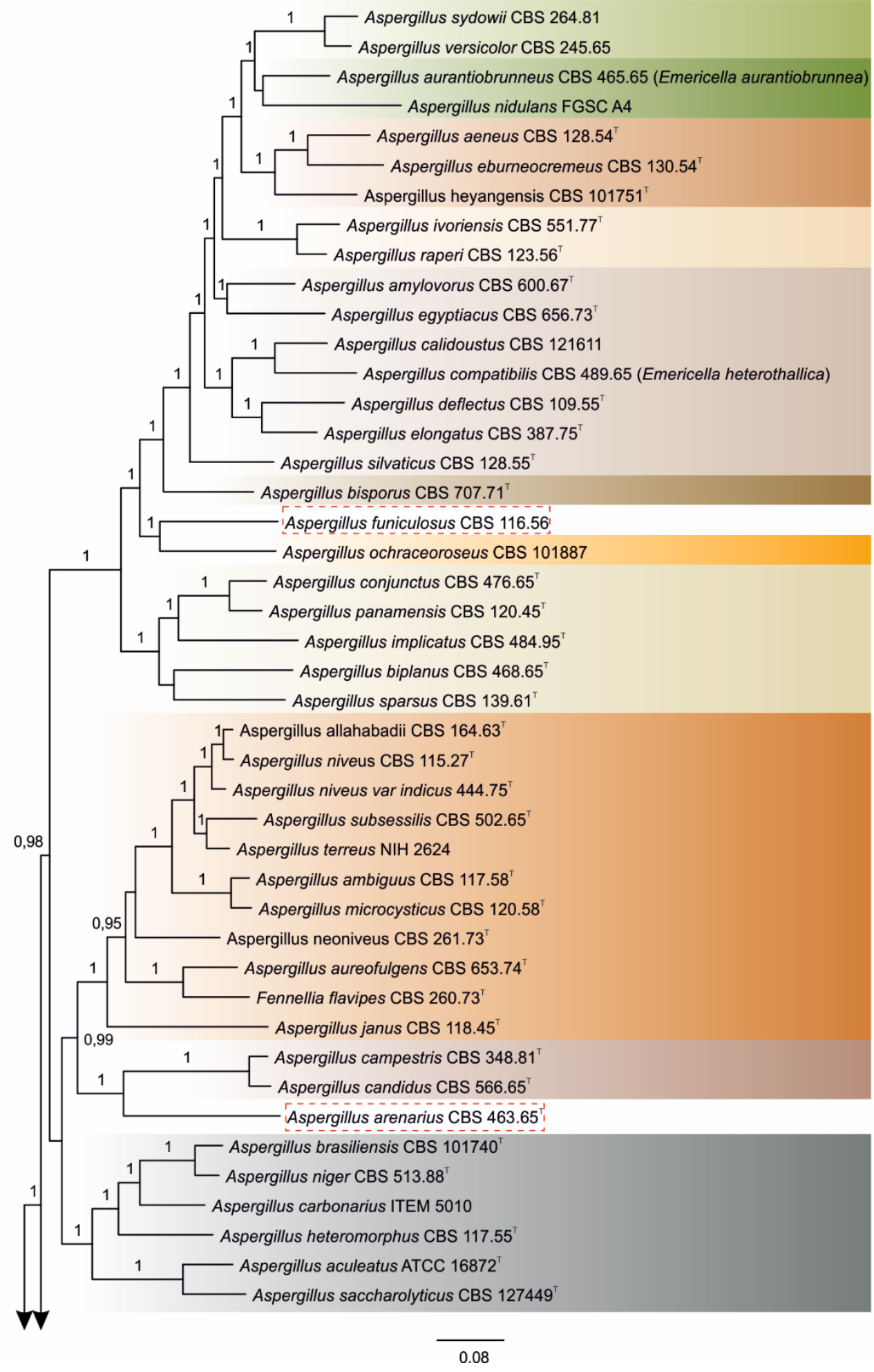

Versicolores szekció

Nidulantes szekció

Aenei szekció

Raperi szekció

Usti szekció

Bispori szekció

Ochraceorosei szekció

Sparsi szekció

Terrei szekció

Candidi szekció

Nigri szekció

7. ábra. Az Aspergillus nemzetséget reprezentáló 6 génen (RPB1, RPB2, Tsr1, Cct8, Acl1, $M C M 7)$ alapuló MrBayes módszerrel készített filogenetikai fa. Az ágakon a poszterior valószínüségek értékei láthatók. Csak a 0,95 feletti értékeket tüntettük fel. 


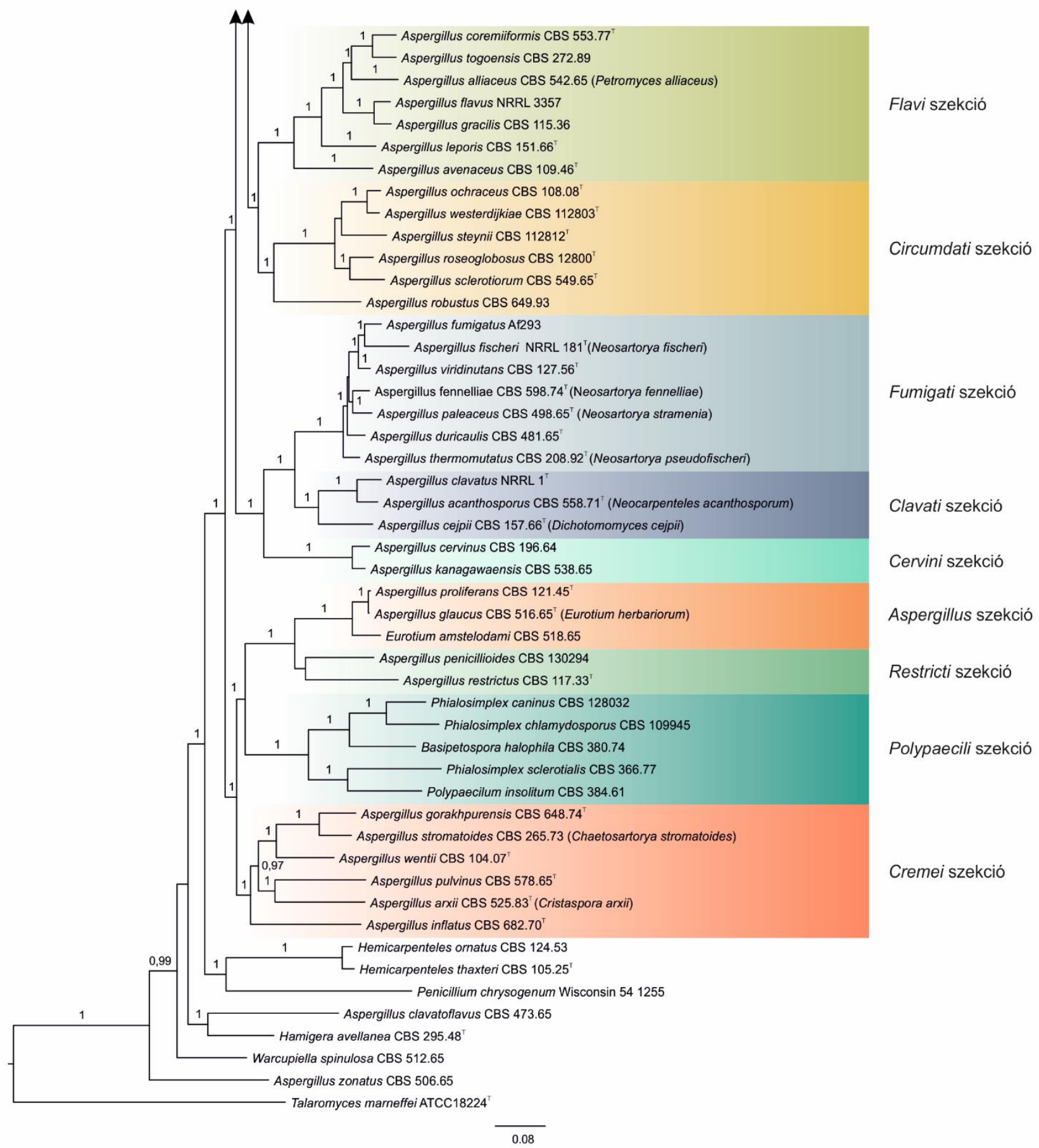

7. ábra (folytatás). Az Aspergillus nemzetséget reprezentáló 6 génen (RPB1, RPB2, Tsr1, Cct8, Acl1, MCM7) alapuló MrBayes módszerrel készített filogenetikai fa. Az ágakon a poszterior valószínüségek értékei láthatók. Csak a 0,95 feletti értékeket tüntettük fel. 
Eredményeink alapján az Aspergillus nemzetség 6 alnemzetségre és 23 szekcióra bontható (4. táblázat). Az Aspergillus (bootstrap érték: 80 / poszterior valószínüség: 1), Polypaecili (100/1), Cremei (90/1), Fumigati (97/1) és Nidulantes (100/1) alnemzetségek magas támogatottsági értékekkel rendelkeznek, a Circumdati (47/1) alnemzetség támogatottsága kisebb a ML analízis alapján. A filogenetikai analízis egyértelmüen azt mutatja, hogy az A. clavatoflavus és az A. zonatus fajok kívül esnek az Aspergillus nemzetségen. A nemzetségen belül a ML analízis alapján az Usti szekció kivételével minden szekció monofiletikusnak bizonyult közepes, vagy magas támogatottsági értékek mellett. Mind a MLmind a MrBayes analízis alapján az Usti szekció két csoportra különült, ahol az A. amylovorus és az A. egyptiacus fajok egy jól elhatárolódó kládot alkotnak magas támogatottsági értékek mellett (92/1). Houbraken és Samson (2011) munkájuk során elsősorban a Penicillium nemzetség átfogó filogenetikai vizsgálatára helyezték a hangsúlyt, de kitértek az egész Trichocomaceae család rokonsági viszonyaira is, így vizsgálatukba számos Aspergillus törzset is bevontak. Eredményeik alapján utaltak arra, hogy a vizsgált Polypaecilum és Phialosimplex nemzetségbe tartozó gombák az Aspergillus nemzetség Cremei és Aspergillus szekciójába tartozó fajokkal mutatnak rokonságot. Ezt az általunk végzett vizsgálat is megerősítette. Ennek következtében ezeket a fajokat ezentúl az Aspergillus nemzetség tagjainak tekintjük, ami a nevezéktanban is ennek megfelelő változást von maga után. Így a korábban Phialosimplex caninus, Phialosimplex clamydosporus, Phialosimplex sclerotiales, Polypaecilum insolitum, Polypaecilum pisci neveket viselő fajok az Aspergillus nemzetségnevet kapták (Kocsubé és mtsai. 2016). 
4. táblázat: Az alnemzetségek és szekciók alakulása az Aspergillus nemzetségen belül (A Petersoni szekciót nem vontuk be a dolgozatban részletezett munkába, de a Kocsubé és munkatársai (2016) által publikált vizsgálat megerösíti a helyzetüket.)

\begin{tabular}{cc}
\hline Szekció & Alnemzetség \\
\hline Usti & \\
Cavernicola & \\
Ochraceorosei & \\
Bispori & Nidulantes \\
Sparsi & \\
Nidulantes & \\
Aenei & \\
Raperi & \\
\hline Terrei & \\
Candidi & \\
Nigri & Circumdati \\
Flavi & \\
Circumdati & Polypaecili \\
Flavipedes & \\
Jani & \\
Petersoni & \\
\hline Fumigati & \\
Clavati & \\
Cervini & \\
\hline Cremei & \\
\hline Aspergillus & \\
\hline Polypaecilicti & \\
\hline & \\
\hline & \\
\hline & \\
\hline
\end{tabular}

Eredményeink alapján a korábban Penicillium inflatum-ként ismert faj az Aspergillus nemzetség Cremei szekciójában lévő fajokkal mutatott rokonságot. Peterson (1995, 2000) tanulmányozta korábban ezt a szekciót, és molekuláris tulajdonságok alapján ide sorolta az addig más szekciókba tartozó A. wentii (Wentii szekcióból), A. dimorphicus (Circumdati szekcióból), A. gorakhpurensis és A. pulvinus (Versicolores szekcióból) fajokat. A P. inflatum fajt Stolk és Malla (1971) írták le. Megfigyelték, hogy a konídiofórok megduzzadt csúcsi része 
és az erősen elágazó metula inkább az Aspergillus nemzetség tagjaira jellemző, de a talpsejtek hiánya, a konídiofórok vékony fala, és a metula nem egyidejűleg történő fejlődése miatt úgy döntöttek, hogy a fajt a Penicillium nemzetséghez sorolják. A P. inflatum termel sterigmatocisztint (Rank és mtsai. 2011), mely vegyületet kizárólag Aspergillus fajok termelnek (Samson és mtsai. 2014), ami szintén megerősíti, hogy ez a faj inkább az Aspergillus nemzetségbe sorolható, ezért az Aspergillus inflatus nevet kapta (Kocsubé és mtsai. 2016).

Egy Peterson (2008) munkája nyomán készült törzsfa 3 gén ( $R P B 2,5,8 \mathrm{~S}$ és részleges 28S rDNS) szekvenciáit alapul véve ábrázolja az Aspergillus nemzetség legfontosabb szekcióit, melyek három nagy csoportra különülnek (8. ábra). Ezen a törzsfán a Terrei, Flavipedes és Candidi szekciók egy nagy kládot alkotnak. A Nigri szekció a Flavi szekció testvérkládjaként jelenik meg, magas támogatottsági érték mellett. A Circumdati és Cremei szekciók önálló kládként jelennek meg. A Fumigati, Clavati és Cervini szekciók egy ágon helyezkednek el, egymástól azonban jól elkülönülnek. A törzsfán elhelyezkedő fajok következő nagy csoportját a Nidulantes, Usti és Sparsi szekciók alkotják. A Versicolores szekció a Nidulantes szekción belül helyezkedik el. Az Aspergillus és Restricti szekciók testvérkládokat alkotnak. 


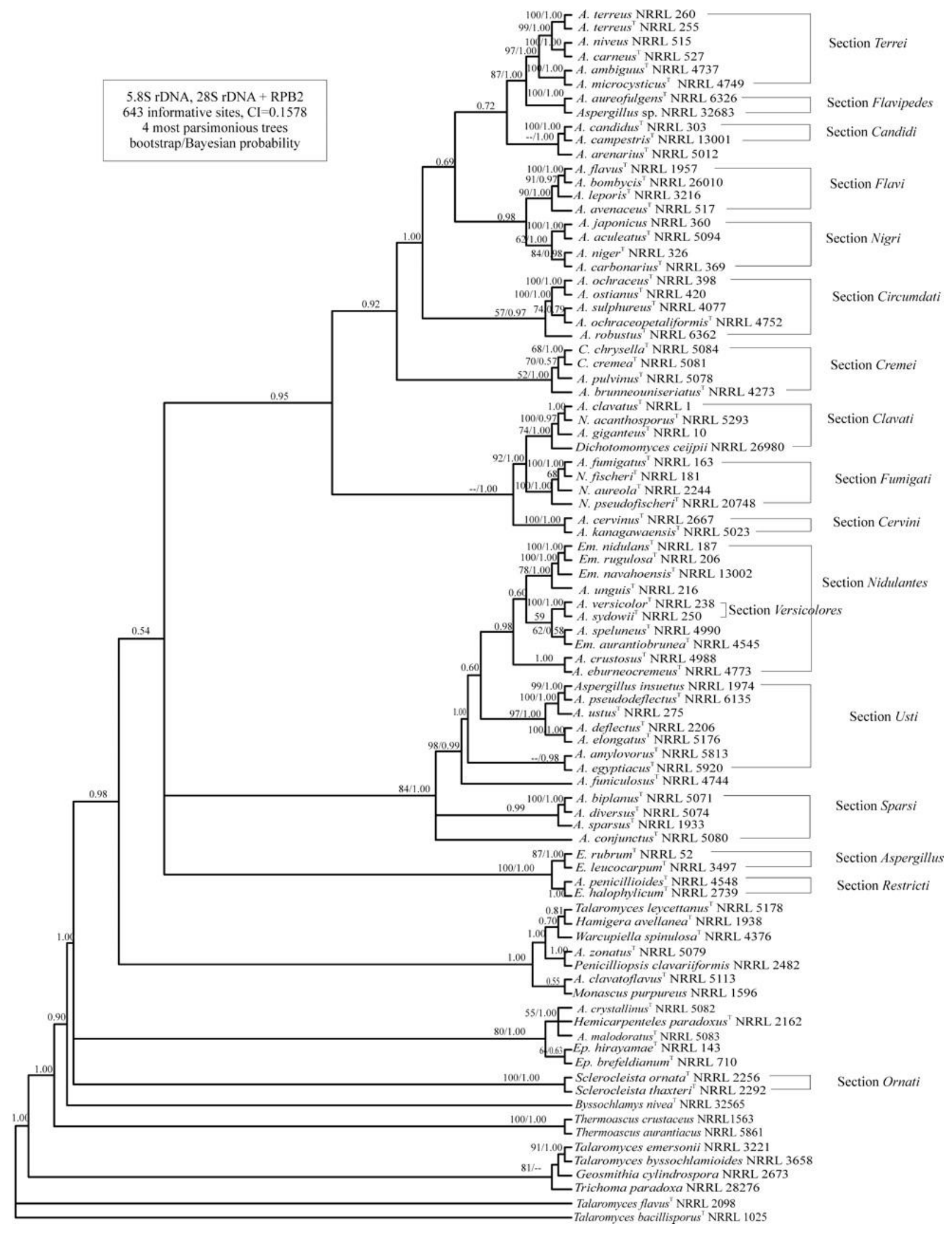

8. ábra. RPB2, 5.8S és 28S rDNS szekvenciákon alapuló MrBayes módszerrel készített konszenzus fa (Peterson 2008). 
Az általunk kapott eredmények szerint a Versicolores, Nidulantes, Aenei, Raperi, Usti, Bispori, Ochraceorosei és Sparsi szekciók alkotnak egy nagy csoportot (Nidulantes alnemzetség). Ezen belül a Nidulantes és Versicolores szekciók ugyan elkülönülnek egymástól, de nem szekciószinten. Chen és munkatársai (2016) a Nidulantes szekcióra fókuszálva végeztek filogenetikai elemzést, az általuk kapott törzsfán a Versicolores szekció tagjai beágyazódnak a Nidulantes szekcióba. Ennek okán nem indokolt a Versicolores szekció megtartása, a korábban ide sorolt fajok ezentúl a Nidulantes szekcióban foglalnak helyet. Peterson és munkatársai (2008) a Circumdati alnemzetségbe sorolják a Cervini, Circumdati, Nigri, Flavi és Cremei szekciókat. A Terrei és Flavipedes szekciókat alnemzetség szintre emelik (Subgenus Terrei). A Candidi szekció is külön alnemzetséget alkot. Eredményeink alapján a Nigri szekció nem a Flavi, hanem a Terrei és Candidi szekciókkal alkot testvércsoportot. A Flavi szekció testvérkládja a Circumdati szekció, a Cremei szekció pedig a távoli Polypaecili, Restricti és Aspergillus szekciókkal mutat rokonságot. A Fumigati, Clavati és Cervini szekciók ebben az esetben is egy közös csoportot alkotnak. De Vries és munkatársai (2017) számos Aspergillus faj teljes genomját hasonlították össze, és szintén arra következtettek, hogy a Circumdati alnemzetség polifiletikus, a Nigri és Flavi szekciók pedig nem testvérkládjai egymásnak. A korábban a Sparsi szekcióba sorolt $A$. funiculosus (Peterson 2008) eredményeink alapján az A. ochraceorosei-vel mutat rokonságot, így inkább tekinthető az Ochraceorosei szekció tagjának. A 8. ábrán szaggatott téglalappal jelölt $A$. arenarius szokatlan helyzete valószínüleg az adott törzs nem megfelelő azonosításának eredménye.

Taylor és munkatársai (2016) azt tapasztalták, hogy az Aspergillus nemzetség nem monofiletikus, ugyanis a Phialosimplex, Polypaecilum és Cristaspora nemzetségek beékelődnek az egyes Aspergillus szekciók közé. Ezért azt a javaslatot tették, hogy az Aspergillus nemzetség esetében a nevezéktant gyökeresen meg kell változtatni, és csak egy szűk csoport tarthatná meg az Aspergillus nevet (subgenus Circumdati), a többi csoportot pedig a jellemző teleomorf nemzetségnevek jelölnék. Egy kutatócsoportunk közremüködésével létrejött tanulmány azonban bizonyítja az Aspergillus nemzetség monofiletikus voltát (Kocsubé és mtsai. 2016). Két független filogenetikai analízis került összehasonlításra 96 és 204 törzset felhasználva, hat és kilenc gén bevonásával (ebben szerepeltek a jelen dolgozatban részletezett munka során generált szekvenciaadatok is). A vizsgált fajok lefedték az Aspergillus nemzetség összes szekcióját, a Penicillium nemzetséget, valamint egyéb nemzetségek képviselőit is bevonták a vizsgálatba az Aspergillaceae, Thermoascaceae és Trichocomaceae családokból. Mindkét vizsgálat egyértelműen bizonyította az Aspergillus nemzetség monofiletikus voltát, 
mind MrBayes, mind ML módszer mellett. A Penicillium nemzetség mindkét filogenetikai fán az Aspergillus nemzetség monofiletikus testvérkládjaként jelent meg, magas támogatottsági értékek mellett. Ebből arra következtethetünk, hogy nincs filogenetikai megalapozottsága annak a javaslatnak, hogy az Aspergillus nemzetséget nevezéktanilag felosszuk, és különböző nemzetségneveket kapjanak az ide tartozó csoportok. Emellett a nemzetség egységességét kemotaxonómiai adatok is alátámasztják (Kocsubé és mtsai. 2016). Az Aspergillus-okkal foglalkozó kutatók körében egyértelmüen többségben vannak azok, akik az Aspergillus név megtartása mellett foglalnak állást (Samson és mtsai. 2017). A Taylor és munkatársai (2016) által javasolt új nevezéktan körülbelül 180 új fajnév létrejöttét eredményezné, szemben az általunk is javasolt megoldással, mely 26 fajnév megváltoztatásával megvalósítható lenne (Samson és mtsai. 2017). Fentiek alapján a Nevezéktani Bizottság (Nomenclature Committee for Fungi, NCF) felé közlésre került azon kérés, hogy a Taylor és munkatársai (2016), valamint a Pitt és Taylor (2016) által közölt publikációkban tett javaslatot elvesse. Információink alapján a Nevezéktani Bizottság az általunk is képviselt javaslatot fogadta el, mely szerint a nemzetség tagjai megőrizhetik az Aspergillus nevet, az idetartozó egyéb fajok pedig, melyek eddig nem rendelkeztek Aspergillus nemzetségnévvel, megkapják azt. 


\section{Az A. niger és $A$. welwitschiae fajok közötti különbség kimutatása UP-PCR analízissel}

Munkánk során a két nagyon közeli csoport, az A. niger és az A. welwitschiae törzsek izolátumainak genetikai variabilitását UP-PCR módszerrel vizsgáltuk. Ez a technika nagyban hasonlít a RAPD-technikához, de az indítószekvenciák hosszabbak, továbbá az indítószekvencia templát DNS-hez való kötődéséhez magasabb hőmérsékletet alkalmazunk, így a RAPD-analízisnél megbízhatóbb, reprodukálható mintázatokat kapunk. A 88 fragmentum figyelembe vételével készített binomiális mátrix alapján létrehozott Neighbour-joining fán az izolátumok két egyértelműen elkülönülő csoportot alkotnak (9. ábra), így elmondhatjuk, hogy az A. niger és az A. welwitschiae izolátumok UP-PCR módszerrel elkülöníthetőek egymástól.

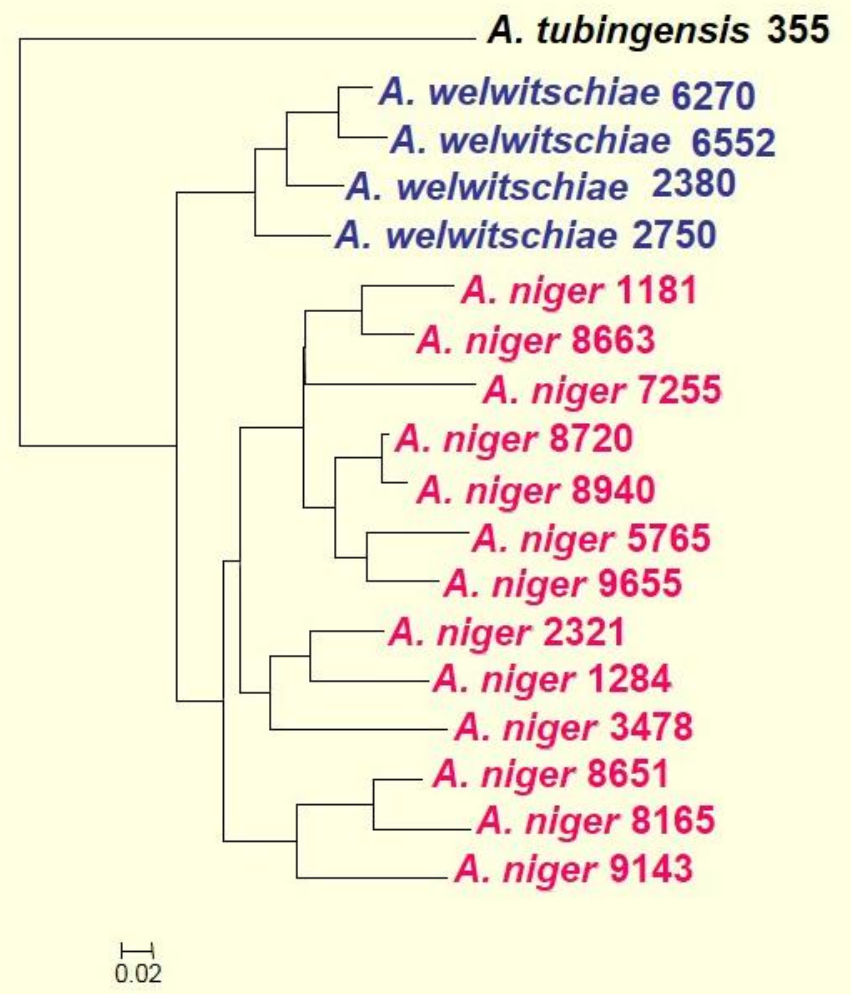

9. ábra. Az A. niger és A. welwitschiae klaszter analízise a UP-PCR profilok alapján

Perrone és munkatársai (2011) azt tapasztalták, hogy az AFLP-módszer is alkalmas az A. niger és az A. welwitschiae csoportok elkülönítésére, tehát megalapozottnak tünik az az állítás, hogy a két csoport között az egyes génszekvenciákban megmutatkozó variabilitás a teljes genomra kiterjed.

A DNS-alapú molekuláris módszereket napjainkban széles körben használják a fajok azonosítására számos gombacsoporton belül. A polifázikus fajkoncepciónak megfelelően azonban arra kell törekednünk, hogy egyéb (morfológiai, fiziológiai stb.) karaktereket is 
keressünk a fajhatárok megállapításánál (Samson és Varga 2009). A termelt metabolitok tekintetében nem sikerült különbséget kimutatni, mindkét csoport termelhet OTA és FB2 mikotoxinokat, ezen kívül piranonigrin A-t, tenzidol B-t, funalenont, malforminokat és nafto$\gamma$-pironokat (Perrone és mtsai. 2011).

Egy korábbi vizsgálatunk alapján bizonyítást nyert, hogy mindkét csoporthoz tartozó izolátumok okozhatnak opportunista mikózisokat a légzőszervrendszerben (ez az anyag nem képezi a disszertáció részét; az eredmény nem került leközlésre). A betegség kialakítása során virulenciafaktor lehet, hogy az adott törzs milyen mértékü elasztáz enzimaktivitással rendelkezik. Ezt követően tüdőmikózisból származó klinikai A. niger és A. welwitschiae izolátumok elasztáz aktivitását vizsgáltuk, és azt tapasztaltuk, hogy az A. niger izolátumok elasztáz aktivitása szignifikánsan alacsonyabb volt, mint az A. welwitschiae izolátumoké $\left(\chi^{2}=8.017 ; \mathrm{p}=0,0046\right)$, azonban az A. niger izolátumok között volt egy kiugróan magas aktivitású törzs (Varga és mtsai. 2010).

\section{Fekete Aspergillus-ok, mint opportunista humán patogének}

\section{Fülfertözésekböl származó fekete Aspergillus izolátumok fajszintü azonosítása}

Munkánk során 7 iráni és 14 magyarországi fülfertőzésből származó izolátumot vizsgáltunk, melyeket kivétel nélkül A. niger-ként azonosítottak a hagyományos, morfológián alapuló módszerrel (5. táblázat). A kalmodulin gén egy szakaszának bázissorrendje alapján elvégeztük az izolátumok fajszintü besorolását. A Maximum Parszimónia módszerrel készített filogenetikai analízis eredményét a 10. ábra szemlélteti, melyen mind a magyarországi, mind az iráni izolátumok láthatóak. Az iráni izolátumok közül 4 az A. niger, 2 az A. tubingensis, 1 pedig az A. welwitschiae faj képviselőjének bizonyult. A Magyarországon izolált minták közül 11 az A. welwitschiae, míg 3 az A. tubingensis fajhoz tartozott, A. niger-t egy esetben sem azonosítottunk.

Az A. niger-t tartják a gombás fülfertőzések egyik leggyakoribb okozójának a világ minden táján (Vennewald és Klemm 2010; Zarei és mtsai. 2010; Bonifaz és mtsai. 2010). Azonban az Aspergillus nemzetség Nigri szekciójába tartozó fajok nagy része nem különböztethető meg egymástól pusztán morfológiai, vagy fiziológiai karakterek alapján (Samson és mtsai. 2007). Munkánk során először azonosítottunk fülfertőzésből származó fekete Aspergillus izolátumokat molekuláris módszerrel, mely a kalmodulin gén egy szakaszának szekvencia-analízisén alapult, hiszen ez a génszakasz már korábban alkalmasnak bizonyult a fekete Aspergillus fajok elkülönítésére (Samson és mtsai. 2007). Eredményeink alapján az A. niger mellett az A. welwitschiae és az A. tubingensis fajok is okozhatnak fülfertőzéseket. 
5. táblázat: Fülfertőzésekböl származó fekete Aspergillus izolátumok

\begin{tabular}{|c|c|c|c|c|}
\hline Izolátum & Nem & Kor & Származás & Faj \\
\hline 26189 & Nő & 54 & Magyarország & A. welwitschiae \\
\hline 29652 & Nő & 61 & Magyarország & A. welwitschiae \\
\hline 31506 & Férfi & 36 & Magyarország & A. welwitschiae \\
\hline 36798 & Nő & 83 & Magyarország & A. welwitschiae \\
\hline 44394 & Nő & 46 & Magyarország & A. tubingensis \\
\hline 59908 & Nő & 53 & Magyarország & A. welwitschiae \\
\hline 65051 & Férfi & 16 & Magyarország & A. welwitschiae \\
\hline 68761 & Nő & 64 & Magyarország & A. welwitschiae \\
\hline 74151 & Férfi & 41 & Magyarország & A. welwitschiae \\
\hline 79661 & Nö & 75 & Magyarország & A. tubingensis \\
\hline 82075 & Férfi & 36 & Magyarország & A. welwitschiae \\
\hline 94839 & Nö & 65 & Magyarország & A. welwitschiae \\
\hline 100065 & Nő & 36 & Magyarország & A. welwitschiae \\
\hline 104280 & Nö & 61 & Magyarország & A. tubingensis \\
\hline 1 & Nő & 26 & Irán & A. niger \\
\hline $1 / 1$ & Nö & 32 & Irán & A. tubingensis \\
\hline 2 & Férfi & 38 & Irán & A. niger \\
\hline $2 / 1$ & Nö & 29 & Irán & A. tubingensis \\
\hline 3 & Férfi & 42 & Irán & A. niger \\
\hline 4 & Férfi & 40 & Irán & A. welwitschiae \\
\hline $4 / 1$ & Férfi & 36 & Irán & A. niger \\
\hline
\end{tabular}




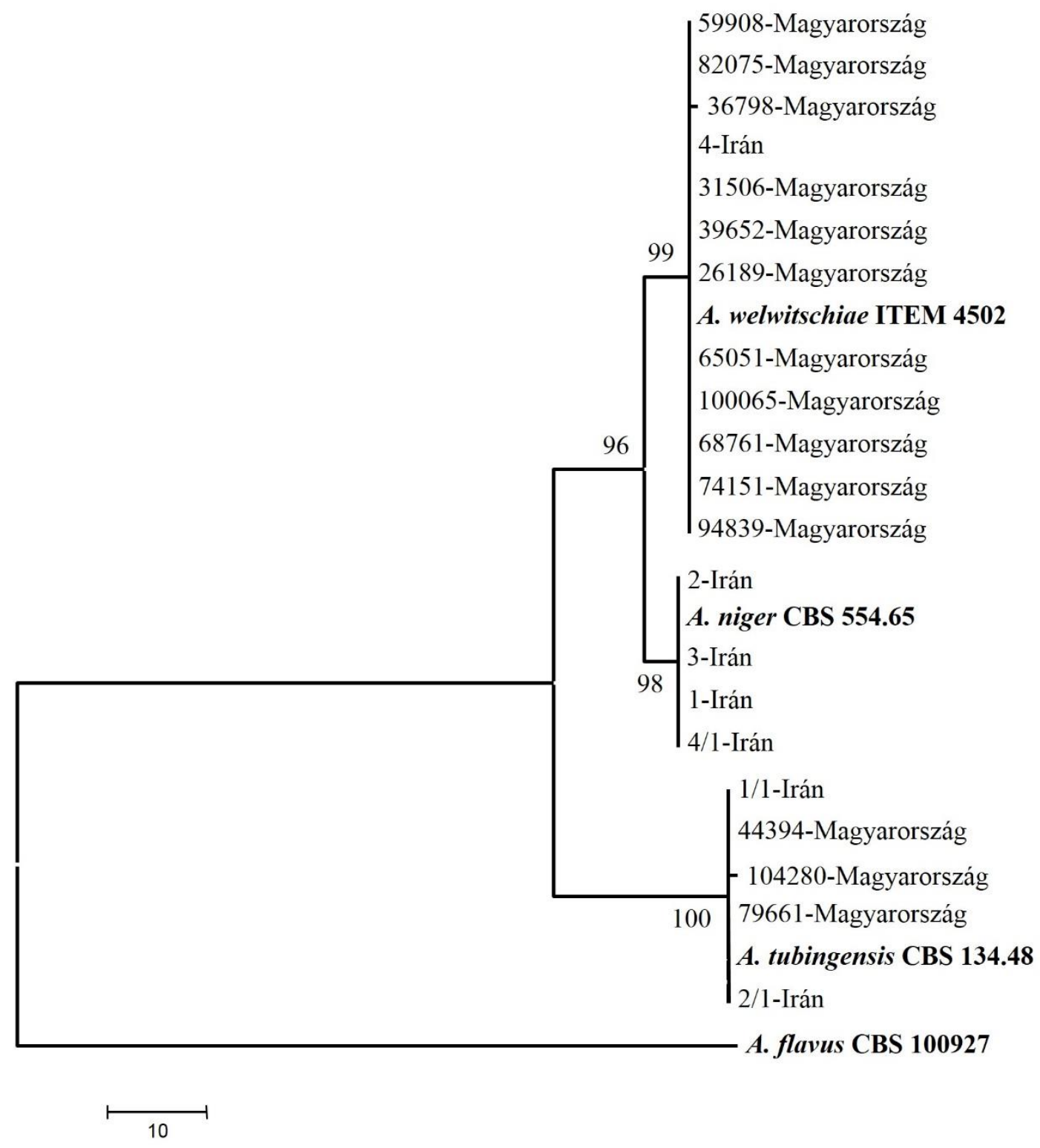

10. ábra. Kalmodulin gén egy szakaszán alapuló filogenetikai fa az iráni és magyarországi fülfertőzésekből származó izolátumokkal

Fülfertő̃zésekböl származó fekete Aspergillus izolátumok antifungális szerekkel szembeni érzékenysége

Az iráni izolátumok közül három törzs érzékenységét vizsgáltuk öt, a klinikumban széles körben használt gombaellenes szerrel (flukonazol, itrakonazol, ketokonazol, terbinafin, amfotericin B) szemben, leveshigításos mikrodilúciós módszert alkalmazva. Az érzékenységet a teljes gátlást okozó minimális gátló koncentráció ( $\mathrm{MIC}_{100}$ ) értékek alapján határoztuk meg (6. táblázat). Mindhárom izolátum rezisztensnek bizonyult flukonazollal szemben $\left(\mathrm{MIC}_{100}>64\right.$ $\mu \mathrm{g} / \mathrm{ml})$, így ennek a szernek a hatását a Magyarországról származó izolátumokra már nem 
vizsgáltuk. A hazai izolátumok közül 4 A. welwitschiae és 2 A. tubingensis izolátum érzékenységét vizsgáltuk. A $\mathrm{MIC}_{100}$-értékek alapján nem mutatkozott jelentős különbség az eltérő fajok érzékenységében, de elmondhatjuk, hogy a terbinafin $\left(\mathrm{MIC}_{100}: 0.25-1 \mu \mathrm{g} / \mathrm{ml}\right)$ és itrakonazol ( $\mathrm{MIC}_{100}: 0.5-1 \mu \mathrm{g} / \mathrm{ml}$ ) hatásosabbnak bizonyultak, mint a ketokonazol (MIC 100 : 8$16 \mu \mathrm{g} / \mathrm{ml} ; 11$. ábra). Az amfotericin B-vel szemben a magyarországi izolátumok érzékenyebbek voltak, mint az iráni izolátumok, ennek okát nem ismerjük.

6. táblázat: Fülfertőzésekből származó izolátumok antifungális szerekkel szembeni érzékenysége

\begin{tabular}{|c|c|c|c|c|}
\hline \multirow{2}{*}{ Törzs } & \multicolumn{4}{|c|}{ MIC100-értékek ( $\mu \mathrm{g} / \mathrm{ml})$} \\
\hline & Itrakonazol & Ketokonazol & Terbinafin & Amfotericin B \\
\hline $\begin{array}{c}\text { A. welwitschiae } \\
26189\end{array}$ & 0,5 & 8 & 0,5 & 0,5 \\
\hline $\begin{array}{c}\text { A. welwitschiae } \\
36798\end{array}$ & 0,5 & 8 & 0,25 & 1 \\
\hline $\begin{array}{c}\text { A. welwitschiae } \\
59908\end{array}$ & 0,5 & 8 & 0,25 & 0,5 \\
\hline $\begin{array}{c}\text { A. welwitschiae } \\
82075\end{array}$ & 0,5 & 8 & 0,5 & 1 \\
\hline $\begin{array}{c}\text { A. tubingensis } \\
44394\end{array}$ & 0,5 & 8 & 1 & 0,5 \\
\hline $\begin{array}{c}\text { A tubingensis } \\
79661\end{array}$ & 0,5 & 16 & 1 & 0,5 \\
\hline $\begin{array}{c}\text { A. welwitschiae } \\
\text { Irán (4) }\end{array}$ & 2 & 16 & 1 & $8-16$ \\
\hline $\begin{array}{l}\text { A. niger } \\
\text { Irán (1) }\end{array}$ & 2 & 32 & 1 & 4 \\
\hline $\begin{array}{l}\text { A. tubingensis } \\
\text { Irán }(2 / 1)\end{array}$ & 1 & 8 & 2 & 8 \\
\hline
\end{tabular}

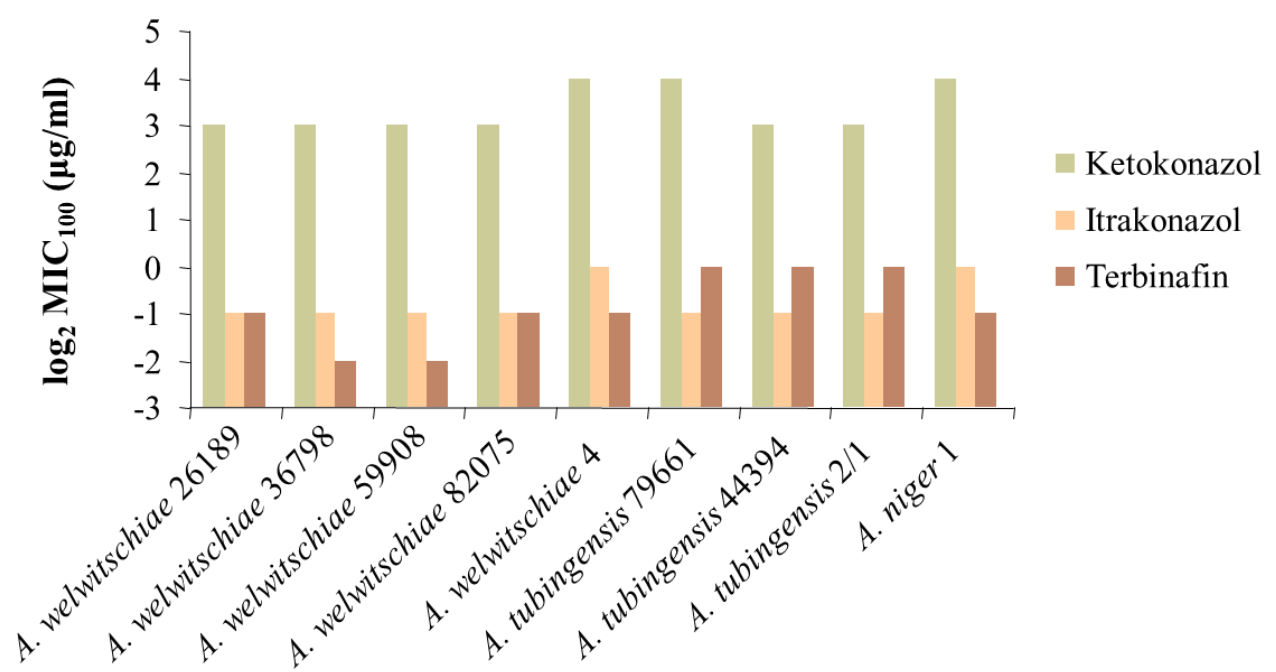

11. ábra. Fülfertőzésekből származó izolátumok érzékenysége antifungális szerekkel szemben 
Yenisehirli és munkatársai (2009) otomikózisból származó izolátumok érzékenységét vizsgálták különböző azolokkal szemben, és hasonlóan az általunk kapott eredményekhez, azt tapasztalták, hogy az összes vizsgált Aspergillus izolátum rezisztens volt flukonazolra. Ugyanezt figyelték meg Kredics és munkatársai (2009) szemfertőzésekből származó A. tubingensis törzsek esetén is. Az általunk vizsgált izolátumok érzékenysége magas volt terbinafinnel szemben. Korábbi munkák is megerősítik, hogy a fekete Aspergillus izolátumok érzékenyek terbinafinra (Alcazar-Fuoli és mtsai. 2009; Karaarslan és mtsai. 2004; Moore és mtsai. 2001). Az itrakonazol esetében 0,5-2 $\mu \mathrm{g} / \mathrm{ml}$-es $\mathrm{MIC}_{100}$ értékeket tapasztaltunk. A szakirodalomban eltérő információkat találunk az A. niger itrakonazollal szembeni érzékenységére vonatkozóan. Yenisehirli és munkatársai (2009) $\mathrm{MIC}_{100} \leq 1 \mu \mathrm{g} / \mathrm{ml}$ értékeket tapasztaltak ennek az antifungális szernek az esetében. Karaarslan és munkatársai (2004) 0,125$1 \mu \mathrm{g} / \mathrm{ml}$-es $\mathrm{MIC}_{100}$-értékeket állapítottak meg itrakonazol vonatkozásában. Kaya és Kiraz (2007) eredményei alapján otomikózisból származó A. niger törzsek rezisztensnek bizonyultak itrakonazollal szemben. Pagiotti és munkatársai (2011) is alacsony antifungális aktivitást tulajdonítottak az itrakonazolnak A. niger-rel szemben $\left(\mathrm{MIC}_{100}>16 \mu \mathrm{g} / \mathrm{ml}\right)$. A vizsgált izolátumok ketokonazollal szemben alacsony érzékenységet mutattak $\left(\mathrm{MIC}_{100}=8-32 \mu \mathrm{g} / \mathrm{ml}\right)$. Ezzel szemben Kredics és munkatársai (2009) szemfertőzésekből származó A. tubingensis izolátumok vizsgálata során alacsonyabb MIC-értékeket tapasztaltak $(0,5-1 \mu \mathrm{g} / \mathrm{ml})$. Aktas és Yigit (2009) 0,25-4 $\mu \mathrm{g} / \mathrm{ml}$-es értékeket írtak le A. niger-ként azonosított izolátumoknál.

A magyarországi izolátumok esetében alacsony $\mathrm{MIC}_{100}$-értékeket tapasztaltunk amfotericin B vonatkozásában. Ez összhangban van több korábbi munkában megfigyelt eredménnyel is (Kaya és Kiraz 2007; Moore és mtsai. 2001). Alcazar-Fuoli és munkatársai (2009) 0,12-0,28 $\mu \mathrm{g} / \mathrm{ml} \mathrm{MIC}_{100}$-értékeket írtak le A. niger és A. tubingensis törzsekre, Pagiotti és munkatársai (2011) azonban $\mathrm{MIC}_{100} \geq 8 \mu \mathrm{g} / \mathrm{ml}$ értékeket figyeltek meg, mely eredmény az általunk mért, iráni izolátumoknál tapasztalt értékekkel áll összhangban. Eredményeink és az irodalmi adatok összevetése alapján elmondható, hogy a fekete Aspergillus izolátumok amfotericin B-vel szembeni érzékenysége igen széles skálán mozog, mely nincs összefüggésben azzal, hogy az adott izolátum melyik fajhoz tartozik. 
Fekete Aspergillus-ok, mint potenciális fumonizintermelők előfordulása élelmiszerekben Fekete Aspergillus-ok elöfordulása és eloszlása mazsolamintákon

Munkánk során 13 mazsolaminta mikobiótáját vizsgáltuk. Mintáink Törökországból, Dél-Afrikából, Görögországból, Iránból, az Amerikai Egyesült Államokból, Kínából és Indiából származtak. A 13 mintából 11 erősen szennyezett volt fekete Aspergillus-okkal, és ezekben az esetekben a szennyezettség jellemző volt a mazsolaszemek felszínén. A mintákról összesen 72 fekete Aspergillus törzset izoláltunk. PCR-RFLP analízis során elöször PCRtechnika segítségével felszaporítottuk az izolátumok ITS-régióját, majd a kapott terméket $R s a \mathrm{I}$ restrikciós endonukleázzal emésztettük. A 72 izolátum közül 35 tartozott a $\mathrm{N}$ típushoz, mely csoportba az A. niger fajkomplex tagjai tartoznak, a többi izolátum a T típushoz tartozott, mely az A. tubingensis-t és közeli rokon fajait foglalja magában. Jelenlegi ismereteink alapján a T típushoz tartozó törzsek nem képesek mikotoxinok termelésére (Samson és mtsai. 2007), ezért ezeket az izolátumokat nem vizsgáltuk tovább. A 11 erősen szennyezett mintából 2-2 kínai és török, illetve 1-1 indiai és iráni minta esetében a T típusba tartozó törzsek domináltak ( 7 . táblázat). Az $\mathrm{N}$ típushoz tartozó törzsek esetében a fajszintü azonosításhoz felszaporítottuk a kalmodulin gén egy szakaszát, meghatároztuk a kapott PCR-termékek bázissorrendjét, majd Maximális Parszimónia módszer alkalmazásával filogenetikai analízist végeztünk. Az adatállomány 361 karakteréből 151 volt parszimónia-informatív. Az analízis 197 maximálisan parszimónikus fát eredményezett (hossz: 467, konziszteciaindex: 0,5967, retenciós index: 0,8638), melyek közül az egyiket az 12. ábra szemlélteti. Eredményeink alapján az izolátumok legnagyobb része ( $\mathrm{n}=30)$ az $A$. niger és az $A$. welwitschiae fajhoz tartozott, melyek mikotoxinok termelésére képesek lehetnek. A fennmaradó 5 izolátum közül 2 A. carbonarius-nak, 3 pedig A. uvarum-nak bizonyult. Az A. uvarum fajt eddig kizárólag szőlőből, illetve szőlőt tartalmazó termékekböl sikerült izolálni (Perrone és mtsai. 2008). 
7. táblázat: A vizsgált mazsolaminták és a róluk izolált fekete Aspergillus-ok

\begin{tabular}{ccccc}
\hline $\begin{array}{c}\text { Minta } \\
\text { sorszáma }\end{array}$ & Származás (vásárlás) helye & $\begin{array}{c}\text { Fekete } \\
\text { Aspergillus } \\
\text { izolátumok } \\
\text { száma }\end{array}$ & $\begin{array}{c}\text { N típushoz } \\
\text { tartozó } \\
\text { izolátumok }\end{array}$ & $\begin{array}{c}\text { Azonosított fajok (izolátumok } \\
\text { száma) }\end{array}$ \\
\hline 1 & Kalifornia (Florida) & 5 & 5 & $\begin{array}{c}\text { A. niger (5) } \\
\text { A. niger (7) }\end{array}$ \\
2 & Kalifornia (Florida) & 8 & 7 & A. welwitschiae (6), A. uvarum (2), \\
3 & Nem ismert (Hollandia) & 11 & 9 & A. carbonarius $(1)$ \\
4 & Törökország (Hollandia) & 7 & 3 & A. welwitschiae (3) \\
5 & Kína (Magyarország) & 9 & 1 & A. carbonarius $(1)$ \\
6 & Törökország (India) & 8 & 6 & A. welwitschiae (3), A. niger $(2)$, A. \\
7 & Törökország (Törökország) & 10 & 3 & uvarum $(1)$ \\
8 & India (India) & 1 & 1 & A. niger $(1)$ \\
9 & Kína (Magyarország) & 3 & - & - \\
10 & Irán (Magyarország) & 6 & - & - \\
11 & India (India) & 4 & - & - \\
12 & Dél-Afrika (Hollandia) & - & - & - \\
13 & Törökország (Hollandia) & - & - & - \\
\hline
\end{tabular}




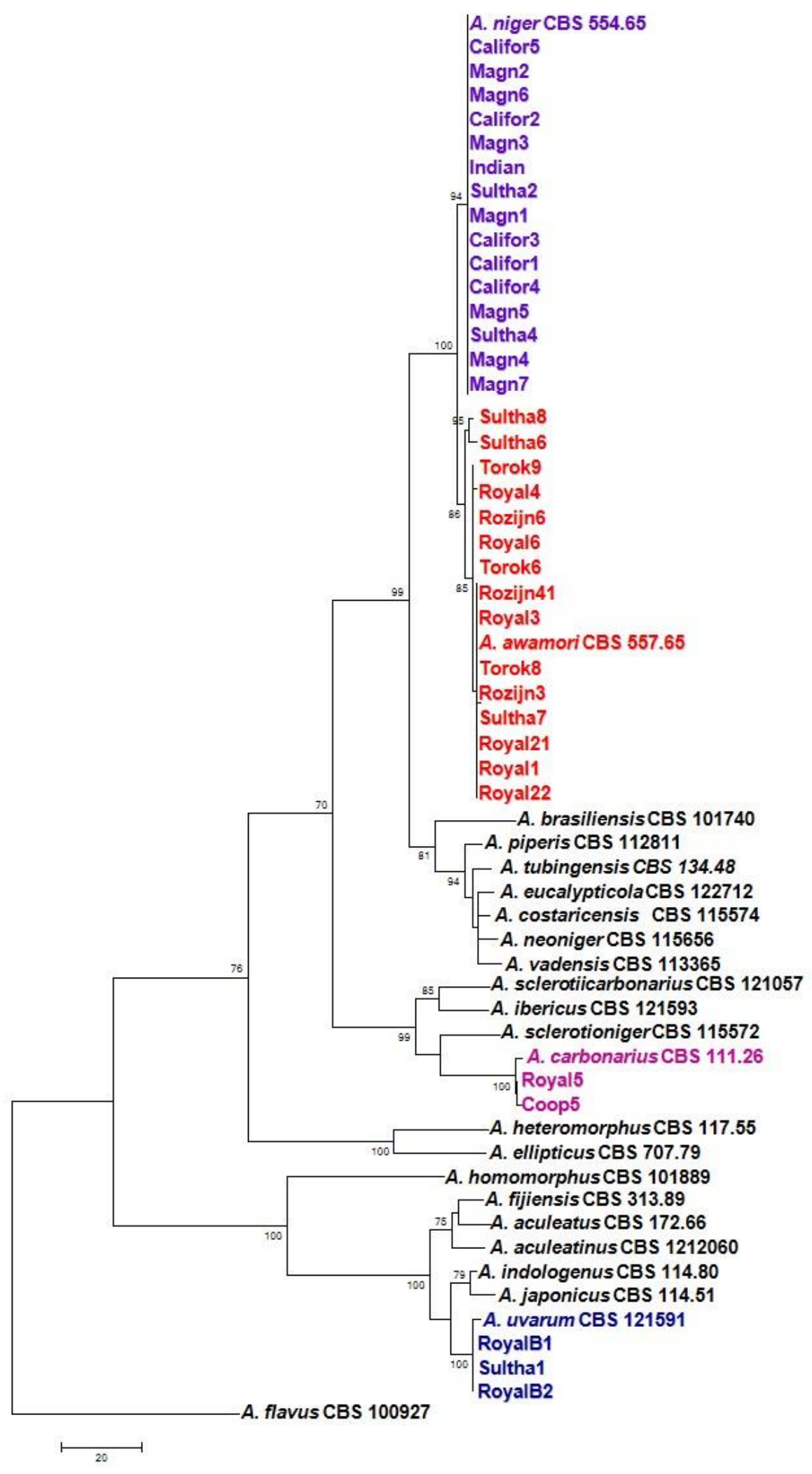

12. ábra. Kalmodulin gén egy szakaszán alapuló filogenetikai fa

Fekete Aspergillus-ok közé tartozó típustörzsekkel, valamint a mazsolamintákról származó izolátumokkal. Az ágakon láthatók a 70\%-nál magasabb bootstrap értékek. Az ábrán a CBS 557.65 számú törzs még a korábbi $A$. awamori nevet viseli, a törzs jelenlegi neve $A$. welwitschiae. 
A mazsolaminták fumonizintartalmát RP-HPLC/ESI-ITMS-technika segítségével mértük. Hét mintát választottunk, melyek esetében előzetesen tapasztaltuk lehetséges fumonizintermelő fekete Aspergillus-ok (A. niger vagy A. welwitschiae) jelenlétét. Minden minta esetében sikerült detektálnunk fumonizineket. A mazsolamintákban 10 különböző fumonizin izomer fordult elő, ezek a következők: $\mathrm{FB}_{1}$, izo-FB $1, \mathrm{FB}_{2}, \mathrm{FB}_{3}, 3$-epi-FB 3 , FB 4 , 3epi-FB 4 , izo-FB $2,3, \mathrm{FB}_{5}$, izo-FB 5 (8. táblázat). A minták fumonizintartalma 4,55 és 35,49 mg/kg között változott, az átlag 7,22 mg/kg volt.

Az Európai Bizottság 1126/2007/EK rendeletében a $\mathrm{FB}_{1^{-}}$és $\mathrm{FB}_{2}$-tartalomra vonatkozóan határértékeket állapítanak meg, azonban ezek a határértékek kizárólag kukoricaalapú termékekre vonatkoznak. A rendelet a legmagasabb határértéket (4 mg/kg) feldolgozatlan kukorica esetében állapítja meg, a legalacsonyabbat $(0,2 \mathrm{mg} / \mathrm{kg})$ pedig csecsemők és kisgyermekek számára készült kukoricaalapú élelmiszerek esetében. A mazsolára vonatkozóan ugyan nincs megállapított határérték a fumonizin-tartalomra, figyelmet érdemel az a tény, hogy az általunk vizsgált mazsolaminták átlagos fumonizintartalma a feldolgozatlan kukoricára vonatkozó határérték közel 2-szerese volt, az egyik Kaliforniából származó mintában pedig a határérték 9-szeresének megfelelő mennyiségü fumonizint detektáltunk.

8. táblázat: Mazsolaminták fumonizintartalma

\begin{tabular}{|c|c|c|c|c|c|c|c|c|c|c|c|}
\hline \multirow{2}{*}{$\begin{array}{c}\text { Minta } \\
\text { sorszáma }\end{array}$} & \multicolumn{11}{|c|}{ Detektált fumonizin izomerek mennyisége $(\mu \mathrm{g} / \mathrm{kg})$} \\
\hline & $\mathrm{FB}_{1}$ & $\mathrm{FB}_{3}$ & $\begin{array}{c}\text { 3-epi- } \\
\mathrm{FB}_{4}\end{array}$ & $\mathrm{FB}_{4}$ & $\mathrm{FB}_{2}$ & $\begin{array}{l}\text { izo- } \\
\text { FB5 }\end{array}$ & $\mathrm{FB}_{5}$ & $\begin{array}{c}\text { 3-epi- } \\
\mathrm{FB}_{3}\end{array}$ & $\begin{array}{l}\text { izo- } \\
\mathrm{FB}_{1}\end{array}$ & $\begin{array}{c}\text { izo- } \\
\mathrm{FB}_{2,3}(1)\end{array}$ & $\begin{array}{c}\text { Összes } \\
\text { FB }\end{array}$ \\
\hline 1 & 17321,5 & 3716,03 & 673,10 & 1483,92 & 11515,78 & 11,99 & 43,80 & 489,93 & 68,08 & 163,40 & 35487,5 \\
\hline 2 & 243,42 & 55,05 & - & 59,58 & 325,63 & - & - & - & - & - & 683,68 \\
\hline 3 & 247,38 & 50,27 & - & - & 157,14 & - & - & - & - & - & 454,79 \\
\hline 4 & 358,18 & 106,84 & 48,46 & 84,50 & 424,60 & - & - & - & - & - & 1022,58 \\
\hline 6 & 502,85 & 236,11 & 98,09 & 236,20 & 1055,95 & - & - & - & - & - & 2129,20 \\
\hline 7 & 299,33 & 122,50 & 30,19 & 94,19 & 379,15 & - & - & - & - & - & 925,36 \\
\hline 8 & 1491,18 & 489,95 & 179,22 & 425,61 & 2095,40 & - & - & 62,38 & - & - & 4755,74 \\
\hline
\end{tabular}

\section{Mazsoláról származó fekete Aspergillus izolátumok fumonizintermelö képessége}

Összesen 30 A. niger és A. welwitschiae izolátum fumonizintermelő képességét vizsgáltuk, melyek közül 20 izolátum esetében tapasztaltuk különböző fumonizin izomerek jelenlétét, ez az izolátumok 66\%-ának felel meg (9. táblázat). Az A. niger izolátumok 80\%-a, míg az A. welwitschiae izolátumok 53.3\%-a bizonyult képesnek fumonizinek termelésére. Noonim és munkatársai (2009) kávéról izolált A. niger izolátumok vizsgálata során azt 
tapasztalták, hogy az izolátumok 76\%-a volt képes fumonizineket előállítani. Mogensen és munkatársai (2010) szőlőről és mazsoláról izoláltak A. niger törzseket, melyeknek 77\%-a termelt fumonizineket. Az eddigi irodalmi adatok alapján az A. niger faj $\mathrm{FB}_{2}$ (Frisvad és mtsai. 2007), $\mathrm{FB}_{4}$ (Noonim és mtsai. 2009) és izo-FB 1 (FB; ; Mansson és mtsai. 2010) termelésére való képessége nyert bizonyítást. $\mathrm{A} \mathrm{FB}_{1}, \mathrm{FB}_{3}, 3$-epi-FB 3 , 3-epi-FB 4 és izo-FB 2,3 izomereket elsőként azonosítottuk, mint fekete Aspergillus-ok által termelt fumonizinek (13. ábra). Egyik izolátum sem termelte az egyik mazsolamintában detektált $\mathrm{FB}_{5}$ és izo-FB5 izomereket. Ennek több oka lehet. Elöfordulhat, hogy az izomereket termelö Aspergillus törzset nem izoláltuk, vagy az általunk használt táptalajon (CYA20S) nem termelte ezeket az izomereket. Annak a lehetőségét sem zárhatjuk ki, hogy az említett izomereket tartalmazó mazsolaminta Fusarium-mal is szennyezett volt. A vizsgált izolátumok 0,017-19,6 mg/kg mennyiségü fumonizint termeltek, átlagosan 5,16 mg/kg-t. Az A. welwitschiae izolátumok tekintetében az átlagos fumonizintartalom 3,31 mg/kg, míg az A. niger izolátumok esetében $6,39 \mathrm{mg} / \mathrm{kg}$ volt. Mogensen és munkatársai (2010) szőlőről és mazsoláról származó A. niger izolátumok fuminizintermelő képességének vizsgálata során jóval kisebb értékeket tapasztaltak (1-14 $\mu \mathrm{g} / \mathrm{kg}$ ). Szécsi és munkatársai (2010) Magyarországon gyüjtött $F$. verticillioides törzsek fumonizintermelő képességét vizsgálták. Eredményeik alapján a $F$. verticillioides törzsek jóval magasabb mennyiségü fumonizin termelésére képesek, mint az Aspergillus izolátumok, de a szőlőszemek szárításának hatására a fumonizintartalom akkumulálódhat. Frisvad és munkatársai (2007) azt tapasztalták, hogy az A. niger törzsek a $F$. verticillioides törzsekkel ellentétben az alacsony vízaktivitású közegekben termelnek elsősorban fumonizineket. Ez a tény előrevetíti, hogy a mazsola kifejezetten jó táptalaj a fekete Aspergillus-ok fumonizintermeléséhez. Az A. niger borszőlőn gyakran előfordul (Varga és mtsai. 2004), ezért feltehető, hogy a fekete Aspergillus-ok már a szárítást megelőzően jelen vannak a szőlőszemeken. Logrieco és munkatársai (2009) fekete Aspergillus-ok által termelt fumonizin általi szennyezettséget tapasztaltak szőlőminták vizsgálata során. 
9. táblázat: Mazsoláról származó A. niger és A. welwitschiae izolátumok fumonizintermelő képessége

\begin{tabular}{|c|c|c|c|c|c|c|c|c|c|c|}
\hline \multirow[b]{2}{*}{ Izolátum } & \multicolumn{10}{|c|}{ Detektált fumonizin izomerek mennyisége $(\mu \mathrm{g} / \mathrm{kg})$} \\
\hline & $\mathrm{FB}_{1}$ & $\mathrm{FB}_{2}$ & $\begin{array}{c}\text { izo- } \\
\mathrm{FB}_{2,3}(1)\end{array}$ & $\begin{array}{c}\text { izo- } \\
\mathrm{FB}_{2,3}(2)\end{array}$ & $\begin{array}{l}\text { 3-epi- } \\
\mathrm{FB}_{4}\end{array}$ & $\mathrm{FB}_{4}$ & $\mathrm{FB}_{3}$ & $\begin{array}{c}\text { 3-epi- } \\
\mathrm{FB}_{3}\end{array}$ & $\begin{array}{l}\text { izo- } \\
\mathrm{FB}_{1}\end{array}$ & $\begin{array}{c}\text { Összes } \\
\text { FB }\end{array}$ \\
\hline 1.1 & - & 4908,33 & 196,34 & 70,07 & 91,52 & 366,47 & - & - & 260,75 & 5893,48 \\
\hline 1.2 & - & 3109,12 & 98,52 & 37,38 & 161,77 & 335,63 & - & - & 181,48 & 3923,90 \\
\hline 1.3 & 23,03 & 3310,45 & 113,90 & 34,16 & 168,05 & 291,03 & - & - & 189,57 & 4130,19 \\
\hline 1.4 & 28,39 & 246,57 & - & - & - & - & - & - & 19,81 & 294,77 \\
\hline 1.5 & 17,63 & 7153,52 & 226,08 & 69,68 & 143,22 & 418,71 & - & - & 458,22 & 8487,06 \\
\hline 2.1 & 22,30 & 6572,47 & 226,45 & 82,87 & 71,79 & 461,02 & - & - & 333,82 & 7770,72 \\
\hline 2.2 & 13,10 & 6689,70 & 417,95 & 105,96 & 63,69 & 594,05 & - & - & 296,64 & 8181,09 \\
\hline 2.4 & 14,11 & 1562,46 & 63,46 & 21,11 & 26,81 & 153,16 & - & - & 89,33 & 1930,44 \\
\hline 2.5 & 12,57 & 2971,50 & 92,76 & 32,73 & 35,23 & 140,20 & - & - & 221,17 & 3506,16 \\
\hline 2.7 & 17,90 & 4816,58 & 154,19 & 81,34 & 38,48 & 382,27 & - & - & 389,28 & 5880,04 \\
\hline 3.4 & 17,41 & - & - & - & - & - & - & - & - & 17,41 \\
\hline 3.6 & 56,43 & 26,89 & - & - & - & - & - & - & - & 83,32 \\
\hline 4.3 & 19,44 & 24,66 & - & - & - & - & - & - & - & 44,10 \\
\hline 4.4 & 29,21 & 2239,33 & 118,50 & 50,15 & 102,87 & 474,78 & - & - & 85,65 & 3100,42 \\
\hline 6.2 & 27,87 & 7102,55 & 269,88 & 86,16 & 505,10 & 698,28 & - & - & 318,38 & 9008,22 \\
\hline 6.4 & 15,72 & 14350,36 & 458,21 & 133,04 & 832,33 & 1237,79 & - & - & 643,51 & 17670,96 \\
\hline 6.6 & 21,55 & 18,52 & - & - & - & - & - & - & - & 40,07 \\
\hline 6.7 & 2481,39 & 11649,00 & 593,79 & 183,08 & 1541,56 & 2155,48 & 538,49 & 73,36 & 379,49 & 19595,64 \\
\hline 6.8 & 25,62 & 17,47 & - & - & - & - & - & - & - & 43,09 \\
\hline 7.8 & 12,44 & 3239,09 & 21,80 & 12,44 & 4,32 & 27,17 & - & - & 267,49 & 3584,75 \\
\hline
\end{tabular}

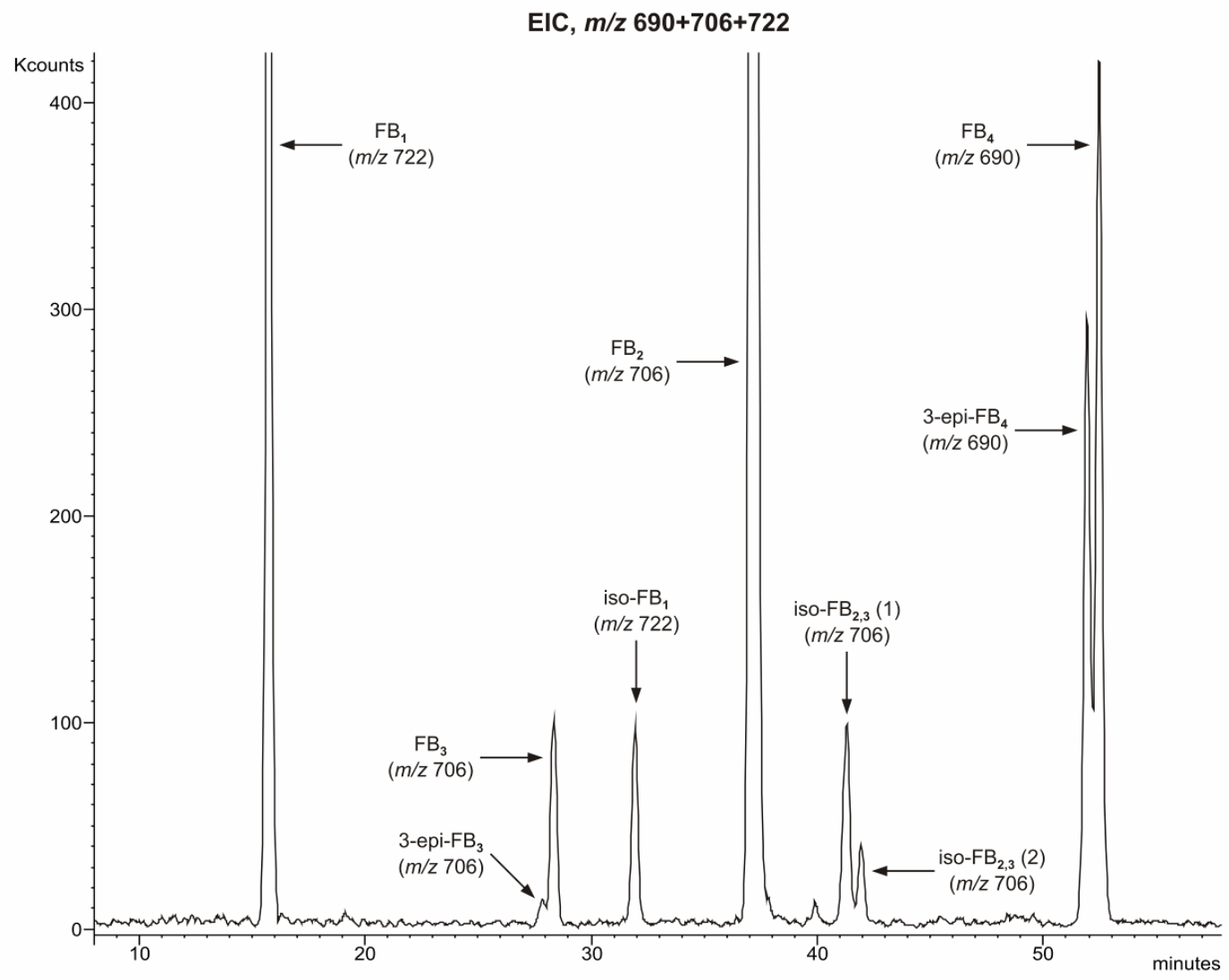

13. ábra. RP-HPLC/ESI-ITMS kromatogram a 6.7-es A. welwitschiae izolátum által termelt fumonizin-izomerekkel 
Következtetésképpen elmondható, hogy az A. niger és $A$. welwitschiae fajok felelősek a mazsola fumonizin-szennyezettségéért világszerte, mely tényt alátámasztja, hogy az A. niger és az A. welwitschiae izolátumok nagy része képes magas cukortartalmú közegben fumonizinek termelésére. 


\section{Fekete Aspergillus izolátumok fügéröl és datolyáról}

Munkánk során vizsgáltuk egyéb aszalt gyümölcsökön előforduló potenciálisan mikotoxin termelő fekete Aspergillus törzsek előfordulását. Munkánkba 5 datolya- és 4 fügemintát vontunk be. A Magyarországon vásárolt gyümölcsök Tunéziából és Iránból származtak (10. táblázat). Mind az öt datolyamintáról, valamint a három fügemintáról sikerült fekete Aspergillus törzseket izolálnunk. Az izolátumok fajszintü azonosításához a kalmodulin gén egy szakaszát felszaporítottuk, majd a szekvenciákat az NCBI GenBank adatbázisában lévő szekvenciákkal vetettük össze. A datolyamintákon kizárólag A. tubingensis fordult elő. Ez a faj eddigi ismereteink alapján mikotoxinok termelésére nem képes. A fügeminták esetében is az $A$. tubingensis faj dominált, de A. niger jelenlétét is kimutattuk. Mivel ez a faj képes lehet fumonizinek termelésére, ezért ebben az esetben felmerül a fügeminták A. niger általi fumonizin-szennyezettségének lehetősége. A vizsgált 3 fügemintából 1 mintában tudtuk fumonizinek jelenlétét kimutatni (14. ábra): Négy különböző fumonizin-izomer volt jelen a mintában, és jóval kisebb koncentrációban, mint azt a mazsolaminták esetében tapasztaltuk (összesen $0,16 \mathrm{mg} / \mathrm{kg} ; 11$. táblázat).

10. táblázat: Datolyáról és fügéről származó fekete Aspergillus izolátumok

\begin{tabular}{cccc}
\hline Minta & Származás helye (minták száma) & $\begin{array}{c}\text { Fekete Aspergillus } \\
\text { izolátumok száma }\end{array}$ & $\begin{array}{c}\text { Azonosított fajok (izolátumok } \\
\text { száma) }\end{array}$ \\
\hline Datolya & Tunézia (2), Irán (3) & 35 & $\begin{array}{c}\text { A. tubingensis (35) } \\
\text { Füge }\end{array}$ \\
Tunézia (2), Irán (2) & 23 & A. tubingensis (17), A. niger (6) \\
\hline
\end{tabular}

11. táblázat: A fügeminta fumonizintartalma

\begin{tabular}{cccccc}
\hline \multirow{2}{*}{ Minta } & \multicolumn{5}{c}{ Detektált fumonizin izomerek mennyisége $(\boldsymbol{\mu g} / \mathbf{k g})$} \\
\cline { 2 - 5 } & $\mathrm{FB}_{1}$ & $\mathrm{FB}_{2}$ & $\mathrm{FB}_{3}$ & $\mathrm{FB}_{4}$ & Összes FB \\
\hline Füge (Irán) & 82,41 & 56,78 & 19,09 & 7,94 & 166,22 \\
\hline
\end{tabular}




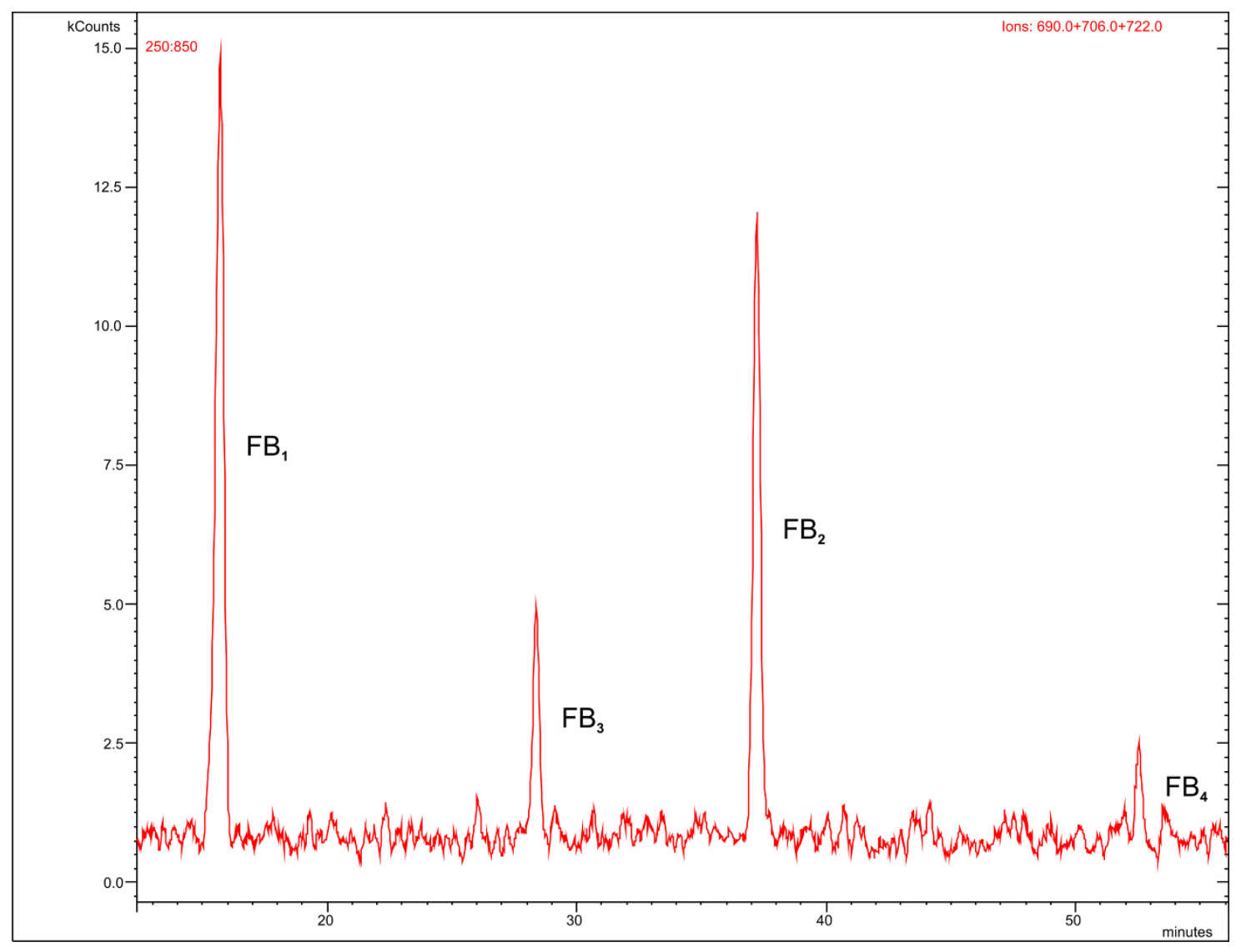

14. ábra. A fügemintában detektált fumonizin-izomerek

\section{Hagymán elöforduló fekete Aspergillus-ok}

Fekete Aspergillus-ok igen gyakran fordulnak elö hagymán, és a növény fekete rothadással járó megbetegedését eredményezik (Varga és mtsai. 2008). Ezen tényből kiindulva kezdtük el hagymaminták vizsgálatát, potenciálisan fumonizintermelö törzsek azonosítása céljából. Hat db Magyarországon vásárolt hagymamintát vontunk be vizsgálatainkba. Egyetlen kivétellel minden mintáról sikeresen izoláltunk fekete Aspergillus törzseket. A fertőzöttség jellemző volt mind a belső húsos, mind a külső száraz leveleken. A fertőzés tünetmentes lehet a teljes érettség eléréséig, ami azt jelzi, hogy a gomba endofitaként jelen van a növényi szövetekben, de nem okoz megbetegedést a fiatal növényben (Lorbeer 2002). Tapasztalataink alapján is elmondható, hogy a fekete Aspergillus-ok jelenléte a hagymamintákban akkor is feltételezhető, ha a fertőzöttség szemmel nem látható. A látható tünetek a tárolás során jelennek meg, és jelentős károkat okozhatnak.

Az izolátumok fajszintű azonosításához felszaporítottuk a kalmodulin gén egy szakaszát, meghatároztuk a kapott PCR-termékek bázissorrendjét, majd Maximális Parszimónia módszer alkalmazásával filogenetikai analízist végeztünk. Az adatállomány 250 
karakteréböl 26 volt parszimónia-informatív. Az analízis 653 maximálisan parszimónikus fát eredményezett (hossz: 81, konzisztecia index: 0,74419, retenciós index: 0,9052), melyek közül az egyiket az 15. ábra szemlélteti. Eredményeink alapján mind a 35 izolátum az A. welwitschiae fajhoz tartozott.

Különböző országokból (Magyarország különböző területei, Lengyelország, Anglia, USA, India) származó hagymamintákat gyüjtöttünk, melyekről összesen 70 fekete Aspergillus törzset izoláltunk. Ezeket egy, a kutatócsoportunk által tervezett fajspecifikus primerpár segítségével azonosítottuk, mely egyértelműen alkalmas az A. niger és $A$. welwitschiae törzsek elkülönítésére (Gherbawy és mtsai. 2015). Az izolált törzsek mindegyike A. welwitschiae-nek bizonyult. Számos korábbi munkában említést tesznek arról, hogy a hagymán leggyakrabban előforduló penészgombafaj az A. niger (Walker és Lindegren 1924; Curtis és mtsai. 1974; Tyson és Fullerton 2004), azonban ezekben az esetekben a fajazonosítás morfológiai karakterek alapján történt. Mivel az A. niger és A. welwitschiae törzsek morfológiai alapon nem különíthetőek el egymástól, így valószínüsíthető, hogy ezek az izolátumok is az A. welwitschiae fajhoz tartoztak. Gherbawy és munkatársai (2015) 40 hagymamintáról izoláltak 60 penészgombatörzset. Harminchét hagymáról fekete Aspergillus-okat (összesen 37 törzset), melyek azonosítását a kalmodulin génszekvenciák alapján végezték, és hasonlóan az általunk megfigyelt eredményekhez, azt tapasztalták, hogy a hagymáról származó fekete Aspergillus izolátumok kivétel nélkül az A. welwitschiae fajhoz tartoztak. Hagymából készített kivonatok növekedésgátló hatását figyeltük meg az A. niger törzsek esetében, míg ez a gátló hatás az $A$. welwitschiae törzsek esetében nem mutatkozott (nem publikált adat). 


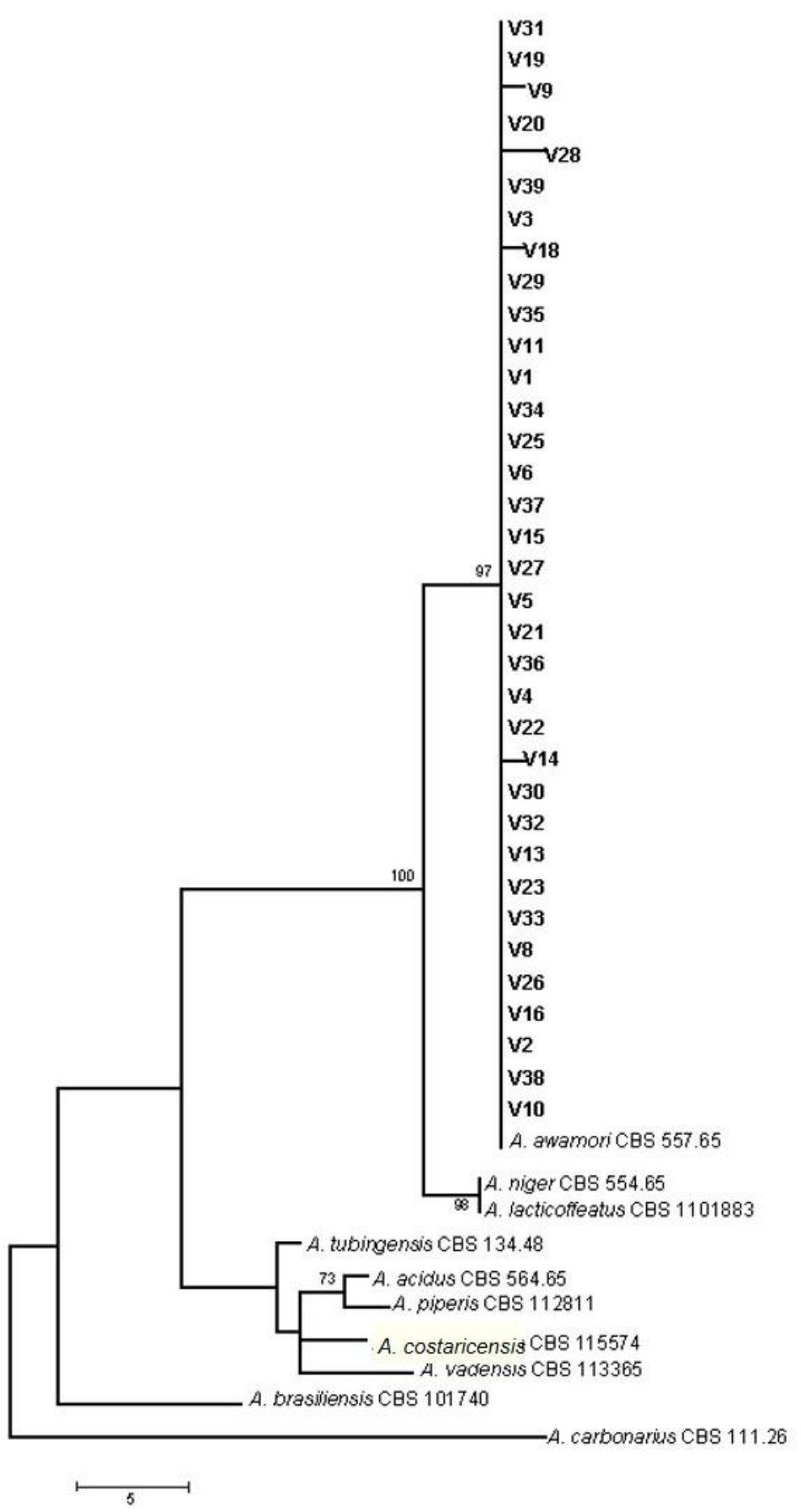

15. ábra. Kalmodulin gén egy szakaszán alapuló filogenetikai fa

Fekete Aspergillus-ok közé tartozó típustörzsek, valamint a hagymamintákról származó izolátumok. Az ágakon láthatók a 70\%-nál magasabb bootstrap-értékek. Az ábrán a CBS 557.65 számú törzs még a korábbi $A$. awamori nevet viseli, a törzs jelenlegi neve $A$. welwitschiae. 
Összesen 59 izolátum fumonizin- és ochratoxintermelő képességét vizsgáltuk. A törzsek 15\%-a (9/59) volt képes fumonizinek, míg 17\%-a (10/59) OTA termelésére (12. táblázat). Ezek közül összesen egy olyan törzs volt, amelyik fumonizineket és OTA-t egyránt termelt.

12. táblázat: Hagymamintákról származó A. welwitschiae törzsek mikotoxintermelő képessége

\begin{tabular}{|c|c|c|}
\hline Törzs & $\begin{array}{c}\text { FumonizinB } \\
(\mu \mathrm{g} / \mathrm{kg})\end{array}$ & $\begin{array}{c}\text { OTA } \\
(\mu \mathrm{g} / \mathrm{kg})\end{array}$ \\
\hline V1 & - & - \\
\hline V2 & - & - \\
\hline V3 & - & - \\
\hline V4 & 11586,6 & - \\
\hline V5 & - & - \\
\hline V6 & - & - \\
\hline V8 & - & - \\
\hline V9 & - & - \\
\hline V10 & - & 356,232 \\
\hline V11 & 13134,1 & - \\
\hline V12 & - & - \\
\hline V13 & - & - \\
\hline V14 & - & - \\
\hline V15 & - & - \\
\hline V16 & - & - \\
\hline V17 & - & 153,914 \\
\hline V18 & 8634 & - \\
\hline V19 & - & - \\
\hline V20 & - & - \\
\hline V21 & - & - \\
\hline V23 & - & - \\
\hline V24 & - & - \\
\hline V24 & - & - \\
\hline V25 & - & - \\
\hline V26 & - & 602,946 \\
\hline V27 & - & - \\
\hline V28 & - & - \\
\hline V29 & - & - \\
\hline V30 & - & - \\
\hline V31 & - & - \\
\hline V32 & - & - \\
\hline V33 & - & - \\
\hline V34 & - & - \\
\hline V35 & 6986,7 & - \\
\hline V36 & - & - \\
\hline V37 & - & - \\
\hline V38 & - & - \\
\hline V39 & - & - \\
\hline I1 a & 2844,5 & - \\
\hline $\mathrm{I} 1 \mathrm{~b}$ & - & 163,696 \\
\hline $\mathrm{J} 1 \mathrm{a}$ & - & 21,664 \\
\hline $\mathrm{J} 1 \mathrm{c}$ & - & 28,08 \\
\hline
\end{tabular}




\begin{tabular}{ccc}
\hline Törzs & $\begin{array}{c}\text { FumonizinB } \\
(\boldsymbol{\mu g} / \mathbf{k g})\end{array}$ & $\begin{array}{c}\text { OTA } \\
(\boldsymbol{\mu g} / \mathbf{k g})\end{array}$ \\
\hline J2a & - & - \\
J2c & 378,3 & - \\
M1b & 77 & - \\
M3b & 5478,5 & 20,44 \\
M4a & - & 281,845 \\
M5a & - & - \\
M5b & - & - \\
P1a & - & - \\
P1b & - & - \\
P1c & - & - \\
P2a & - & - \\
S1b & - & 39,584 \\
S1c & - & 28,31 \\
S2b & - & - \\
S2c & - & - \\
Sp1a & - & - \\
Sp2a & 1145,7 & - \\
\hline
\end{tabular}

\section{Hagymaminták fumonizin-szennyezettsége}

A hagymaminták fumonizintartalmát RP-HPLC/ESI-ITMS-technikával mértük. Fumonizineket két hagymamintában detektáltunk, ezekben kis mennyiségben $(0,32$ és 0,33 $\mathrm{mg} / \mathrm{kg}$ ) $\mathrm{FB}_{2}, \mathrm{FB}_{3}, \mathrm{FB}_{4}, 3$-epi-FB 4 , izo-FB ${ }_{1}$ izomereket mutattunk ki (13. táblázat, 16. ábra).

13. táblázat: Hagymaminták fumonizintartalma

\begin{tabular}{cccccccc}
\hline \multirow{2}{*}{ Minta } & \multicolumn{7}{c}{ Detektált fumonizin-izomerek mennyisége $(\boldsymbol{\mu g} / \mathbf{k g})$} \\
\cline { 2 - 8 } & \multirow{2}{*}{$\mathrm{FB}_{2}$} & $\mathrm{FB}_{3}$ & $\mathrm{FB}_{4}$ & 3 -epi-FB 4 & izo-FB & izo- & Összes FB \\
\hline $\mathrm{A}$ & 203,75 & 9,50 & 48,46 & 58,58 & 6,21 & 16,14 & 324,64 \\
$\mathrm{C}$ & 16,73 & 25,06 & 288,22 & - & - & - & 330,01 \\
\hline
\end{tabular}




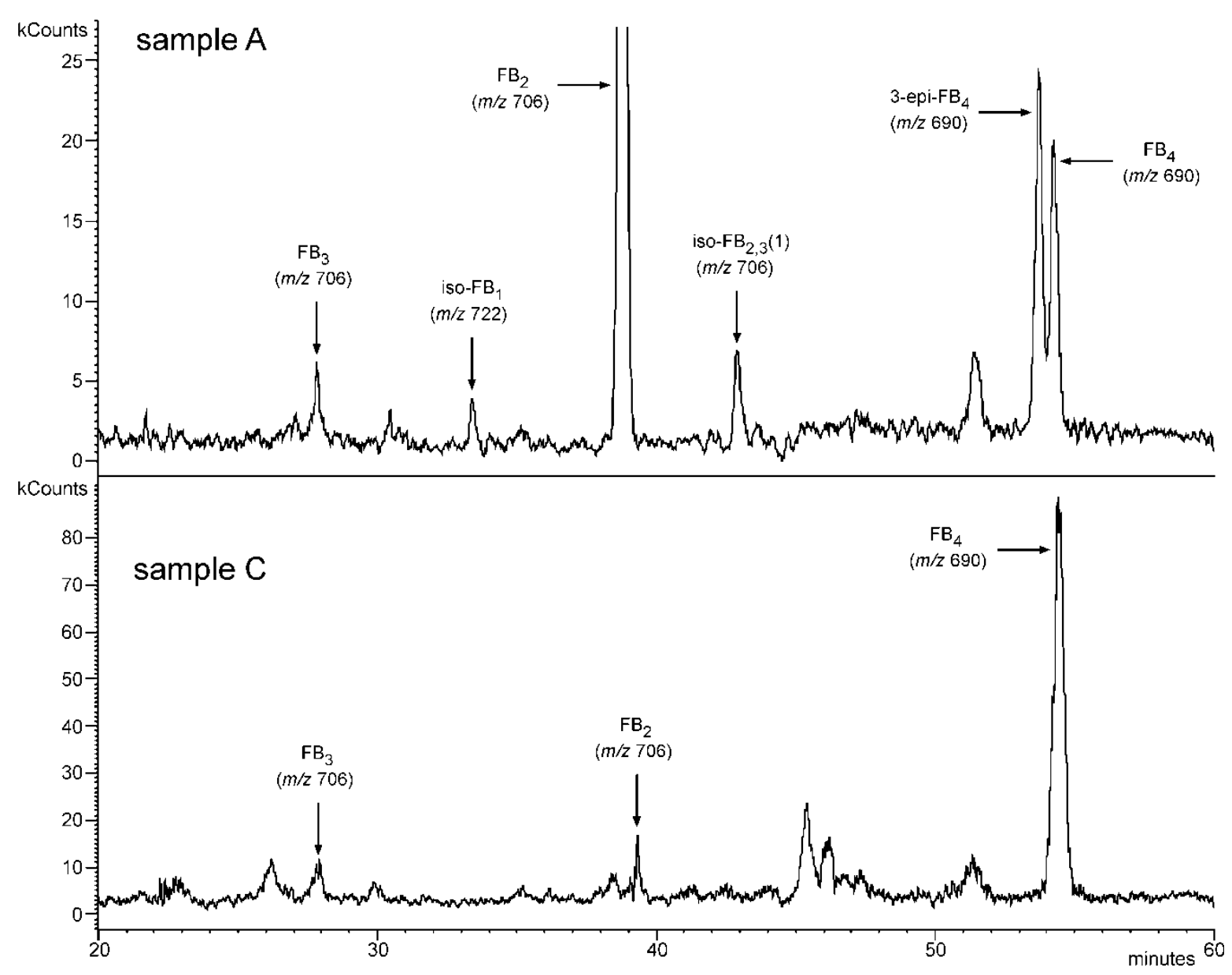

16. ábra. Az „A ” és „C ” hagymamintákban kimutatott fumonizin-izomerek

A hagymanövényt, a benne található alliin és egyéb antimikrobiális vegyületek miatt csak kevés penészgomba képes kolonizálni, következésképpen mikotoxinok jelenlétére is kicsi az esély. Filtenborg és munkatársai (1996) hagymaminták OTA-tartalmát vizsgálták, de nem találtak kimutatható mennyiségü mikotoxint. Frank (1977) munkája során mesterségesen fertőzött meg hagymamintákat patulintermelő Penicillium expansum, P. urticae és Byssochlamys nivea törzsekkel, de ennek ellenére sem tapasztalt patulin-szennyezettséget a vizsgált mintákban. Az A. niger által termelt malformin másodlagos metabolitot már kimutatták hagymaminták külső leveléből (Curtis és mtsai. 1974). Seefelder és munkatársai (2002) F. proliferatum-mal fertőzött fokhagymában detektáltak fumonizin $\mathrm{B}_{1}$-et. Az eddigi irodalmi adatok alapján vöröshagymában fumonizint még nem mutattak ki. Frisvad és munkatársai (2007) azt tapasztalták, hogy a fumonizinek termelésére képes fekete Aspergillus-ok (A. niger és A. welwitschiae) a kis vízaktivitású, magas só-, vagy cukortartalmú tápközegekben termelnek elsősorban fumonizineket, ezért feltételezhető, hogy - a száraz külső leveleket leszámítva - nagy víztartalmú hagymanövény nem segíti elő a fekete Aspergillus törzsek fumonizin-termelését. 


\section{Összefoglalás}

Az Aspergillus nemzetség a fonalasgombák egy nagyon változatos csoportját foglalja magába, mely gazdaságilag is nagy jelentőséggel rendelkezik. Az egész Aspergillus nemzetségre vonatkozóan elmondható, hogy az egymással közeli rokonságban álló fajok morfológiai alapon történő elkülönítése igen nehéz, néhány esetben nem is lehetséges. Erre a célra a genomi szekvenciák (pl. a kalmodulin és $\beta$-tubulin gének szekvenciái) alapján történő fajelkülönítés sokkal jobban alkalmazható. Számos tanulmány született már az Aspergillus nemzetség filogenetikai kapcsolatainak feltérképezése érdekében, azonban az eddigi munkák általában valamelyik alcsoportra (szekcióra, alnemzetségre) fókuszálnak, nemzetség szintü áttekintásre kevés példát találunk (Samson és mtsai. 2014).

A fekete Aspergillus-oknak a nemzetség Nigri szekciójában elhelyezkedő fajokat nevezzük, az ide tartozó legismertebb faj az A. niger (Gams és mtsai. 1985). Ismertségét annak köszönheti, hogy igen széles körben elterjedt a biotechnológiai alkalmazása. Elsősorban citromsav, glükonsav ipari mértékü előállítására használják, de emellett számos enzim, pl.: pektináz, amiláz gazdaságos előállítása is lehetséges általuk (Varga és mtsai. 2000). Hasznos tulajdonságaik ellenére károkat is okozhatnak, mert humán megbetegedéseket válthatnak ki, valamint egyes fajok mikotoxinok előállítására is képesek, melyek előfordulhatnak élelmiszereinkben, és elfogyasztásuk hosszú távon káros hatást fejt ki egészségünkre. Az egyik ilyen mikotoxin-csoport a fumonizinek csoportja. Ezek karcinogén mikotoxinok, melyek számos betegséggel hozhatók összefüggésbe mind emberek, mind állatok esetén.

Fekete Aspergillus-ok különböző megbetegedések okozói lehetnek. Opportunista patogének lévén, olyan esetekben okoz fertőzést, amelyekben az immunrendszer valamilyen okból nem megfelelően működik. A modern immunoszupresszáns terápiák napjainkban egyre elterjedtebbé válnak, ezért az ilyen jellegü fertőzéseknek a száma és jelentősége egyre növekszik (Cohen és mtsai. 1993). A fekete Aspergillus-ok elsősorban a légzőszervrendszerben szaporodnak el, de szemfertőzést (keratitisz) és fülfertőzést (otitisz) is okozhatnak. A légzőszervrendszerben jelentkező fertőzés sok esetben halálos kimenetelü lehet, ezért ezekben az esetekben nagyon fontos, hogy a lehető leghatékonyabb terápiát lehessen alkalmazni, és ezzel csökkenteni a gomba szaporodásának lehetőségét. Ehhez elengedhetetle, hogy pontosan tudjuk, melyik faj okozta a megbetegedést, mert a különböző fajok eltérő mértékben lehetnek érzékenyek antifungális szerekkel szemben (Balajee és mtsai. 2005). Az eddigi gyakorlat azt mutatja, hogy a klinikai fekete Aspergillus izolátumokat általában A. niger-ként azonosítják 
morfológiai alapon, azonban több olyan, egymással közeli rokonságban álló fekete Aspergillus faj is okozhatnak humán fertőzéseket, amelyek morfológiai karakterek alapján nem különíthetőek el egymástól.

Munkám főbb eredményeit az alábbiakban foglalom össze:

\section{Az Aspergillus nemzetség filogenetikai analízise.}

A teljes Aspergillus nemzetséget reprezentatívan mintázó filogenetikai vizsgálatot végeztünk 93 faj bevonásával. Az elemzés során 6 génszakaszt szaporítottunk fel, majd bázissorrendjüket meghatároztuk. A felszaporított génszakaszok a következők voltak: RPB1, RPB2 (RNS polimeráz II alegységei), Tsr1 (20S rRNS összeszerelésében szerepet játszó fehérje), illetve a Cct8 (dajkafehérje), Acl1 (ATP citrát-liáz) és MCM7 (minikromoszómák fenntartásáért felelős). A filogenetikai analízist Maximum Likelihood és MrBayes módszerekkel végeztük el. Eredményeink alapján az Aspergillus nemzetség 6 alnemzetségre és 23 szekcióra bontható. Az Aspergillus (bootstrap-érték: 100 / poszterior valószínüség: 1), Polypaecili (100/1), Cremei (90/1), Fumigati (100/1) és Nidulantes (100/1) alnemzetségek magas támogatottsági értékekkel rendelkeznek, a Circumdati (47/1) alnemzetség támogatottsága kisebb a ML-analízis alapján. A nemzetségen belül a ML-analízis alapján az Usti és Restricti szekciók kivételével minden szekció monofiletikusnak bizonyult közepes, vagy magas támogatottsági értékek mellett. Mind a ML, mind a MrBayes analízis alapján az Usti szekció két csoportra különült, ahol az A. amylovorus, A. subsessilis és A. egyptiacus fajok egy jól elhatárolódó kládot alkotnak magas támogatottsági értékek mellett (92/1). A Restricti szekció képviselői nem alkotnak elkülönülő kládot. A Polypaecilum és Phialosimplex nemzetségekbe tartozó gombák az Aspergillus nemzetség Cremei és Aspergillus szekciójába tartozó fajokkal mutatnak rokonságot, ennek következtében ezeket a fajokat az Aspergillus nemzetség tagjainak tekintjük, ami a nevezéktanban is ennek megfelelő változást von maga után. Így a korábban Phialosimplex caninus, Phialosimplex clamydosporus, Phialosimplex sclerotiales, Polypaecilum insolitum, Polypaecilum pisci neveket viselö fajok az Aspergillus nemzetségnevet kapták. A Penicillium inflatum faj az Aspergillus nemzetségbe sorolható, ezért az Aspergillus inflatus nevet kapta. Az általunk tapasztalt eredmények szerint a Versicolores, Nidulantes, Aenei, Raperi, Usti, Bispori, Ochraceorosei és Sparsi szekciók egy nagy csoportot alkotnak, melyen belül a Nidulantes és Versicolores szekciók ugyan elkülönülnek egymástól, de nem szekciószinten. Eredményeink alapján a Nigri szekció nem a Flavi, hanem a Terrei, Flavipedes, Jani és Candidi szekciókkal alkot testvércsoportot. A Flavi szekció testvérkládja a 
Circumdati szekció, a Cremei szekció pedig a távoli Polypaecili, Restricti és Aspergillus szekciókkal mutat rokonságot. A korábban a Sparsi szekcióba sorolt A. funiculosus az A. ochraceorosei-vel mutat rokonságot, így inkább tekinthető az Ochraceorosei szekció tagjának.

\section{Az A. niger és $A$. welwitschiae törzsek genetikai variabilitásának vizsgálata.}

Két nagyon közeli csoport, az A. niger és A. welwitschiae törzsek izolátumainak genetikai variabilitását UP-PCR módszerrel vizsgáltuk. A 88 fragment figyelembe vételével készített binomiális mátrix alapján létrehozott Neighbour-joining fán az izolátumok két egyértelműen elkülönülő csoportot alkotnak, így elmondhatjuk, hogy az A. niger és $A$. welwitschiae izolátumok UP-PCR módszerrel elkülöníthetőek egymástól.

\section{Fülfertőzésekből származó fekete Aspergillus izolátumok azonosítása, érzékenységük} antifungális szerekkel szemben.

Munkánk során 7 iráni ás 14 magyarországi fülfertőzésből származó izolátumot vizsgáltunk, melyeket kivétel nélkül $A$. niger-ként azonosítottak a hagyományos, morfológián alapuló módszerrel. A kalmodulin gén egy szakaszának szekvenciái alapján elvégeztük az izolátumok fajszintü besorolását. Eredményeink alapján az A. niger-en kívül más fekete Aspergillus fajok (A. welwitschiae és A. tubingensis) is okozhatnak fülfertőzéseket. $\mathrm{Az}$ izolátumok érzékenységét a klinikumban széles körben használt gombaellenes szerekkel (flukonazol, itrakonazol, ketokonazol, terbinafin, amfotericin B) szemben vizsgálatuk. A

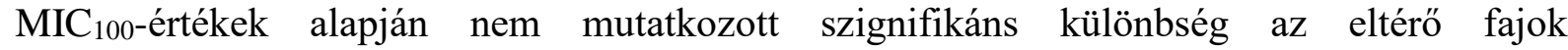
érzékenységében, de elmondhatjuk, hogy a terbinafin ( $\mathrm{MIC}_{100}: 0,25-1 \mu \mathrm{g} / \mathrm{ml}$ ) és itrakonazol ( $\mathrm{MIC}_{100}: 0,5-1 \mu \mathrm{g} / \mathrm{ml}$ ) hatásosabbnak bizonyultak, mint a ketokonazol ( $\mathrm{MIC}_{100}: 8-16 \mu \mathrm{g} / \mathrm{ml}$ ). Az amfotericin B-vel szemben a magyarországi izolátumok érzékenyebbek, mint az iráni izolátumok, ennek okát nem ismerjük.

\section{Fekete Aspergillus izolátumok előfordulása élelmiszereken, a törzsek fuminizin-} termelésének és az adott élelmiszerek fuminizin-tartalmának vizsgálata

Fekete Aspergillus izolátumokat gyüjtöttünk mazsola-, datolya-, füge- és hagymamintákról, majd részleges kalmodulin génszekvenciáik alapján fajszinten azonosítottuk öket. A mazsolamintákról származó izolátumok közül 16 A. welwitschiae-nek, 16 pedig A. niger-nek bizonyult. Az izolátumok 66\%-a termelt fumonizineket átlagosan $5 \mathrm{mg} / \mathrm{kg}$ mennyiségben, két izolátum azonban kiugróan nagy, 15 és $17 \mathrm{mg} / \mathrm{kg}$ koncentrációban termelte 
ezeket a mikotoxinokat. A mazsolaminták fumonizintartalmát vizsgálva megállapítottuk, hogy a minták átlagosan $7 \mathrm{mg} / \mathrm{kg}$ koncentrációban voltak szennyezettek, azonban egy minta esetében kiugróan magas, $35 \mathrm{mg} / \mathrm{kg}$ koncentrációt tapasztaltunk. Összehasonlításképpen megemlítendő, hogy az Európai Unió által a fumonizin-szennyezettséget illetően az elfogadott legmagasabb határérték $4 \mathrm{mg} / \mathrm{kg}$, ami feldolgozatlan kukoricára vonatkozik. Datolyamintákról 35 fekete Aspergillus törzset izoláltunk, a szekvenciaadatok alapján ezek mindegyike az A. tubingensis fajba tartozott, mely mikotoxinok termelésére nem képes. A fügéről származó izolátumok többsége is az A. tubingensis fajba tartozott, kivéve 6 izolátumot, melyek az A. niger fajba sorolhatóak. A fügeminták közül egy Iránból származó mintában tudtunk fumonizineket kimutatni: $\mathrm{FB}_{1}, \mathrm{FB}_{2}, \mathrm{FB}_{3}$ és $\mathrm{FB}_{4}$ izomereket detektáltunk, $0,16 \mathrm{mg} \mathrm{kg}^{-1}$ összmennyiségben. Hagymáról 35 fekete Aspergillus törzset izoláltunk, mind a külső száraz, mind a belső húsos levelekből. Részleges kalmodulin génszekvenciáik alapján az összes izolátum az A. niger-rel nagyon közeli rokonságban álló A. welwitschiae fajba sorolható. Vizsgáltuk az izolátumok mikotoxintermelő képességét, mely alapján 15\%-ukat találtuk képesnek fumonizinek, 17\%ukat pedig ochratoxin A termelésére. A vizsgált 5 hagymaminta esetében két mintában találtunk fumonizin-izomereket 0,32 és $0,33 \mathrm{mg} \mathrm{kg}^{-1}$ mennyiségben. A fumonizin-izomerek között a $\mathrm{FB}_{2}$ 4, 3-epi-FB 4 , izo-FB $1\left(\mathrm{FB}_{6}\right)$ és izo- $\mathrm{FB}_{2,3}$ formákat azonosítottuk. 


\section{Summary}

Aspergillus is a diverse genus with high economic and social impact. Several closely related species cannot be reliably distinguished on the basis of morphological criteria alone. Molecular tools have been developed to solve this issue, with sequence-based methods being the most valuable for species delimitation. Partial sequences of the calmodulin or $\beta$-tubulin genes are suitable to discriminate species within the genus Aspergillus. Aspergillus has been the subject of a large number of taxonomic studies using DNA sequence data. Many of these studies focused on specific groups (species, sections, subgenera) within Aspergillus and the number of phylogenetic studies at the genus level and above are limited (Samson et al. 2014). The black aspergilli (Aspergillus section Nigri) is an important group of species in food mycology, medical mycology and biotechnology. A. niger is used in the fermentation industry to produce hydrolytic enzymes, such as amylases or lipases, and organic acids, such as citric acid and gluconic acid (Varga et al. 2000). Besides their economic importance, black aspergilli are also important as opportunistic human pathogens and many species cause food spoilage and are potential producers of mycotoxins (fumonisins, ochratoxin A) which contaminate several agricultural products.

Black aspergilli are opportunistic human pathogens, but the importance of these diseases is growing with the spreading of immunosuppressive therapy (Cohen et al. 1993). The disease usually occurs in the respiratory system, but they can also cause keratitis and otitis. In order to select the appropriate treatment, the correct identification of these clinical isolates is essential, as not all species have the same susceptibility patterns against several antifungal drugs (Balajee et al. 2005). Clinical black Aspergilli are usually identified as A. niger using conventional morphological methods. However, recent molecular analyses showed that, apart from A. niger other black Aspergilli are also important as potential opportunistic pathogens in human infections (Munguia and Daniel 2008).

The objectives of the present study were:

- Production of a robustm genus-wide phylogeny to get insight into the evolutionary relationships of this economically important genus.

- Analysis of the genetic variability of the two closely related black Aspergillus species A. niger and A. welwitschiae.

- Identification of black Aspergillus isolates from otomycosis cases, and investigation of their susceptibility against several antifungal drugs. 
- Identification of black Aspergillus isolates from food samples, and analysis of their fumonisin producing ability and the fumonisin content of the investigated food samples.

Our main results were the following:

\section{Phylogenetic analysis of the genus Aspergillus}

Ninety-three species had been involved in the analysis, which represent the genus properly. The Acl1 (ATP citrate lyase), MCM7 (mini-chromosome maintenance complex component 7), RPB1, RPB2 (RNA Polymerase II largest and second largest subunit), Tsr1 (ribosome maturation factor) and $\operatorname{Cct} 8$ (chaperonin containing TCP1 subunit) genes were amplified and sequenced. Combined sequence data were created and the phylogenetic analysis was carried out by Maximum Likelihood and MrBayes methods. According to our data the genus Aspergillus can be divided into 6 subgenera and 22 sections. The Aspergillus (bootstrap value: 100/ posterior probability: 1), Polypaecili (100/1), Cremei (90/1), Fumigati (97/1) and Nidulantes (100/1) subgenera have high support values, however the subgenus Circumdati has lower bootstrap value (47/1). Except Usti, all the sections are monophyletic according to the ML analysis with moderate or high bootstrap values. The section Usti is divided into two groups, and A. amylovorus and A. egypticus represent a separate clade with high support values (92/1). Fungi belonging to Polypaecilum and Phialosimplex seem to be in relation with members of sections Cremei and Aspergillus, thus the former Phialosimplex caninus, Phialosimplex clamydosporus, Phialosimplex sclerotiales, Polypaecilum insolitum and Polypaecilum pisci species get the genus name Aspergillus. Penicillium inflatum is related to genus Aspergillus, consequently this species is transferred to genus Aspergillus under the name A. inflatus. According to our data, sections Versicolores, Nidulantes, Aenei, Raperi, Usti, Bispori, Ochraceorosei and Sparsi belong to one group. Species of Versicolores and Nidulantes are divided, but not at the section level. Section Nigri is the sister group of Candidi and Terrei, not Flavi. The sister group of Flavi is section Circumdati. Section Cremei is related to sections Polypaecili, Restricti and Aspergillus. A. funiculosus has been classified to section Sparsi, but this speies is related to A. ochraceoroseus, thus belongs to section Ochraceorosei.

\section{Intvestigation of the genetic variability of two closely related black Aspergillus species,}

\section{A. niger and A. welwitschiae}

The genetic variability of $A$. niger and $A$. welwitschiae was studied by the UP-PCR method. A Neighbour-joining tree was generated based on a binomial matrix which contains 
the data of 88 fragments. On this tree the two species appear in separated clades, thus these closely related species can be distinguished from each other with this method.

\section{Identification of black Aspergillus isolates from otomycosis cases, and their susceptibility to different antifungal drugs}

Seven samples from Iran and 14 samples from Hungary were investigated. According to the clinical implication, all of them were identified as A. niger on the basis of conventional morphological methods. However, based on sequence analysis of a part of the calmodulin gene, our data showed that apart from A. niger, other Aspergillus species (A. welwitschiae and A. tubingensis) can also cause otomycosis. The susceptibilities of the isolates to commonly used antifungal agents (amphotericin B, itraconazole, fluconazole, ketoconazole and terbinafine) were tested in vitro. Based on the $\mathrm{MIC}_{100}$ values there were no significant differences among the susceptibilities of the different species. Terbinafine (MIC $\left.{ }_{100}: 0.25-1 \mu \mathrm{g} / \mathrm{ml}\right)$ and itraconazole ( $\mathrm{MIC}_{100}: 0.5-1 \mu \mathrm{g} / \mathrm{ml}$ ) were more effective than ketoconazole ( $\mathrm{MIC}_{100}: 8-16 \mu \mathrm{g} / \mathrm{ml}$ ). Amphotericin B was more effective against the isolates from Hungary, than against the isolates from Iran.

\section{Presence of black Aspergilli on food samples and their ability to produce fumonisins,} fumonisin content of food samples contaminated by black Aspergillus strains.

Black Aspergillus strains were isolated from raisin, date, fig and onion samples. The isolates were identified based on partial calmodulin gene sequences. Among 32 black Aspergillus isolates from raisins, 16 were found to belong to A. niger and 16 to A. welwitschiae. Sixty-six $\%$ of the isolates were found to be able to produce fumonisins. Several isomers of fumonisins were identified in the extracts of the isolates. The average production of fumonisins by the toxinogenic species was around $5 \mathrm{mg} / \mathrm{kg}$, but two of the isolates produced fumonisins in a very high concentration (15 and $17 \mathrm{mg} / \mathrm{kg}$, respectively). The average fumonisin content of the raisin samples was around $7 \mathrm{mg} / \mathrm{kg}$, but in the case of one sample we could detect $35 \mathrm{mg} / \mathrm{kg}$ (for comparison, the EU limit for unprocessed maize is $4 \mathrm{mg} / \mathrm{kg}$ ). Regulations do not exist for the fumonisin content of raisins.

All of the 35 black Aspergillus strains isolated from dates were found to belong to $A$. tubingensis based on calmodulin sequence data. This species is not able to produce mycotoxins. 
The majority of the isolates originated from figs were also belonging to A. tubingensis, but $6 \mathrm{~A}$. niger isolates were also detected. One fig sample was contaminated by fumonisins at a low concentration $(0.16 \mathrm{mg} / \mathrm{kg})$.

All of the 35 black Aspergillus strains isolated from onion samples were found to belong to A. welwitschiae based on calmodulin sequence data. Fifteen $\%$ of the isolates were able to produce fumonisins, while $17 \%$ produced ochratoxin A. Two of the onion samples were contaminated by fumonisins at low concentrations $(0.32$ and $0.33 \mathrm{mg} / \mathrm{kg})$. 


\section{Irodalomjegyzék}

Accensi, F., Cano, J., Figuera, L., Abarca, M. L., Cabañes, F. J. 1999. New PCR methods to differentiate species in the Aspergillus niger aggregate. FEMS Microbiol. Lett. 180: 191-196.

Aktas, E., Yigit, N. 2009. Determination of antifungal susceptibility of Aspergillus spp. responsible for otomycosis by E-test method. J. Mycol. Med. 19: 122-125.

Alcazar-Fuoli, L., Mellado, E., Alastruey-Izquierdo, A., Cuenca-Estrella, M., RodriguezTudela, J. L. 2009. Species identification and antifungal susceptibility patterns of species belonging to Aspergillus section Nigri. Antimicrob. Agents Chemother. 53: 4514-4517.

Al-Musallam, A. 1980. Revision of the black Aspergillus species. Thesis, Utrecht University, Centraalbureau voor Schimmelcultures, Baarn.

Altschul, S. F., Gish, W., Miller, W., Myers, E. W., Lipman, D. J. 1990. Basic Local Alignment Search Tool. J. Mol. Biol. 215: 403-410.

Baker, S. E. 2006. Aspergillus niger genomics: past, present and into the future. Med. Mycol. 44: 17-21.

Balajee, S. A., Gribskov, J., Brandt, M., Ito, J., Fothergill, A., Marr, K. A. 2005. Mistaken identity: Neosartorya pseudofischeri and its anamorph masquerading as Aspergillus fumigatus. J. Clin. Microbiol. 43: 5996-5999.

Balajee, S. A., Kano, R., Baddley, J. W., Moser, S. A., Marr, K. A., Alexander, B. D., Andes, D., Kontoyiannis, D. P., Perrone, G., Peterson, S., Brandt, M. E., Pappas, P. G., Chiller, T. 2009. Molecular identification of Aspergillus species: Transplant Associated Infection Surveillance Network (TRANSNET). J. Clin. Microbiol. 47: 3138-3141.

Bartók, T., Szécsi, Á., Szekeres, A., Mesterházy, Á., Bartók, M. 2006. Detection of new fumonisin mycotoxins and fumonisin-like compounds by reversed-phase high-performance liquid chromatography / electrospray ionization ion trap mass spectrometry. Rapid Commun. Mass Spectrom. 20: 2447-2462. 
Bartók, T., Tölgyesi, L., Szekeres, A., Varga, M., Bartha, R., Szécsi, Á., Bartók, M., Mesterházy, Á. 2010. Detection and characterization of twenty-eight isomers of fumonisin $\mathrm{B}_{1}$ $\left(\mathrm{FB}_{1}\right)$ mycotoxin in a solid rice culture infected with Fusarium verticillioides by reversed-phase high-performance liquid chromatography / electrospray ionization time-of-flight and ion trap mass spectrometry. Rapid Commun. Mass Spectrom. 24: 35-42.

Bendele, A. M., Neal, S. B., Oberly, T. J., Thompson, C. Z., Bewsey, B. J., Hill, L. E., Rexroat, M. A., Carlton, W. W., Probst, G. S. 1985. Evaluation of ochratoxin A for mutagenicity in a battery of bacterial and mammalian cell assays. Food Chem. Toxicol. 23: 911-918.

Berbee, M. L., Yoshimura, A., Sugiyama, J., Taylor, J. W. 1995. Is Penicillium monophyletic - an evaluation of phylogeny in the family Trichocomaceae from 18S, 5.8S and ITS ribosomal DNA-sequence data. Mycologia 87: 210-222.

Bezuidenhout, S. C., Gelderblom, W. C. A., Gorst-Allman, C. P., Horak, R. M., Marasas, W. F. O., Spiteller, G., Vleggaar, R. 1988. Structure elucidation of the fumonisins, mycotoxins from Fusarium moniliforme. J. Chem. Soc., Chem. Commun. 743-745.

Bonifaz, A., Chavolla-Magana, R., Araiza, J. 2010. Aspergillus otitis. In: Pasqualotto, A. C. (szerk.) Aspergillosis: from diagnosis to prevention. pp. 999-1006. Springer, Dordrecht.

Boorman, G. A., Mcdonald, M. R., Imoto, S., Persing, R. 1992. Renal lesions induced by ochratoxin A exposure in the F344 rat. Toxicol. Pathol. 20: 236-247.

Bouhet, S., Le Dorze, E., Peres, S., Fairbrother, J. M., Oswald, I. P. 2006. Mycotoxin fumonisin B1 selectively down-regulates the basal IL-8 expression in pig intestine: in vivo and in vitro studies. Food Chem. Toxicol. 44: 1768-1773.

Brown, D. W., Cheung, F., Proctor, R. H., Butchko, R. A., Zheng, L., Lee, Y., Utterback, T., Smith, S., Feldblyum, T., Glenn, A. E., Plattner, R. D., Kendra, D. F., Town, C. D., Whitelaw, C. A. 2005. Comparative analysis of 87.000 expressed sequence tags from the fumonisinproducing fungus Fusarium verticillioides. Fungal Genet. Biol. 42: 848-861.

Bulat, S. A., Lübeck, M., Alekhina, I. A., Jensen, D. F., Knudsen, I. M. B. and Lübeck, P. S. 2000. Identification of a universally primed-PCR-derived sequence characterized amplified region marker for an antagonistic strain of Clonostachys rosea and development of a strainspecific PCR detection assay. Appl. Environ. Microbiol. 66: 4758-4763. 
Bulat, S. A., Mironenko, N. V., Lapteva, M. N., Strelchenko, P. P. 1994. Polymerase chain reaction with universal primers (UP-PCR) and its application to plant genome analysis. In: Adams, R. P., Miller, J. S., Goldenberg, E. M., Adams, J. E. (szerk.) Conservation of plant genes II. 8. Utilization of ancient and modern DNA. St. Louis: Missouri Botanical Garden pp. 113-129.

Chamilos, G., Lewis, R. E., Albert, N., Kontoyiannis, D. P. 2007. Paradoxical effect of echinocandins across Candida species in vitro: evidence for echinocandin-specific and Candida species-related differences. Antimicrob. Agents Chemother. 51: 2257-2259.

Chen, A. J., Frisvad, J. C., Sun, B. D., Varga, J., Kocsubé, S., Dijksterhuis, J., Kim, D. H, Hong, S. B., Houbraken, J., Samson, R. A. 2016. Aspergillus section Nidulantes (formerly Emericella): Polyphasic taxonomy, chemistry and biology. Stud. Mycol. 84: 1-118.

Cohen, J., Denning, D. W., Viviani, M. A. 1993. Epidemiology of invasive aspergillosis in European cancer centres. EORTC Invasive Fungal Infections Cooperative Group. Eur J Clin Microbiol Infect Dis. 12: 392-393.

Curtis, R.W., Stevenson, W.R., and Tuit, J. 1974. Malformin in Aspergillus niger infected onion bulbs (Allium cepa). Appl. Microbiol. 28: 362-365.

de Vries, R. P., Riley, R., Wiebenga, A., Aguilar-Osorio, G., Amillis, S., Uchima, C. A., Anderluh, G., Asadollahi, M., Askin, M., Barry, K., Battaglia, E., Bayram, Ö., Benocci, T., Braus-Stromáeyer, S. A., Caldana, C., Cánovas, D., Cerqueira, G. C., Chen, F., Chen, W., Choi, C., Clum, A., Corrêa dos Santos, R. A., de Lima Damásio, A. R., Diallinas, G., Emri, T., Fekete, E., Flipphi, M., Freyberg, S., Gallo, A., Gournas, C., Habgood, R., Hainaut, M., Harispe, M. L., Henrissat, B., Hildén, K. S., Hope, R., Hossain, A., Karabika, E., Karaffa, L., Karányi, Zs., Kraševec, N., Kuo, A., Kusch, H., LaButti, K., Lagendijk, E. L., Lapidus, A., Levasseur, A., Lindquist, E., Lipzen, A., Logrieco, A. F., MacCabe, A., Mäkelä, M. R., Malavazi, I., Melin, P., Meyer, V., Mielnichuk, N., Miskei, M., Molnár, Á. P., Mulé, G., Ngan, C. Y., Orejas, M., Orosz, E., Ouedraogo, J. P., Overkamp, K. M., Park, H. S., Perrone, G., Piumi, F., Punt, P. J., Ram, A. F. J., Ramón, A., Rauscher, S., Record, E., Riaño-Pachón, D. M., Robert, V., Röhrig, J., Ruller, R., Salamov, A., Salih, N. S., Samson, R. A., Sándor, E., Sanguinetti, M., Schütze, T., Sepčić, K., Shelest, E., Sherlock, G., Sophianopoulou, V., Squina, F. M., Sun, H., Susca, A., Todd, R. B., Tsang, A., Unkles, S. E., van de Wiele, N., van Rossen-Uffink, D., Velasco de Castro Oliveira, J., Vesth, T. C., Visser, J., Yu, J. H., Zhou, M., Andersen, M. R., Archer, D. B., Baker, S. E., Benoit, I., Brakhage, A. A., Braus, G. H., Fischer, R., Frisvad, J. C., Goldman, G. H., Houbraken, J., Oakley, B., Pócsi, I., Scazzocchio, C., Seiboth, B., vanKuyk, P. A., Wortman, J., Dyer P. S., Grigoriev, I. V. 2017. Comparative genomics reveals high biological diversity and specific adaptations in the industrially and medically important fungal genus Aspergillus. Genome Biol. 18: 28. 
Fasunla, J., Ibekwe, T., Onakoya, P. 2007. Otomycosis in western Nigeria. Mycoses. 51: 67-70.

Felsenstein, J. 2007. PHYLIP (Phylogeny Inference Package). Version 3.67 Distributed by the author. Department of Genome Sciences and Department of Biology University of Washington, Seattle.

Filtenborg, O., Frisvad, J. C., Thrane, U. 1996. Moulds in food spoilage. Int. J. Food Microbiol. 33: $85-102$.

Frank, H. K. 1977. Occurrence of patulin in fruit and vegetables. Ann. Nutr. Aliment. 31: 459465.

Fries, E. M. 1832. Sistema Mycologicum. Moritz, Gryphiswald

Frisvad, J. C., Samson, R. A. 2000. Neopetromyces gen. nov. and an overview of teleomorphs of Aspergillus subgenus Circumdati. Stud. Mycol. 45: 201-208.

Frisvad, J. C., Samson, R. A. 2004. Polyphasic taxonomy of Penicillium subgenus Penicillium. A guide to identification of food and air-borne terverticillate Penicillia and their mycotoxins. Stud. Mycol. 49: 1-173.

Frisvad, J. C., Smedsgaard, J., Samson, R. A., Larsen, T. O., Thrane, U. 2007. Fumonisin B2 production by Aspergillus niger. J. Agric. Food Chem. 55: 9727-9732.

Gams, W., Christensen, M., Onions, A. H., Pitt, J. I., Samson, R. A. 1985. Infrageneric taxa of Aspergillus. In: Samson, R. A., Pitt, J. I. (szerk.) Advances in Penicillium and Aspergillus Systematics. pp. 55-62. Plenum Press, New York.

Geiser, D. M., Samson, R. A., Varga, J. 2008. A review of molecular phylogenetics in Aspergillus and prospects for a robust genus-wide phylogeny. In: Varga, J., Samson, R. A. (szerk.) Aspergillus in the genomic era. pp. 17-32. Academic Publishers, Wageningen.

Gelderblom, W. C. A., Jaskiewicz, K., Marasas, W. F. O., Thiel, P. G., Horak, R., M., Vleggaar, R., Kriek, N. P. J. 1988. Fumonisins - Novel mycotoxins with cancer-promoting activity produced by Fusarium moniliforme. Appl. Environt. Microbiol. 54: 1806-1811. 
Gelderblom, W. C. A., Sewram, V., Shephard, G.S., Snijman, P.W., Tenza, K., van der Westhuizen, L., Vleggaar, R. 2007. Structure and natural occurrence of stereoisomers of the fumonisin B series mycotoxins. J. Agricult. Food Chem. 55: 4388-4394.

Gherbawy, Y., Elhariry, H., Kocsubé, S., Bahobial, A., Deeb, B. E., Altalhi, A., Varga, J., Vágvölgyi, Cs. 2015. Molecular characterization of black Aspergillus species from onion and their potential for Ochratoxin A and Fumonisin B2 production. Foodborne Pathog. Dis. 12: 414-423.

Hamari, Z., Kevei, F., Kovács, E., Varga, J., Kozakiewicz, Z., Croft, J. H. 1997. Molecular and phenotypic characterization of Aspergillus japonicus and Aspergillus aculeatus strains with special regard to their mitochondrial DNA polymorphisms. Anton. Leeuw. Int. J. G. 72: 337347.

Haschek, W. M., Gumprecht, L. A., Smith, G., Tumbleson, M. E., Constable, P. D. 2001. Fumonisin toxicosis in swine: an overview of porcine pulmonary oedema and current perspectives. Environ. Health Perspect. 109: 251-257.

Hillis, D.M., Bull, J. J. 1993. An empirical test of bootstrapping as a method for assessing confidence in phylogenetic analysis. Syst. Biol. 42: 182-192.

Hogan, L. H., Klein, B. S., Levitz, S. M. 1996. Virulence factors of medically important fungi. Clin. Microbiol. Rev. 9: 469-488.

Hong, S. B., Cho, H. S., Shin, H. D., Frisvad, J. C., Samson, R. A. 2006. Novel Neosartorya species isolated from soil in Korea. Int. J. Syst. Evol. Microbiol. 56: 477-486.

Hong, S. B., Lee, M., Kim, D. H., Varga, J., Frisvad, J. C., Perrone, G., Gomi, K., Yamada, O., Machida, M., Houbraken, J., Samson, R A. 2013. Aspergillus luchuensis, an industrially important black Aspergillus in East Asia. PLOS One 8: 1-9.

Houbraken, J., Samson, R. A. 2011. Phylogeny of Penicillium and the segregation of Trichocomaceae into three families. Stud. Mycol. 70: 1-51.

Houbraken, J., Vries, R. P., Samson, R. A. 2014. Modern taxonomy of biotechnologically important Aspergillus and Penicillium species. Adv. Appl. Microbiol. 86: 199-249. 
Howard, S. J., Harrison, E., Bowyer, P., Varga, J., Denning, D. W. 2011. Cryptic species and azole resistance in the Aspergillus niger complex. Antimicrob. Agents Chemother. 55: 48024809.

Hubka, V, Nováková, A., Kolarík, A., Jurjevic, Z., Peterson, S. W. 2015. Revision of Aspergillus section Flavipedes: seven new species and proposal of section Jani sect. nov. Mycologia: 1: 169-208.

IARC 2002. Fumonisin B1. IARC Monogr. 82: 301.

IARC 1993. Ochratoxin A. IARC Monogr. 56: 489.

Joy, M. J., Agarwal, M. K., H. Samant, H. C., Gupta, O. P., Sharma, B. M. 1980. Mycological and bacteriological studies in otomycosis. Indian J. Otolaryngol. 32: 72-75.

Karaarslan, A., Arikan, S., Ozcan, M., Ozcan, K. M. 2004. In vitro activity of terbinafine and itraconazole against Aspergillus species isolated from otomycosis. Mycoses 47: 284-287.

Kaur, R., Mittal, N., Kakkar, M., Aggarwal, A. K., Maheshwar D. M. 2000. Otomycosis: A clinicomycologic study. Ear Nose Throat J. 79: 606-609.

Kaya, A., Kiraz, N. 2007. In vitro susceptibilities of Aspergillus spp. causing otomycosis to amphotericin B, voriconazole and itraconazole. Mycoses 50: 447-450.

Kocsubé, S., Perrone, G., Magista, D., Houbraken, J., Varga, J., Szigeti, Gy., Hubka, V., Hong, S. B., Frisvad, J. C., Samson, R. A. 2016. Aspergillus is monophyletic: Evidence from multiple gene phylogenies and extrolites profiles. Stud. Mycol. 85: 199-213.

Kredics, L., Varga, J., Antal, Z., Samson, R.A., Vágvölgyi, C., Manikandan, P. 2008. Black Aspergilli in tropical infections. Rev. Med. Microbiol. 19: 65-78.

Kredics, L., Varga, J., Kocsubé, S., Revathi, R., Raghavan, A., Dóczi, I., Németh, T. M., Narendran, V., Vágvölgyi, C., Samson, R. A., Manoharan, C., Manikandan, P. 2009. Infective keratitis due to Aspergillus tubingensis. Cornea 28: 951-954.

Krogh, P. 1978. Causal associations of mycotoxic nephropathy. Acta Pathol. Microbiol. Scand. Sect. 269: 1-28. 
Krogh, P., Hald, B., Plestina, R., Ceovic, S. 1977. Balkan (endemic) nephropathy and foodborne ochratoxin A: preliminary results of a survey of foodstuff. Acta Pathol. Microbiol. 85: 238-240.

Kusters-van Someren, M. A., Samson, R. A., Visser, J. 1991. The use of RFLP analysis in classification of the black aspergilli: reinterpretation of Aspergillus niger aggregate. Curr. Genet. 19: 21-26.

Latgé, J. P. 1999. Aspergillus fumigatus and aspergillosis. Clin. Microbiol. Rev. 12: 310-350.

Lea, T., Steien, K., Stormer, C. 1989. Mechanism of ochratoxin A-induced immunosuppression. Mycopathologia 107: 153-159.

Levitz, S. M. 1989. Aspergillosis. Infect. Dis. Clin. North. Am. 3: 1-18.

Logerico, A., Ferracane, R, Haidukowsky, M., Cozzi, G., Visconti, A., Ritieni, A. 2009. Fumonisin $\mathrm{B}_{2}$ production by Aspergillus niger from grapes and natural occurence in must. Food Addit. Contam. 26: 1495-1500.

Logrieco, A., Ferracane, R., Haidukowsky, M., Cozzi, G., Visconti, A., Ritieni, A., 2009. Fumonisin B2 production by Aspergillus niger from grapes and natural occurrence in must. Food Addit. Contam. 26: 1495-1500.

Lorbeer, J. W., Tuffley, J. W., Ransom, V. E., Snover, K. L. 2002. The nature of Aspergillus niger as an endophytic fungus in onion plants and subsequent development of black mold. National Allium Research Conference, Pasco, WA, USA, Dec. 11-14 2002, Conference Abstracts pp. 20.

Löytynoja, A. 2014. Phylogeny-aware alignment with PRANK. Meth. Mol. Biol. 1079: 155170.

Lübeck, P. S., Alekhina, I. A., Lübeck, M., Bulat, S., A. 1998. UP-PCR genotyping and rDNA analysis of Ascochyta pisi. Lib. J. Phytopathol. 146: 51-55.

Mansson, M., Kleijnstrup, M. L., Phipps, R. K., Nielsen, K. F., Frisvad, J., Gotfredsen, C. H., Larsen, T. O. 2010. Isolation and NMR characterization of fumonisin $\mathrm{B}_{2}$ and a new fumonisin B6 from Aspergillus niger. J. Agricult. Food Chem. 58: 949-953. 
Marasas, W. F. O., Jaskiewicz, K., Venter, F. S., van Schalkwyk, D. J. 1988a. Fusarium moniliforme contamination of maize in esophageal cancer areas in Transkei. South Afr. Med. J. 74: 110-114.

Marasas, W. F. O., Kellerman, T. S., Gelderblom, W. C. A., Coetzer, J. A. W., Thiel, P. G., van der Lugt, J. J. 1988b. Leukoencephalomalacia in a horse induced by fumonisin B1 isolated from Fusarium moniliforme. Onderstepoort J. Vet. Res. 55: 197-203.

Marin, S., Magan, N., Ramos, A. J., Sanchis, V. 2004. Fumonisin producing strains of Fusarium: a review of their ecophysiology. J. Food Prot. 67: 1792-1805.

McNeill, J., Turland, N. J. 2011. Major changes to the Code of Nomenclature-Melbourne, July 2011. Taxon 60: 1495-1497.

Megnegneau, B., Debets, F., Hoekstra, R. F. 1993. Genetic variability and relatedness in the complex group of black aspergilli based on random amplification of polymorphic DNA. Curr. Genet. 23: 323-329.

Micheli, P. A. 1729. Nova plantarum genera. Florentiae

Mogensen, J. M., Frisvad, J. C., Thrane, U., Nielsen, K. F. 2010. Production of fumonisin B2 and B4 by Aspergillus niger on grapes and raisins. J. Agric. Food Chem. 58: 954-958.

Moore, C. B., Walls, C. M., Denning, D. W. 2001. In vitro activities of terbinafine against Aspergillus species in comparison with those of itraconazole and amphotericin B. Antimicrob. Agents Chemother. 45: 1882-1885.

Munguia, R., Daniel, S. J. Ototopical antifungals and otomycosis: a review. 2008. Int. J. Pediatr. Otorhinolaryngol. 72: 453-459.

NCCLS (2002) Reference method for broth dilution antifungal susceptibility testing of filamentous fungi. Approved standard, Document M38-A. National Committee for Clinical Laboratory Standards, Wayne, PA, USA.

Noonim, P., Mahakarnchanakul, W., Nielsen, K. F., Frisvad, J. C., Samson, R. A. 2009. Fumonisin B2 production by Aspergillus niger from Thai coffee beans. Food Addit. Contam. 26: $94-100$. 
Ogawa, H., Yoshimura, A., Sugiyama, J. 1997. Polyphyletic origins of species of the anamorphic genus Geosmithia and the relationships of the cleistothecial genera: evidence from 18S, 5S and 28S rDNA sequence analyses. Mycologia 89: 756-771.

Ozcan, K. M., Ozcan, M., Karaarslan, A., Karaarslan, F. 2003. Otomycosis in Turkey: predisposing factors, etiology and therapy. J. Laryngol. Otol. 117: 39-42.

Pagiotti, R., Angelini, P., Rubini, A., Tirillini, B., Granetti, B. 2011. Identification and characterisation of human pathogenic filamentous fungi and susceptibility to Thymus schimperi essential oil. Mycoses 54: 364-376.

Parenicova, L., Skouboe, P., Frisvad, J., Samson, R. A., Rossen, L., ten Hoor-Suykerbuyk, M., Visser, J. 2001. Combined molecular and biochemical approach identifies Aspergillus japonicus and Aspergillus aculeatus as two species. Appl. Environ. Microbiol. 67: 521-527.

Pel, H. J., de Winde, J. H., Archer, D. B., Dyer, P. S., Hofmann, G., Schaap, P. J., Turner, G., de Vries, R. P., Albang, R., Albermann, K., Andersen, M. R., Bendtsen, J. D., Benen, J. A. E., van den Berg, M., Breestraat, S., Caddick, M. X., Contreras, R., Cornell, M., Coutinho, P. M., Danchin, E. G. J., Debets, A. J. M., Dekker, P., van Dijck, P. W. M., van Dijk, A., Dijkhuizen, L., Driessen, A. J. M., d'Enfert, C., Geysens, S., Goosen, C., Groot, G. S. P., de Groot, P. W. J., Guillemette, T., Henrissat, B., Herweijer, M., van den Hombergh, J. P. T. W., van den Hondel, C. A. M. J., van der Heijden, R. T. J. M., van der Kaaij, R. M., Klis, F. M., Kools, H. J., Kubicek, C. P., van Kuyk, P. A., Lauber, J., Lu, X., van der Maarel, M. J. E. C., Meulenberg, R., Menke, H., Mortimer, M. A., Nielsen, J., Oliver, S. G., Olsthoorn, M., Pal, K., van Peij, N. N. M. E., Ram, A. F. J., Rinas, U., Roubos, J. A., Sagt, C. M. J., Schmoll, M., Sun, J. B., Ussery, D., Varga, J., Vervecken, W., de Vondervoort, P. J. J. V.,Wedler, H.,Wösten, H. A. B., Zeng, A. P., van Ooyen, A. J. J., Visser, J., Stam, H. 2007. Genome sequencing and analysis of the versatile cell factory Aspergillus niger CBS 513.88. Nat. Biotechnol. 25: 221231.

Perrone, G., Stea, G., Epifani, F., Varga, J., Frisvad, J. C., Samson, R. A. 2011. Aspergillus niger contains the cryptic phylogenetic species A. awamori. Fungal Biol. 115: 1138-1150.

Perrone, G., Susca, A., Epifani, F., Mule, G. 2006. AFLP characterization of Southern Europe population of Aspergillus Section Nigri from grapes. Int. J. Food Microbiol. 111: 22-27.

Perrone, G., Varga, J., Susca, A., Frisvad, J. C., Stea, G., Kocsubé, S., Tóth, B., Kozakiewicz, Z., Samson, R. A., 2008. Aspergillus uvarum sp. nov., an uniseriate black Aspergillus species isolated from grapes in Europe. Int. J. Syst. Evol. Microbiol. 58: 1032-1039. 
Peterson, S. W. 1995. Phylogenetic analysis of Aspergillus sections Cremei and Wentii, based on ribosomal DNA sequences. Mycol. Res. 99: 1349-1355.

Peterson, S. W. 2000. Phylogenetic relationships in Aspergillus based on rDNA sequence analysis. In: Samson, R. A., Pitt, J. I. (szerk.) Integration of modern taxonomic methods for Penicillium and Aspergillus classification. pp. 323-355. Harwood Academic Publishers, Amsterdam.

Peterson, S. W. 2008. Phylogenetic analyses of Aspergillus species using DNA sequences from four loci. Mycologia 100: 205-226.

Peterson, S. W., Varga, J., Frisvad, J. C. 2008. Phylogeny and subgeneric taxonomy of Aspergillus. In: Varga, J., Samson, R. A. (szerk.) Aspergillus in the genomic era. pp. 33-56. Academic Publishers, Wageningen.

Pitt, J. I., Hocking, A. D. 1997. Fungi and food spoilage. 2nd ed.; Blackie Academic and Professional: London, U.K.

Pitt, J. I., Samson, R. A., Frisvad, J. C. 2000. List of accepted species and their synonyms in the family Trichocomaceae. In: Samson, R. A., Pitt, J. I. (szerk.) Integration of modern taxonomic methods for Penicillium and Aspergillus classification. pp. 9-79. Harwood Academic Publishers, Amsterdam.

Pitt, J. I., Taylor, J. W. 2016. Proposal to conserve the name Aspergillus (Fungi: Eurotiales: Trichocomaceae) with a conserved type to maintain also the name Eurotium. Taxon 65: 631632.

Pollastro, S., De Miccolis, R. M., Faretta, F. 2006. A new semi-selective medium for the ochratoxigenic fungus Aspergillus carbonarius. J. Plant Pathol. 88: 107-112.

Proctor, R. H., Brown, D. W., Plattner, R. D., Desjardins, A. E. 2003. Co-expression of 15 contiguous genes delineates a fumonisin biosynthetic gene cluster in Gibberella moniliformis. Fungal Genet. Biol. 38: 237-249.

Rank, C., Nielsen, K. F., Larsen, T. O., Varga, J., Samson, R. A., Frisvad, J. C. 2011. Distribution of sterigmatocystin in filamentous fungi. Fungal Biol. 115: 406-420.

Raper, K. B., Fennell, D. I. 1965. The genus Aspergillus. Williams \& Wilkins, Baltimore 
Ronquist, F., Teslenko, M., van der Mark, P., Ayres, D. L., Darling, A., Höhna, S., Larget, B., Liu, L., Suchard, M. A., Huelsenbeck, J. P. 2012. MrBayes 3.2: Efficient Bayesian phylogenetic inference and model choice across a large model space. Syst. Biol. 61: 539-542.

Saitou N., Nei M. 1987. The neighbor-joining method: a new method for reconstructing phylogenetic trees. Mol. Biol. Evol. 4: 406-425.

Samson, R. A., Hoekstra, E. S., Frisvad, J.C. 2004. Introduction to Food- and Airborne Fungi. 7th ed.; Centraalbureau voor Schimmelcultures, Utrecht, The Netherlands.

Samson, R. A., Noonim, P., Meijer, M., Houbraken, J., Frisvad, J. C., Varga, J. 2007. Diagnostic tools to identify black aspergilli. Stud. Mycol. 59: 129-145.

Samson, R. A., Varga, J. 2009. What is a species in Aspergillus? Med. Mycol. 47: 13-20.

Samson, R. A., Visagie, C. M., Houbraken, J., Hong, S. B., Hubka, V., Klaassen, C. H. W., Perrone, G., Seifert, K. A., Susca, A., Tanney, J. B., Varga, J., Kocsubé, S., Szigeti, Gy., Yaguchi, T., Frisvad, J. C. 2014. Phylogeny, identification and nomenclature of the genus Aspergillus. Stud. Mycol. 78: 141-173.

Samson, R. A., Hubka, V., Varga, J., Houbraken, J., Hong, S. B., Klaassen, C. H. W., Perrone, G., Seifert, K. A., Magista, D., Visagie, C. M., Kocsubé, S., Szigeti, Gy., Yaguchi, T., Peterson, S. W., Frisvad, J. C. 2017. Conversation of Aspergillus with A. niger as the conserved type is unnecessary and potentially disruptive. Taxon 66: 1439-1446.

Schoch, C. L., Seifert, K. A., Huhndorf, S., Robert, V., Spouge, J. L., Levesque, C. A., Chen, W., Fungal Barcoding Consortium 2012. Nuclear ribosomal internal transcribed spacer (ITS) region as a universal DNA barcode marker for Fungi. Proc. Natl. Acad. Sci. U. S. A. 109: 62416246.

Seefelder, W., Gossmann, M., Humpf, H. U. 2002. Analysis of fumonisin B1 in Fusarium proliferatum-infected asparagus spears and garlic bulbs from Germany by liquid chromatography-electrospray ionization mass spectrometry. J. Agric. Food Chem. 50: 27782781 .

Silvestro, D., Michalak, I. 2012. raxmlGUI: a graphical front-end for RAxML. Organ. Divers. Evol. 12: 335-345. 
Sklenar, F., Jurjevic, Z., Zalar, P., et al. (2017). Phylogeny of osmophillic aspergilli (subgenus Aspergillus) and taxonomic revision of section Restricti. Studies in Mycology.

Smith, J. E., Moss, M. O. 1985. Mycotoxins. Formation, analysis and significance. John Wiley and Sons, Chichester, England.

Stockmann-Juvala, H., Savolainen, K. 2008. A review of the toxic effects and mechanisms of action of fumonisin B1. Hum. Exp. Toxicol. 27: 799-809.

Stolk, A. C., Malla. D. S. 1971. Penicillium inflatum sp. nov. Persoonia 6: 197-200.

Szécsi, Á., Szekeres, A., Bartók, T., Oros, G., Bartók, M., Mesterházy, Á., 2010. Fumonisin B1-4-producing capacity of Hungarian Fusarium verticillioides isolates. World Mycotoxin J. 3: 67-76.

Tamura, K., Dudley, J., Nei, M., Kumar, S. 2007. MEGA4: Molecular Evolutionary Genetics Analysis (MEGA) software version 4.0. Mol. Biol. Evol. 24: 1596-1599.

Tamura, M., Kawahara, K., Sugiyama, J. 2000. Molecular phylogeny of Aspergillus and associated teleomorphs in the Trichocomaceae (Eurotiales). In: Samson, R. A., Pitt, J. I. (szerk.) Integration of modern taxonomic methods for Penicillium and Aspergillus classification. pp. 357-372. Harwood Academic Publishers, Amsterdam.

Taylor, J. W. 2011. One Fungus = One Name: DNA and fungal nomenclature twenty years after PCR. IMA Fungus 2: 113-120.

Taylor, J. W., Göker, M., Pitt, J. I. 2016. Choosing one name for pleomorphic fungi: The example of Aspergillus versus Eurotium, Neosartorya and Emericella. Taxon 65: 593-601.

Téren, J., Varga, J., Hamari, Zs., Rinyu, E., Kevei, F. 1996. Immunochemical detection of ochratoxin A in black Aspergillus strains. Mycopathologia 174: 171-176.

Thom, C., Raper, K. B. 1945. A manual of the Aspergilli. The Williams \& Wilkins Company, Baltimore.

Tyson, J. L., Fullerton, R. A. 2004. Effect of soil-borne inoculum on incidence of onion black mould (Aspergillus niger). New Zeal. Plant Prot. 57: 138-141. 
Udagawa, S., Uchiyama, S. 2002. Neocarpenteles: a new ascomycete genus to accommodate Hemicarpenteles acanthosporus. Mycoscience 43: 3-6.

Vaidya, G., Lohman, D. J., Meier, R. 2011. SequenceMatrix: concatenation software for the fast assembly of multi-gene datasets with character set and codon information. Cladistics 27: 171-180.

van der Merwe, K. J., Stein, P. S., Fourie, L., Scott, D. B., Theron, J. J. 1965. Ochratoxin A, a toxic metabolite produced by Aspergillus ochraceus Wilh. Nature 205: 1112-1113.

Varga, J., Frisvad, J. C., Samson, R. A. 2010. New and revisiting species in Aspergillus section Nigri. Stud. Mycol. 69: 1-17.

Varga, J., Houbraken, J., Samson, R. A., Frisvad, J. C. 2008. Molecular diversity of Aspergillus and Penicillium species on fruits and vegetables. In: Barkai-Golan, B., Paster, N. (szerk.) Mycotoxins in fruits and vegetables. pp. 205-223 Academic Press.

Varga, J., Juhász, ., Kevei, F., Kozakiewicz, Z. 2004. Molecular diversity of agriculturally important Aspergillus species. Eur. J. Plant Pathol. 110: 627-640.

Varga, J., Kevei, F., Debets, F., Kozakiewicz, Z., Croft, J. H. 1994. Mitochondrial DNA restriction fragment length polymorphisms in field isolates of the Aspergillus niger aggregate. Can. J. Microbiol. 40: 612-621.

Varga, J., Kevei, F., Fekete, C., Coenen, A., Kozakiewicz, Z., Croft, J. H. 1993. Restriction fragment length polymorphisms in the mitochondrial DNAs of the Aspergillus niger aggregate. Mycol. Res. 97: 1207-1212.

Varga, J., Kevei, F., Hamari, Z., Tóth, B., Téren, J., Croft, J. H., Kozakiewicz, Z. 2000. Genotypic and phenotypic variability among black aspergilli. In: Samson, R. A., Pitt, J. I. (szerk.) Integration of modern taxonomic methods for Penicillium and Aspergillus classification. pp. 397-411. Harwood Academic Publishers, Amsterdam.

Varga, J., Kocsubé, S., Péteri, Z., Samson, R.A. 2009a. An overview of ochratoxin research. In: Rai, M., Bridge, P. (szerk.) Applied Mycology, pp. 38-55. CABI Publishers. 
Varga, J., Kocsubé, S., Suri, K., Szigeti, Gy., Szekeres, A., Varga, M., Tóth, B., Bartók, T. 2010. Fumonisin contamination and fumonisin producing black Aspergilli in dried vine fruits of different origin. Int. J. Food Microbiol. 143: 143-149.

Varga, J., Kocsubé, S., Szigeti, Gy., Mán, V., Tóth, B., Vágvölgyi, Cs., Bartók, T. 2012. Black Aspergilli and fumonisin contamination in onions purchased in Hungary. Acta Aliment. 41: 414423.

Varga, J., Kocsubé, S., Tóth, B., Frisvad, J. C., Perrone, G., Susca, A., Meijer, M., Samson, R. A. 2007. Aspergillus brasiliensis sp. nov., a biseriate black Aspergillus species with world-wide distribution. Int. J. Syst. Evol. Microbiol. 57: 1925-1932.

Varga, J., Téren, J., Rigó, K., Tóth, B., Kocsubé, S. 2009b. Gombák másodlagos anyagcseretermékei: mikotoxinok, gombamérgek. JATE Press, Szeged

Vennewald, I., Klemm, E., Otomycosis: diagnosis and treatment. 2010. Clin. Dermatol. 28: 202-211.

Visagie, C. M., Houbraken, J., Frisvad, J. C., Hong, S. B., Klaassen, C. H. W., Perrone, G., Seifert, K. A., Varga, J., Yaguchi, T., Samson, R. A. 2014a. Identification and nomenclature of the genus Penicillium. Stud. Mycol. 78: 343-371.

Visagie, C. M., Varga, J., Houbraken, J., Meijer, M., Kocsubé, S., Yilmaz, N., Fotedar, R., Seifert, K. A., Frisvad, J. C., Samson, R. A. 2014b. Ochratoxin production and taxonomy of the yellow aspergilli (Aspergillus section Circumdati). Stud. Mycol. 78: 1-61.

von Haller, A. 1768. Historia stripium indigenarum Helvetiae inchoata. Bernae: Sumptibus Societatis typographicae (ex officina Dan. Brunneri \& Alb. Halleri)

Walker, J. C., Lindegren, C. C. 1924. Further studies on the relation of onion scale pigmentation to disease resistance. J. Agric. Res. 29: 507-514.

Wang, E., Norred, W. P., Bacon, C. W., Riley, R. T., Merrill, A. H. 1991. Inhibition of sphingolipid biosynthesis by fumonisins. Implications for dieases associated with Fusarium moniliforme. J. Biol. Chem. 266: 14486-14490. 
Yenisehirli, G., Bulut, Y., Guven, M., Gunday, E. 2009. In vitro activities of fluconazole, itraconazole and voriconazole against otomycotic fungal pathogens. J. Laryng. Otol. 123: 978981.

Yokoyama, K., Wang, L., Miyaji, M., Nishimura, K. 2001. Identification, classification and phylogeny of the Aspergillus section Nigri inferred from mitochondrial cytochrome b gene. FEMS Microbiol. Lett. 200: 241-246.

Yoshizawa, T., Yamashita, A., Luo, Y. 1994. Fumonisin occurrence in corn from high-risk and low risk areas for human esophageal cancer in China. Appl. Environ. Microbiol. 60: 1626-1629.

Zarei, M. A., Masoomi, S. A., Mohammadi, H. 2010. Clinical and mycological studies of otomycosis. Pak. J. Med. Sci. 26: 187-190. 


\section{Köszönetnyilvánítás}

Köszönettel tartozom mindenekelőtt Prof. Dr. Varga Jánosnak, témavezetőmnek, hogy betekintést nyerhettem ennek a szakterületnek a rejtelmeibe, amelynek ő igen jeles képviselője volt. Széleskörü szaktudásával, emberi hozzáállásával folyamatosan segítségemre volt, és egyengette utamat.

Köszönöm Prof. Dr. Vágvölgyi Csabának, hogy Ph. D. munkámat az általa vezetett tanszéken végezhettem, és részese lehettem egy szakmailag igényes munkaközösségnek.

Köszönöm Dr. Kocsubé Sándornak, hogy már szakdolgozó koromtól folyamatosan segítette a munkámat, mind elméleti, mind gyakorlati vonatkozásban. Rengeteg praktikát, logikus laboratóriumi gondolkodásmódot tanulhattam tőle, amiért nagyon hálás vagyok.

Hálával tartozom Prof. Dr. Robert A. Samson-nak és Dr. Jos Houbraken-nek, hogy a filogenetikai vizsgálatokhoz szükséges laboratóriumi munkát a CBS Gombakutató Központban, Utrechtben végezhettem. Köszönöm, hogy mind anyagi, mind szakmai értelemben segítették a munkámat, és a szükséges törzsekhez hozzáférést biztosítottak számomra.

Köszönöm Dr. Baranyi Nikolettnek, Ph. D.-hallgató társamnak, hogy gyakorlati vonatkozásban segítette a munkámat.

Köszönetemet szeretném kifejezni Suri Katalinnak, Horányi Adriennek és Mán Viktóriának, kutatócsoportunk korábbi szakdolgozóinak, akik munkájukkal hozzájárultak ahhoz, hogy ez a disszertáció létrejöhessen.

Dr. Bartók Tibornak, Dr. Szekeres Andrásnak és Dr. Bencsik Ottónak köszönöm a HPLC-mérések során nyújtott nélkülözhetetlen segítséget.

Köszönöm a 309-es labor és a tanszék minden munkatársának, hogy segítőkész hozzáállásukkal támogatták munkám haladását.

Köszönettel tartozom Szüleimnek, akik mindvégig támogattak tanulmányaimban.

Szeretném megköszönni férjemnek, Petkovits Tamásnak, hogy türelmesen kitartott mellettem, és erőt adott a disszertáció elkészítése során. 
A dolgozattal kapcsolatos kutatásokat az „Új utak a természetes anyag alapú gyógyszerkutatásban: Rendszermetabolomikai megközelítések növényi és mikrobiális eredetü bioaktív terpenoidok felkutatására.” címü, GINOP-2.3.2-15-2016-00012 számú projekt támogatta. Az infrastrukturális hátteret a GINOP-2.3.3-15-2016-00006 számú, „Mikrobiális génbankoz kapcsolódó integrált élettudományi és hatóanyag kutatás-fejlesztési centrum” címü pályázat biztosította. 